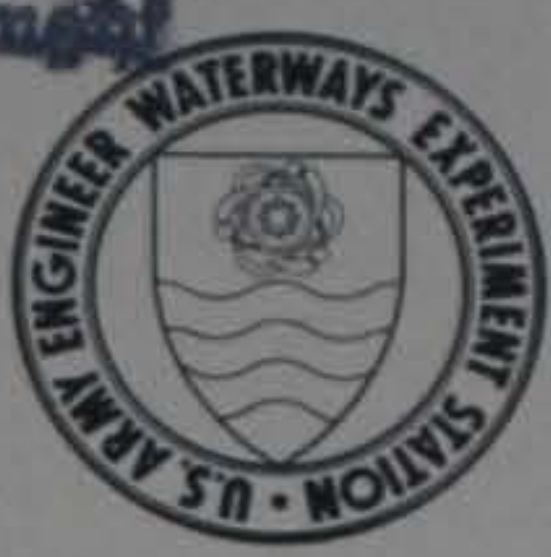

MISCELLANEOUS PAPER SL-82-12

\title{
OPTIMIZATION OF HIGH-STRENGTH CONCRETE MIXTURE PROPORTIONS FOR THE ANMCC IMPROVEMENT PROJECT
}

by

Anthony A. Bombich, A. Dale Magoun

Structures Laboratory

U. S. Army Engineer Waterways Experiment Station

P. O. Box 631, Vicksburg, Miss. 39180

August 1982

Final Report

Approved For Public Release; Distribution Unlimited

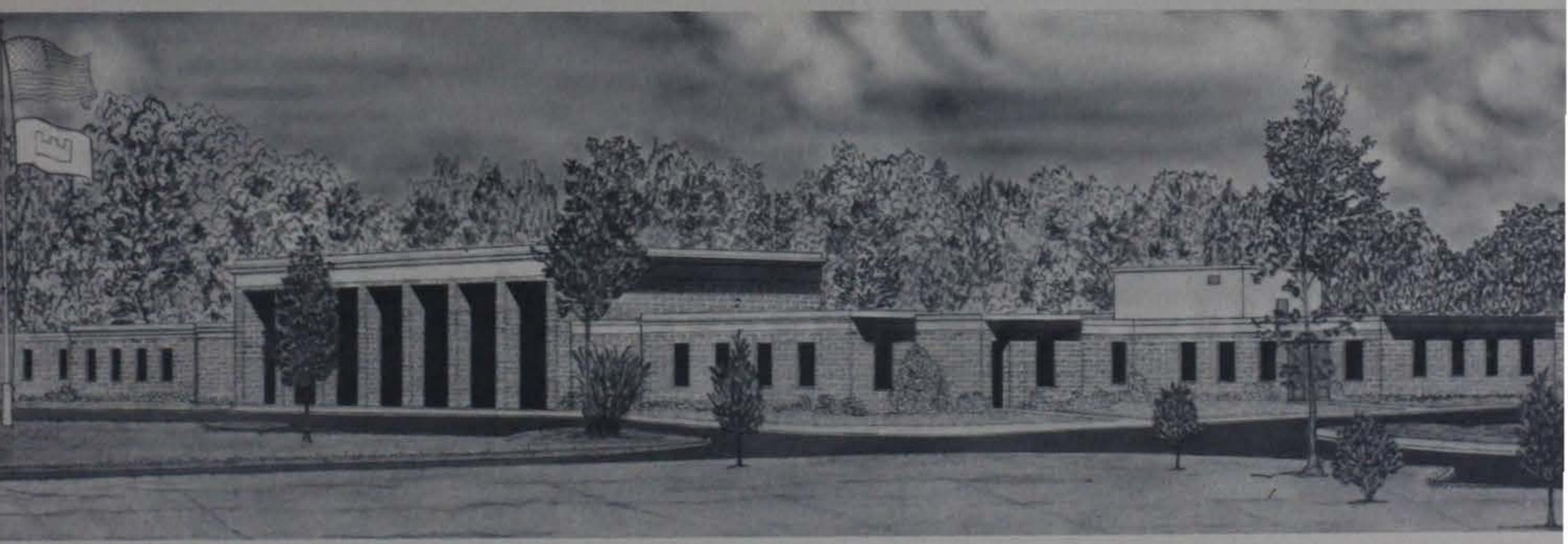

Prepared for U. S. Army Engineer District, Omaha Omaha, Nebr. 68102 


\begin{tabular}{|c|c|}
\hline REPORT DOCUMENTATION PAGE & $\begin{array}{c}\text { READ INSTRUCTIONS } \\
\text { BEFORE COMPLETING FORM }\end{array}$ \\
\hline $\begin{array}{l}\text { 1. REPORT NUMBER } \\
\text { Miscellaneous Paper SL-82-12 }\end{array}$ & 3. RECIPIENT'S CATALOG NUMBER \\
\hline \multirow{2}{*}{$\begin{array}{l}\text { 4. TITLE (and Subttio) } \\
\text { OPTIMIZATION OF HIGH-STRENGTH CONCRETE MIXTURE } \\
\text { PROPORTIONS FOR THE ANMCC IMPROVEMENT PROJECT }\end{array}$} & $\begin{array}{l}\text { 5. TYPE OF REPORT \& PERIOD COVERED } \\
\text { Final report }\end{array}$ \\
\hline & 6. PERFORMING ORG. REPORT NUMBER \\
\hline $\begin{array}{l}\text { 7. AUTHOR(a) } \\
\text { Anthony A. Bombich } \\
\text { A. Dale Magoun }\end{array}$ & 8. CONTRACT OR GRANT NUMBER(v) \\
\hline $\begin{array}{l}\text { 9. PERFORMING ORGANIZATION NAME AND ADDRESS } \\
\text { U. S. Army Engineer Waterways Experiment Station } \\
\text { Structures Laboratory } \\
\text { P. O. BOX } 631 \text {, Vicksburg, Miss. } 39180\end{array}$ & $\begin{array}{l}\text { 10. PROGRAM ELEMENT, PROJECT, TASK } \\
\text { AREA \& WORK UNIT' NUMBERS }\end{array}$ \\
\hline \multirow{2}{*}{$\begin{array}{l}\text { 11. CONTROLLING OFFICE NAME AND ADDRESS } \\
\text { U. S. Army Engineer District, Omaha } \\
\text { Omaha, Nebr. } 68102\end{array}$} & $\begin{array}{r}\text { 12. REPORT DATE } \\
\text { August } 1982 \\
\end{array}$ \\
\hline & $\begin{array}{l}\text { 13. NUMBER OF PAGES } \\
112\end{array}$ \\
\hline \multirow[t]{2}{*}{ 14. MONITORING AGENCY NAME \& ADDRESS(if different from Controlline Office) } & $\begin{array}{l}\text { 15. SECURITY CLASS. (of thio roport) } \\
\text { Unclassified }\end{array}$ \\
\hline & $\begin{array}{l}\text { 15a. DECLASSIFICATION/DOWNGRADING } \\
\text { SCHEDULE }\end{array}$ \\
\hline
\end{tabular}

Approved for public release; distribution unlimited.

17. DISTRIBUTION STATEMENT (of the abstract entered in Block 20, if different from Report)

18. SUPPLEMENTARY NOTES

Available from National Technical Information Service, 5285 Port Royal Road, Springfield, Va. 22151.

This is CTIAC Report No. 58.

19. KEY WORDS (Continue on reverse side If necessary and ldentify by block number)

ANMCC Improvement Project

High strength concrete

Nuclear weapons effects

Strength of materials

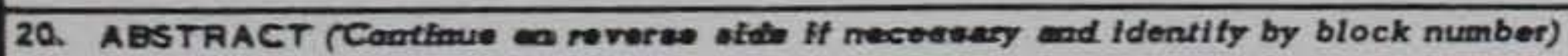

High-strength concrete mixtures were proportioned and tested in order to achieve compressive strengths in excess of 9,000 psi at 1 year of age and 11,000 psi at 2 years of age. These mixtures were proportioned to minimize total heat generation when used during construction of the Alternate National Military Command Center (ANMCC). Minimization of heat generation, especially that occurring at early ages, serves to minimize thermal strains occurring in the concrete cavity liners.

(Continued) 


\section{ABSTRACT (Continued).}

The study was conducted in two phases. In Phase I a matrix of 28 highstrength concrete mixtures was evaluated to isolate concrete mixtures which best met the specified criteria. Mixtures contained several levels of water reduction, cement contents, and pozzolan (fly ash) replacement of cement. Steel fibers were also used. Curing was done at $73 \mathrm{~F}$ and $122 \mathrm{~F}$ in sealed and immersed condition. The study indicated that all mixtures containing pozzolan failed to gain appreciable strength after 28 days age when cured at $122 \mathrm{~F}$. This was the appropriate curing temperature which would exist in ANMCC concrete liners. The optimum mixture chosen contained $658 \mathrm{lb}$ of Type V cement, with no pozzolan replacement, and contained high-range water-reducing admixtures. Water-cement ratio by weight was 0.364 . Statistical analyses performed on Phase I test results appear as appendices.

Phase II included tests on the mixture chosen as optimum from Phase I. Included were tests to determine thermal and mechanical properties on concrete specimens cured at $73 \mathrm{~F}$ and $122 \mathrm{~F}$ in sealed condition. The data obtained from Phase II tests were used in computer thermal studies for the ANMCC. 
A program to optimize the high strength mixture proportions and to determine the mechanical and thermal properties of a selected mixture for the Alternate National Military Command Center (ANMCC) Improvement Project was authorized by DA Form 2544, Intra-Army Order for Reimbursable Services, No. MIL 3131, dated 5 July 1978, from the U. S. Army Engineer District, Omaha.

The work reported herein was conducted between October 1978 and March 1982 at the Structures Laboratory of the U. S. Army Engineer Waterways Experiment Station (WES) under the direction of Mr. Bryant Mather, Mrs. Katharine Mather, and Mr. John Scanlon, by or under the supervision of Messrs. Billy R. Sullivan, James E. McDonald, Kenneth L. Saucier, William G. Miller, and Ronald E. Reinhold. Mr. Saucier assisted in project planning and was the project consultant. Mr. Anthony A. Bombich was project leader and prepared this report. Statistical analyses were performed by A. D. Magoun of Applied Research and Analysis, Inc.

Funds for publication of the report were provided from those made available for operation of the Concrete Technology Information Analysis Center (CTIAC). This is CTIAC Report No. 58.

Commanders and Directors of WES during conduct of this study and preparation of this report were COL John L. Cannon, CE, COL Nelson P. Conover, CE, and COL Tilford C. Creel, CE. Mr. F. R. Brown was Technical Director. 
PREFACE

CONVERSION FACTORS, NON-SI TO METRIC (SI) UNITS

OF MEASUREMENT.

PART I: INTRODUCTION .. . . . . . . . . . . . . . . . 5

Background. . . . . . . . . . . . . . . . . 5

Purpose and Scope... . . . . . . . . . . . . . . 6

PART II: CONCRETE MIXTURES AND MATERIALS . . . . . . . . . . . . 8

Concrete Mixture Materials. . . . . . . . . . . . 8

Cement. . . . . . . . . . . . . . . . . 8

Pozzolan (Fly Ash)..................... . 9

Coarse Aggregate. . . . . . . . . . . . . . . . . 9

Fine Aggregate. . . . . . . . . . . . . . . . . 10

Water-Reducing Admixtures . . . . . . . . . . . . . 11

Steel Fibers. . . . . . . . . . . . . . . . . . 11

Mixture Design Considerations . . . . . . . . . . . . 12

PART III: CONCRETE TESTING . . . . . . . . . . . . . . . 14

Specimen Curing Conditions. . . . . . . . . . . . . . . 14

Specimen Proportions. . . . . . . . . . . . . . 15

Tests and Procedures. . . . . . . . . . . . . . . 16

Compressive Strength, Modulus of Elasticity, and

Poisson's Ratio.................... 16

Flexural Strength (Modulus of Rupture) and Tensile

Strain Capacity .................... 17

Thermal Diffusion, Specific Heat, and Thermal

Conductivity. . . . . . . . . . . . . . . . 18

Adiabatic Temperature Rise. . . . . . . . . . . . 18

Coefficient of Thermal Expansion. . . . . . . . . . . 18

PART IV: TEST RESUlTS. . . . . . . . . . . . . . . . . 19

Phase I Tests . . . . . . . . . . . . . . . . . . 19

Compressive Strength. . . . . . . . . . . . . . 19

Flexural Strength...................... 23

Phase II Tests. . . . . . . . . . . . . . . . . . 23

PART V: REVIEW AND RECOMMENDATIONS . . . . . . . . . . . . . 26

Phase I... . . . . . . . . . . . . . . . . 26

Phase II. . . . . . . . . . . . . . . . . . . . 28

High-Strength Concrete Placement Guidelines . . . . . . . . . 28

REFERENCES. . . . . . . . . . . . . . . . . 30

TABLES $1-17$

FIGURES $1-18$ 


\section{CONTENTS (Continued)}

Page

APPENDIX A: EXPERIMENT I, EVALUATIONS OF COMPRESSIVE STRENGTH

GAIN OF PHASE I CONCRETE MIXTURES BY AGE WITH

RESPECT TO WATER-REDUCING ADMIXTURES, CURING TEM-

PERATURES, AND POZZOLAN REPLACEMENT FOR A SINGLE

CEMENTITIOUS MATERIALS CONTENT BY SOLID VOLUME . . . A1

APPENDIX B: EXPERIMENT II, EVALUATIONS OF COMPRESSIVE

STRENGTH GAINS OF PHASE I CONCRETE MIXTURES BY

AGE WITH RESPECT TO VARYING SOLID VOLUMES OF

CEMENTITIOUS MATERIALS, CURING METHOD, CURING

TEMPERATURE, AND POZZOLAN REPLACEMENT. . . . . . . B1

APPENDIX C: EXPERIMENT III, MATHEMATICAL MODELING OF COM-

PRESSIVE STRENGTHS GAINS OF PHASE I CONCRETE

MIXTURES WITH RESPECT TO WATER/CEMENTITIOUS

MATERIALS RATIO, SOLID VOLUMES OF CEMENTITIOUS

MATERIALS CONTENT, AND AGE . . . . . . . . . .

C1 
Non-SI units of measurement used in this report can be converted to metric (SI) units as follows:

\begin{tabular}{|c|c|c|}
\hline Multiply & By & To Obtain \\
\hline inches & 25.4 & millimetres \\
\hline feet & 0.3048 & metres \\
\hline cubic feet & 0.02831685 & cubic metres \\
\hline cubic yards & 0.7645549 & cubic metres \\
\hline ounce (U. S. fluid) & 0.0000295735 & cubic metres \\
\hline pounds (mass) & 0.4535924 & kilograms \\
\hline pounds (force) & 4.448222 & newtons \\
\hline $\begin{array}{l}\text { pounds (force) per square } \\
\text { inch }\end{array}$ & 6894.757 & pascals \\
\hline $\begin{array}{l}\text { pounds (force) per square } \\
\text { inch per minute }\end{array}$ & 114.91267 & pascals per second \\
\hline $\begin{array}{l}\text { pounds (mass) per } \\
\text { cubic foot }\end{array}$ & 16.01846 & $\begin{array}{l}\text { kilograms per } \\
\text { cubic metre }\end{array}$ \\
\hline $\begin{array}{l}\text { pounds (mass) per } \\
\text { cubic yard }\end{array}$ & 0.05933 & $\begin{array}{l}\text { kilograms per } \\
\text { cubic metre }\end{array}$ \\
\hline square foot per hour & 0.0000258064 & $\begin{array}{l}\text { square metres per } \\
\text { second }\end{array}$ \\
\hline $\begin{array}{l}\text { calorie (International } \\
\text { Table) per gram }\end{array}$ & 4186.80 & joules per kilogram \\
\hline Fahrenheit degrees & $5 / 9$ & $\begin{array}{l}\text { Celsius degrees or } \\
\text { Kelvins* }\end{array}$ \\
\hline $\begin{array}{l}\text { Btu (International Table) } \\
\text { per pound (mass) } \cdot \text { degree } \\
\text { Fahrenheit }\end{array}$ & 4186.8 & $\begin{array}{l}\text { joules per kilogram } \\
\text { Kelvin }\end{array}$ \\
\hline $\begin{array}{l}\text { Btu (International Table) } \\
\text { foot per hour } \\
\text { degree Fahrenheit }\end{array}$ & 0.01201899 & $\begin{array}{l}\text { watts per metre } \\
\text { Kelvin }\end{array}$ \\
\hline $\begin{array}{l}\text { inches per inch per degree } \\
\text { Fahrenheit }\end{array}$ & $5 / 9$ & $\begin{array}{l}\text { metres per metre } \\
\text { per Kelvin }\end{array}$ \\
\hline
\end{tabular}




\section{PART I: INTRODUCTION}

\section{Background}

1. The Alternate National Military Command Center (ANMCC) Improvement Project or Alternate National Improvement Project (ANIP), proposed to be located near Fort Ritchie, Maryland, is being designed to withstand the effects of nuclear weapons. High-strength concrete will be used for cavity linings. Originally, specifications called for compressive strengths greater than or equal to 6000 psi at 28-days age. Subsequently, the strength requirements were changed. An investigation was conducted for the ANMCC Improvement Project ${ }^{1}$ to determine heat gains in the cavity workspace resulting from hydration of cement in concrete and backpacking. The ANMCC thermal study showed that early-age generation of heat needed to be minimized to reduce cavity heat gains and subsequent cooling requirements necessary to maintain acceptable temperature levels in the workspace environment of the project during construction.

2. Prior investigations ${ }^{2,3}$ indicated that ultimate strength of concrete was reduced when cured above standard curing temperatures. It was determined in the ANMCC thermal study that concrete temperatures would exist in the range of 80 to $130 \mathrm{~F}$ in the cavity liner soon after placement.

3. Since the facility would not be operational for at least 2-1/2 years after placement of the concrete liner was completed, only sufficient strength to permit form stripping and subsequent lift placement at 2- to 3-days age was required. This requirement permitted selection of a low- or moderate-heat cement with possible pozzolan replacement to produce lower early-age heat production and maximize ultimate strength. Compressive strength requirements were increased to minimize cavity liner thicknesses. 
4. The purpose of this study was to make a preliminary selection of proportions for concrete mixtures and determine concrete properties for use in designing and constructing cavity linings of the ANIP. High compressive strengths, in excess of 9,000 psi at 1 -year age $\left(f_{c}^{\prime} \geq\right.$ 9,000 psi at 1 year), and in excess of 11,000 psi at 2-years age ( $f_{c}^{\prime} \geq$ 11,000 psi at 2 years) were considered desirable to achieve maximum savings in excavation and concrete lining construction costs. Mixture proportions were to provide proper consistency and adequate workability for concrete placement under the conditions to be employed during construction of the ANIP cavity linings. Consistent with high compressive strength and adequate workability, the mixtures were to be proportioned to minimize total heat generation during construction due to heat of hydration of cement, to minimize the development of thermal strains in cavity linings, and to maximize the flexural strength and toughness of the concrete.

5. The study was conducted in two phases. The objective of Phase I was to isolate concrete mixtures which best meet the specified criteria. The objective of Phase II was the determination of additional properties on the optimum mixture selected from Phase I. The data from Phase II were used as input to additional computer simulations for the ANMCC thermal study in which the extent of thermal stress problems in concrete cavity linings was examined.

6. Mixtures in Phase I contained several levels of water reduction, cement contents, and pozzolan replacement of cement. Some mixtures also contained steel fibers. Concrete specimens were cured at two storage temperatures and in sealed and immersed condition. Tests conducted in Phase II on specimens cast from the optimum mixture selected from Phase I and cured at two storage temperatures provided thermal and mechanical properties necessary to conduct computer thermal studies of the concrete.

7. To further analyze and interpret Phase I test results, experiments were performed using valid statistical procedures to investigate 
the data. These experiments were completed after this report was completed. The results of the experiments are thus presented as Appendices $A, B$, and C. These results are thought to be especially appropriate for facilities such as ANIP where probabilistic design methodology may be used. 
8. In Phase I a matrix of concrete mixtures was developed consisting of 28 mixtures shown in Table 1 from which the optimum mixture would be selected for Phase II. These mixtures included variables such as four cement contents, four pozzolan replacement percentages, two water-reducing admixtures, and inclusion of steel fibers. Air entrainment was not used in any of the mixtures. Pozzolan replacement was incorporated to reduce heat of hydration. The steel fibers were incorporated in an attempt to promote higher flexural strengths, thus permit thinner cavity liners. Mixtures were proportioned to obtain minimum water-cement ratios while maintaining adequate workability (2-1/2- to 3-in. slump). Changes in concrete materials used in the mixtures plus requested additional check-out mixtures resulted in the preparation and testing of five supplemental mixtures. Table 2 contains mixture proportion data for all mixtures in this investigation.

\section{Concrete Mixture Materials}

9. The selection of materials was based upon obtaining the best materials to meet the governing criteria from a location as close to the Fort Ritchie, Maryland, area as possible. Some difficulty did arise in locating a source of low- to moderate-heat cement in the Eastern U. S. Cement

10. Type $\mathrm{V}$ cement was located by Omaha District from a source in Catskill, New York. Type IV was originally sought; however, even Type II with heat of hydration limit was unavailable. The cement was received in two separate shipments. The second shipment, RC-822(2), was necessary when a portion of the first shipment, RC-822, was accidentally contaminated during storage preparation at WES. RC-822(2), although of the same chemical analysis, was ground finer than RC-822. Samples of the cement were analyzed and found to meet the requirements of ASTM C $150-77^{4}$ for Type $\mathrm{V}$ cement. Results of the analyses are found in Table 3 . A11 concrete in Phase I was proportioned with cement RC-822 except that for 
mixtures 20 and $24 \mathrm{~S}$. These mixtures plus all of the concrete proportioned for Phase II contained cement RC-822(2). One concrete mixture (No. 17) made originally with cement RC-822 was repeated with cement RC-822(2) and called No. 17A for evaluation of the differences in strength gain between the cements. Comparative compressive strength gains for the two mixtures are shown in Figure 1.

11. Supplemental heat of hydration tests were conducted to assess the effects of storage temperature in general accordance with ASTM C 186-78, 4 "Standard Test Method for Heat of Hydration of Hydraulic Cement." Storage temperatures were $73 \mathrm{~F}$, the standard, and $122 \mathrm{~F}$. Determinations of heat of hydration made at 3,7 , and 28 days are tabulated below. The effects of the higher storage temperature at early ages are evident.

Heat of Hydration Test Results

\begin{tabular}{ccccc}
\hline $\begin{array}{c}\text { Storage } \\
\text { Temperature }\end{array}$ & & \multicolumn{2}{c}{$\begin{array}{c}\text { Heat of Hydration } \\
\text { Calories }\end{array}$} \\
\cline { 4 - 5 } F & & 3-Day & 7-Day & 28-Day \\
\hline 73 & & 55 & 69 & 77 \\
122 & & 67 & 74 & 78 \\
\hline
\end{tabular}

\section{Pozzolan (fly ash)}

12. The pozzolan, $\mathrm{AD}-566$, chosen was a fly ash from Waldorf, Maryland. Fly ash was ordered before the final scope of the study was established. A second shipment, AD-566(2), was needed. Samples of fly ash from both shipments were analyzed and found to meet ASTM C 618-77 for Class F pozzolan. Results of the analysis are shown in Table 4. Fly ash from the two shipments were batched 50 percent each by volume in all concrete mixtures in which fly ash was used. The specific gravities of the fly ash shipments were slightly different.

\section{Coarse aggregate}

13. Coarse aggregate was located and purchased by personnel of Baltimore District. The source at Williamsport, Maryland, was the same 
as for a shipment of 1-1/2-in. nominal maximum size limestone sent to WES for the ANMCC thermal study. The specifications given to Baltimore District by Omaha District were to locate and purchase 1-1/2-in. nominal maximum size dolomitic limestone. The material received at WES was $1-i n$. nominal maximum size limestone, CL-21 G-1(2). An inquiry was made, and it was learned that the wrong higher gradation was ordered. Limestone was substituted because the quarry manager did not feel that the newlyopened dolomitic limestone pit was producing research-grade aggregate at that time. The limestone source was well developed. After some discussion it was agreed that the study would proceed with the aggregate sent, but that comparison would be made to evaluate the effect of aggregate size on compressive and flexural strength. The remaining 1-1/2-in. aggregate, CL-21 G-1(1), from the earlier study was used in mixture $23 \mathrm{~A}$. Direct comparison with mixture 18 can be seen in Figure 2. Figure 2 shows that the 1-1/2-in. aggregate produced higher strengths than 1-in. aggregate. This is contrary to an accepted relationship of strength as a function of aggregate size for high-strength concrete. Aggregate quality may be responsible for the results seen here. A second shipment of the 1-in. aggregate, CL-21 G-1(3), was required because the amount of concrete required increased substantially after the original order was placed. Table 5 contains sieve analyses of all coarse aggregate used in the study.

\section{Fine aggregate}

14. The project fine aggregate, CL-21 S-1, was a natural quartz sand from Fayetteville, Pennsylvania. This sand was used in mixtures 1-8 before it was discovered that due to the low fineness modulus (2.27), it did not perform well with high-range, water-reducing admixture (HRWRA). Concrete made with this sand and HRWRA was either too harsh or exhibited extreme bleeding. At the time, the source of the problem was unknown, since no problems had previously been encountered at WES with the HRWRA. Several trial batches were evaluated to isolate the problem by varying the amount of HRWRA, sand-aggregate ratio, then finally swapping out cement, coarse aggregate, and sand one at a time with equivalent laboratory stock. The sand was identified as the problem. The project sand was 
replaced with an equivalent laboratory stock sand, CL-20 S-1, with a fineness modulus of 3.03 . No further problems were encountered. Sieve analysis of the project and laboratory stock sands are located in Table 6 . One mixture (No. 7) in which the project sand was used was repeated with the laboratory sand (No. 7A) for comparison of effects on compressive strength. Comparative strength gains for the two mixtures are shown in Figure 3 .

\section{Water-reducing admixtures}

15. Two types of water-reducing admixtures (WRA) were used in the investigation in addition to a group of mixtures with no WRA. The first is a conventional water reducer (CWRA). The second is a highrange water reducer (HRWRA). When compared with mixtures containing no WRA, the CWRA incorporated at $5 \mathrm{fl}$ oz per cwt of cement typically reduced water requirements by 10 percent. The HRWRA incorporated at 2 to 3.5 percent by weight of cement typically reduced water requirements by 20 to 25 percent. As discussed earlier, the HRWRA did not perform well with fine sand. In addition, workability declined rather rapidly in all mixtures after being discharged from the mixer. This loss of workability could be handled in the laboratory, but evaluation under field condition is recommended before using HRWRA. At the highest cement content of $940 \mathrm{lb} / \mathrm{ft}^{3}$, the concrete flowed (was self-leveling); however, once motion stopped, the concrete had the handling characteristics of previously vibrated concrete. If disposition of the concrete is directly from mixture to forms, the concrete would be acceptable. Long hauls in static transport would probably make subsequent handling very difficult. Steel fibers

16. Hooked steel fibers were used in all fiber mixtures. The primary fiber, ZP 50/0.50, was $50 \mathrm{~mm}$ long and $0.5 \mathrm{~mm}$ in diameter. These fibers are bonded together with water-soluble glue which dissolves during mixing, which provides good fiber dispersion. Minimal "balling" of fibers was observed. This fiber size was recommended by the manufacturer for high-strength concrete. Fibers with smaller diameters were reported to fail in tension and not at the concrete-steel bond. One supplemental mixture (No. 24S) was prepared with ZP 30/0.50 fibers, 
which were $30 \mathrm{~mm}$ long having the same diameter. Fibers were proportioned as coarse aggregate and were added at a rate of 1 percent by volume of mortar or 80 to $851 \mathrm{~b}$ per $\mathrm{yd}^{3}$ of concrete. This is approximately the amount recommended by the fiber manufacturer.

\section{Mixture Design Considerations}

17. The primary objective of Phase I was to achieve highest strength at an adequate level of workability for the range of cement contents considered. An alternate approach may have been to establish fixed levels of water-cement ratios and adjust cement contents and WRA for desired workability. In either case, the comparisons can be made that describe achievable strengths through a range of water-cement ratios and cement contents.

18. At each cement content and type of water-reducing admixture minimum water-cementitious materials ratios by weight were sought for all levels of pozzolan replacement for a slump of 2.5 to $3.0 \mathrm{in}$. In most cases desired workability was achieved without changing the amount of water for a given cement content and water-reducing admixture at all levels of pozzolan replacement. The result was that due to the lower specific gravity of pozzolan water-cementitious materials ratios by weight decreased as pozzolan replacement by volume increased.

19. In designing the fiber mixtures it was agreed from the outset that the fiber mixtures should not be designed in a way that might automatically force the compressive strengths of fiber mixtures to be higher than companion nonfiber mixtures. This approach was taken to fairly evaluate the effect of the fibers and not to "build in" a compressive strength increase which may be erroneously attributed to the fibers. Therefore, in all fiber mixtures the cement content was the same as the companion mixtures and variations made to the sand-aggregate ratio and water content to result in mixtures with a qualitatively equal workability when compared to the companion mixtures. As a result, an increase in water-cementitious material ratio in the fiber mixtures of generally 0.03 occurred. Compressive strengths were generally 400 to $500 \mathrm{psi}$ 
lower than the companion nonfiber mixtures. The one case where the difference in W/C was 0.01 the fiber mixtures were 120 to 190 psi higher. Adjusting for the effects of the differences in $\mathrm{W} / \mathrm{C}$, the compressive strengths of fiber versus nonfiber mixtures were well within the coefficients of variation of each.

20. At highest cement contents it was necessary to vary sandaggregate ratios especially as water-reducing admixtures changed to achieve workabilities desired. This somewhat reduced equatability between mixtures. The workability of mixtures with the equivalent of $940 \mathrm{1b} / \mathrm{yd}^{3}$ cement was not the same as for lower cement contents, probably for the simple reason that they were inherently stickier because of the high cement content.

21. In addition, it was found that the amount of vibration strongly affects compressive strengths at high cement contents. The first batch of mixture 21 was vibrated vigorously, but this caused the disposable plastic molds to split. Subsequent batches were vibrated slightly less. The compressive strength of the first batch was approximately 10 percent higher than the second and third batches. Compressive strengths for this mixture at 1 year show that the lesser vibration of batches 2 and 3 caused strengths to be 600 to 700 psi less than those of the first batch. 


\section{PART III: CONCRETE TESTING}

\section{Specimen Curing Conditions}

22. Curing conditions for the concrete were formulated to provide compressive strength data for in situ conditions. Results from the ANMCC thermal study indicated initial peak temperatures exceeding $130 \mathrm{~F}$ and average temperatures greater than $120 \mathrm{~F}$ would exist in the cavity linings for up to 90 days if cast-in-place cellular concrete was used as a backpacking material. Therefore, one elevated and one standard temperature cure were employed in the study. The elevated temperature cure consisted of specimen storage at $90 \mathrm{~F}$ for the first day after casting to simulate initial temperature rise, followed by storage at $122 \mathrm{~F}$ until 90-days age to simulate the longest cooling period; $73 \mathrm{~F}$ curing temperature was maintained after 90 days. Constant storage temperature of $73 \mathrm{~F}$ was maintained for the duration of the curing period in the standard temperature cure.

23. Two moisture conditions were maintained during concrete curing. A set of specimens from each primary and all but one supplemental mixture in Phase I were stored in a sealed condition at each curing temperature. This condition simulates the probable curing condition for the ANIP cavity linings. These specimens were tested at ages of 3,28 , and 90 days, and 1 year. The test at 3-days age was selected instead of at 7-days age to better document the differences in early-age strengths between the standard and elevated temperature cures.

24. In addition six mixtures were selected from the original matrix of mixtures, from which a set of specimens was also immersion cured at both temperatures. This curing condition was used to observe the effects of optimum curing condition. All specimens from these mixtures were tested at two additional ages, namely, 7 days and 2 years. It was felt that the procedure for testing described above would produce acceptable data while reducing batching and testing costs and still provide a basis for extrapolating or interpolating strength at ages for which tests were not conducted. 
25. All specimens were prepared in three batches with one specimen from each batch provided for each combination of curing environments. Therefore, 6 specimens were prepared and tested at each age in the sealed cure while 12 specimens were tested at each age for the combined sealed and immersed cures. Using three batches increased concrete preparation and testing costs. Even though quality control in the laboratory was generally very good, it was found that occasionally somewhat large across-batch variations did occur. The use of three batches improved the confidence in and statistical accuracy of the results of the study.

\section{Specimen Preparation}

26. Al1 compressive strength test specimens, 6- by 12-in. cylinders, were cast in disposable plastic molds, and vibrated internally. Al1 specimens were sealed after casting using snap-on plastic caps. A silicon caulk was used to seal the cap to the cylinder mold and as a precaution against moisture loss, plasticized duct tape was tightly wrapped around the mold-cap interface. Immersed specimens were stripped from the molds at an age of 1 day and placed in $73 \mathrm{~F}$ or $122 \mathrm{~F}$ lime water, depending upon the curing temperature desired. All other cylinders remained sealed at the appropriate curing temperature until prepared for testing. All cylinders were weighed to the nearest $0.01 \mathrm{lb}$ at casting and were weighed again after being stripped for testing. Immersed specimens were weighed after removal from the water. No moisture losses were observed in the sealed specimens. Immersed specimens showed a very slight moisture gain. The ends of all cylinders estimated to fail below 9000 psi were capped. Those estimated to fail above 9000 psi were surface ground.

27. Flexural strength test specimens for Phase I were cast 6 - by 6- by 36-in. beams. Al1 fiber and companion nonfiber mixtures in the flexural strength evaluation contained 35 percent fly ash replacement. This was done because during planning it was presumed that a mixture with pozzolan replacement would be needed to would meet both the longterm high strength and early-age low heat production requirements. 
Original plans called for two beams to be cast from each mixture for test at 90-days age. However, mixtures batched near the end of the casting period were cast with four beams for testing at 28- and 90-days age. Specimens were stored in the fog room at $73 \mathrm{~F}$ until tested in third point loading. If sufficient beam length remained after the test, a second break was obtained from each beam. A minimum of three breaks was obtained at each test age.

28. Tensile strain capacity test specimens for Phase II were cast 6- by 6- by 30-in. beams. After casting, the specimens were taped sealed with polyethylene film and placed in $73 \mathrm{~F}$ and $90 \mathrm{~F}$ curing environments specified for the first day. At 1-day age the beams were stripped and sealed in a membrane to prevent drying. Specimens were then cured at the temperature environments described in paragraph 22.

\section{Tests and Procedures}

29. This section describes the actual tests and procedures used during this investigation to quantify or define the mechanical and thermal properties desired for the concrete mixtures in Phases I and II. All of the mechanical properties tests in Phase II were conducted at ages of $1,3,7,28,90$, and 365 days. Thermal properties tests were conducted at 28 days.

Compressive strength, modulus of elasticity, and Poisson's ratio

30. Compressive strength tests of concrete specimens were conducted in accordance with the provisions of CRD-C $14-73,5$ "Standard Method of Test for Compressive Strength of Cylindrical Concrete Specimens." Modulus of elasticity and Poisson's ratio were determined for concrete specimens in accordance with CRD-C 19-75, 5 "Standard Method of Test for Static Modulus of Elasticity and Poisson's Ratio of Concrete in Compression." 
Flexural strength (modulus of

rupture) and tensile strain capacity

31. Flexural strength tests in Phase $I$ were conducted in accordance with CRD-C 16-76, "Standard Method of Test for Flexural Strength of Concrete." Tensile strain capacity tests in Phase II were conducted in accordance with CRD-C $71-80,{ }^{5}$ "Standard Test Method for Ultimate Tensile Strain Capacity of Concrete," with the following exceptions. Instead of the standard 12- by 12- by 30-in. beams, 6- by 6- by 30-in. beams were used because of the 1-in. aggregate size used in the concrete mixtures. The test method was designed for larger-aggregate mass concrete mixtures. Also, the slow loading tests were omitted. Externally mounted strain gages were used to monitor strains. Modulus of rupture in the third-point loading of the tensile strain capacity test is calculated according to the procedure given in CRD-C 16-76.

Thermal diffusivity, specific

heat, and thermal conductivity

32. Thermal properties were determined in Phase II. Thermal diffusivity, the index of the facility with which a material will undergo temperature change, was conducted on specimens of concrete mixture 13 in accordance with CRD-C 36-73, 5 "Method of Test for Thermal Diffusivity of Concrete." Specific heat, the amount of heat required to raise a unit mass of material by unit temperature change, was conducted on specimens of mixture 13 in accordance with CRD-C 124-73, 5 "Method of Test for Specific Heat of Aggregates, Concrete, and Other Materials (Method of Mixtures)." The apparent densities of mixture 13 were conducted in accordance with CRD-C 107-69, 5 "Standard Method of Test for Specific Gravity, Absorption, and Unit Weight of Coarse Aggregates and Riprap." Thermal conductivity, the measure of the ease with which heat is able to flow through a material, was calculated for mixture 13 in accordance with the provisions of CRD-C 44-63, "Method for Calculation of Thermal Conductivity of Concrete." In the method thermal conductivity is computed as the product of thermal diffusivity, specific heat, and density. 


\section{Adiabatic temperature rise}

33. Adiabatic temperature rise was determined for concrete mixture No. 13 in accordance with CRD-C 38-73, 5 "Method of Test for Temperature Rise in Concrete." This method covers the procedure for determining the temperature rise in concrete under adiabatic conditions primarily due to the heat liberated on hydration of cement.

\section{Coefficient of thermal expansion}

34. Tests to determine the coefficient of thermal expansion were conducted on specimens of mixture 13 in Phase II in accordance with CRD-C 39-55, "Method of Test for Coefficient of Linear Thermal Expansion of Concrete." 


\section{PART IV: TEST RESULTS}

\section{Phase I Tests}

\section{Compressive strength}

35. Compressive strength results are tabulated in Tables 7-12 in several different ways to assist in evaluating the effects of the variables. Specifically, Table 7 shows strength in order of increasing cement content for all mixtures; Table 8 shows strengths in order of decreasing water-cementitious materials ratio for all mixtures; and Tables 9-12 show strengths in order of decreasing water-cementitious materials ratio for $0,20,35$, and 50 percent fly ash replacements, respectively. Table 13 contains compressive and flexural (modulus of rupture) strength for fiber and nonfiber companion mixtures. Only mixtures 13, 17, 17A, and 20 without fly ash replacement and with HRWRA exceed compressive strengths of 9000 psi at 1 year for all curing conditions. Compressive strengths of mixtures 9, 14, 15, 23,23A, 24, 24S, 10, and 21 with fly ash replacement exceeded 9000 psi at 1 year only at the $73 \mathrm{~F}$ cure with the exception of mixture 21 when immersed at the $122 \mathrm{~F}$ cure. Al1 of these mixtures contained HRWRA except mixture 10 with CWRA. No mixture with fly ash cured sealed at $122 \mathrm{~F}$ exceeded $9000 \mathrm{psi}$. And all mixtures contained solid volume equivalents of at least $7991 \mathrm{~b}$ of cement except mixture 13 at $658 \mathrm{lb}$. Of those tested at 2 years only specimens at certain curing conditions for mixtures 13,17, 18, 20, and 21 exceeded 11,000 psi. Mixtures 18 and 21 with fly ash only exceeded 11,000 psi for the immersed, $73 \mathrm{~F}$ curing condition. Note that additional data are shown for 2-years age than the six mixtures scheduled for testing at 2 years. These data are the result of tests conducted on extra 6- by 12-in. cylinders and were included to supplement the results of planned tests.

36. One of the most important results of the study involves the effects on specimens cured at $122 \mathrm{~F}$. The general effect of the $122 \mathrm{~F}$ cure was to accelerate early-age compressive strengths and produce lower extended-age strengths. Not surprisingly, virtually all strengths of specimens cured at $122 \mathrm{~F}$ are lower than those cured at $73 \mathrm{~F}$, but the 
difference is much greater when fly ash replacement is used. At the $122 \mathrm{~F}$ cure, early-age strengths are higher than at the $73 \mathrm{~F}$ cure. However, the strength gain after 28 days is almost nonexistent in fly ash mixtures so that compressive strengths at 1 year from the $73 \mathrm{~F}$ cure are much higher. The last column in Tables 9-12 shows the percentage strength gain at 1 year with respect to strengths at 28 days. The detrimental effects of higher curing temperature when fly ash is used is evident. In addition, extrapolation of the strength gain curves indicates that the effect of the curing temperature will continue to grow after 1 year. The typical combined effect of $\mathrm{fly}$ ash replacement and curing temperature is seen in Figures 4 and 5. Figures $4 a$ and $5 a$ show compressive strength gain in mixtures containing HRWRA as a function of cement content without fly ash and with 35 percent fly ash replacement, respectively, at $73 \mathrm{~F}$ curing temperature. Figures $4 \mathrm{~b}$ and $5 \mathrm{~b}$ show the same relationship at curing temperature of $122 \mathrm{~F}$. The lower strength gain for fly ash and replacement mixtures at $122 \mathrm{~F}$ in Figure $5 \mathrm{~b}$ is evident.

37. Figures 6-8 show compressive strength gain versus fly ash replacement percentages at three increasing levels of water reduction, respectively. In Figures $6 a, 7 a$, and $8 a$ compressive strength gains for mixtures 1-4, 5-8, and 13-18 with no water reducer, CWRA, and HRWRA, respectively, are shown at a curing temperature of $73 \mathrm{~F}$. Figures $6 \mathrm{~b}, 7 \mathrm{~b}$, and $8 \mathrm{~b}$ show the same relationships at a curing temperature of $122 \mathrm{~F}$. All of these mixtures contained a constant cementitious materials solid volume of $3.347 \mathrm{cu} \mathrm{ft/cu} \mathrm{yd} \mathrm{of} \mathrm{concrete.} \mathrm{These} \mathrm{figures} \mathrm{again} \mathrm{demonstrate}$ the lack of strength gain after 28-days age for mixtures containing fly ash and cured at $122 \mathrm{~F}$. Compressive strength gains of mixtures with no fly ash at $122 \mathrm{~F}$ are less than at $73 \mathrm{~F}$, but some increase in strength continues.

38. Figures $6 a, 7 a$, and $8 a$ show that at curing temperatures of $73 \mathrm{~F}$ compressive strengths at 1- and 2-years age are nearly equal for fly ash replacements from 0 to 35 percent when no WRA and CWRA were used. When HRWRA is used, strength gains are nearly equal only up to 20 percent fly ash replacement. Compressive strengths at 35 percent fly ash 
replacement are nearly equal for CWRA and HRWRA usage even though W/C ratios are 0.476 and 0.404 , respectively.

39. Figure 9 shows compressive strength gain when no water reducer, CWRA, and HRWRA are used at 35 percent fly ash replacement for mixtures 3,7 , and 15, respectively. The lack of strength gain at curing temperature of $122 \mathrm{~F}$ for $\mathrm{fly}$ ash replacement is again demonstrated vividly.

40. Figures 10-15 show compressive strength gains for the six mixtures cured at two temperatures and two moisture conditions. Figures 10-11 show strength gains for mixtures 13 and 20 with no fly ash replacement, respectively. Figures 12-15 show strength gains for mixtures $7,15,18$, and 21 , respectively, with 35 percent fly ash replacement.

41. Mixtures without fly ash replacement appear to be only slightly affected by higher curing temperature and immersion curing. Compressive strengths are slightly higher at early ages and approximately equal at extended ages. Immersion curing appears to increase strengths slightly as time passes although the increase in strength probably ends by 90 -days age.

42. Mixtures with fly ash replacement appear to be substantially more sensitive to temperature and moisture curing conditions. Fly ash mixtures at all cement contents and with CWRA and HRWRA produced compressive strengths at 3- and 7-days age that were 1000 psi or greater when cured at $122 \mathrm{~F}$. At ages between 28 and 90 days, the specimens cured at both temperatures had nearly equal strength with little or no subsequent gain for specimens cured at $122 \mathrm{~F}$. Except for mixture 7 with CWRA, specimens from all other fly ash mixtures with HRWRA cured in sealed and immersed conditions exhibited nearly equal increases in strength versus age when immersed, regardless of curing temperature. Thus, the lack of strength gain after 28-days age for most fly ash mixtures cured sealed at $122 \mathrm{~F}$ cannot be attributed to moisture loss since immersion increases strength nearly equally for $73 \mathrm{~F}$ and $122 \mathrm{~F}$ cured specimens.

43. Chemical analyses of cement and fly ash used in this investigation do not indicate an adverse reaction due to temperature. In order 
to eliminate the specific cementitious materials used in this investigation as the cause of lower strengths at the $122 \mathrm{~F}$ curing temperature, mixture 15 was rebatched, replacing first the project cement (No. 15RC) then the $f 1 y$ ash (No. $15 \mathrm{RF}$ ) with materials in stock at WES. ${ }^{6}$ The results of this comparison are shown in Table 14 and plotted in Figure 16. These data show that the same effects are seen from use of the alternate cement and $f l y$ ash. It is believed that the simulated adiabatic temperature curing condition which approximates the conditions in ANIP 1iners during the first day is the primary cause of reduced strength gain in the f1y ash concrete mixture at ages greater than 28 days for the $122 \mathrm{~F}$ curing condition. This conclusion is supported by the results of another investigation ${ }^{7}$ at WES. Cement paste specimens with 30 percent fly ash by volume were cured at $95 \mathrm{~F}$ for the first 24 hours and at $75 \mathrm{~F}$ thereafter produced strengths up to 20 percent lower than specimens cured at $73 \mathrm{~F}$ for the entire year.

44. The results discussed above, if found to hold for all fly ashes when cured at elevated temperatures, deserve some attention in regard to normal mixture design practices. The curing temperature of virtually all concrete mixtures design studies is $73 \mathrm{~F}$. If any concrete mixture is to exist in an elevated temperature environment for a period of time after placement and contain fly ash replacement, compressive strength determined at normal curing temperature will be greater than can be expected from the in situ temperature cure possibly even before 28-days age. And the difference will become greater with age. Therefore, some of the conservatism of design built into concrete structures may be canceled because the concrete could have lower strength than design specifications called for. The problem is that this may be unknown to design engineers. In most cases, judging by the results of this investigation, a concrete mixture without $\mathrm{fly}$ ash and with lower cement content would provide the desired compressive strength at the in situ temperature. And the cost of cementitious materials and heat produced could be less than for the fly ash mixture that is of reduced strength due to temperature curing conditions. 
Flexural strength

45. Flexural strength (modulus of rupture) results were compared. When adjusted for water-cementitious materials ratio, compressive strengths are nearly equal for fiber and comparative nonfiber mixtures. All flexural strength tests were conducted on specimens from mixtures containing 35 percent fly ash. Flexural strengths at 90-days age were nearly the same for fiber and nonfiber mixtures alike at 1000 to 1100 psi. This relationship held for cementitious material equivalents of 517 through 779 lb/yd, for mixtures with long ( $50 \mathrm{~mm})$ and short (30 mm) fibers, and for mixtures with 1.0-in. and 1.5-in. maximum size aggregate. Flexural strengths at 28-days age ranged from 670 psi to 1000 psi. Minimum values were seen for mixture 26 at the lowest cementitious materials content. Maximum values were observed for mixture 24 with 1-in. maximum size aggregate, 50-mm fibers, and maximum cementitious material content (solid volume $=4.065 \mathrm{cu} \mathrm{ft} / \mathrm{cu} \mathrm{yd}$ ) used in the flexural strength series.

46. One advantage seen in the use of fibers was that compressive strength and flexural strength specimens yielded slowly at failure rather than abruptly or explosively failing. This may be of benefit to ANIP because prefailure ductility may be increased. An inquiry made with personnel of Walla Walla District yielded a general observation regarding the effect of fibers on tensile strain capacity. They have found that tensile strain capacity increases by a factor of two or three when fibers are used. Therefore, it may be appropriate to include compressive and flexural response of the liner beyond the elastic range in the design when steel fibers are used.

\section{Phase II Tests}

47. Based upon the strength criteria specified for this investigation, mixture 13 was selected for additional testing in Phase II because no mixtures with fly ash replacement met strength specifications at both curing temperatures. This selection was made after 1-year test data were available, but before 2-year tests were made. At 1 year, average 
compressive strengths were $10,480 \mathrm{psi}$ at the $73 \mathrm{~F}$ cure and 10,100 at the $122 \mathrm{~F}$ cure for sealed specimens. It was expected that strength increases to 2-years age would provide compressive strengths in excess of 11,000 psi as required. Actual strengths at 2 -years age were 10,310 psi at $73 \mathrm{~F}$ and $11,340 \mathrm{psi}$ at $122 \mathrm{~F}$.

48. Phase II was conducted to provide thermal and mechanical properties of a concrete mixture meeting strength specifications for ANIP. These data were for use in completing thermal stress computer simulations in the ANMCC thermal study.

49. Table 15 contains basic concrete properties of compressive strength, Poisson's ratio, modulus of elasticity, and modulus of rupture as a function of age at specimen storage temperatures of $73 \mathrm{~F}$ and $122 \mathrm{~F}$. Compressive strengths compared favorably with values for mixture 13 in Phase I. Moduli of rupture at the $73 \mathrm{~F}$ curing temperature are slightly less (920 psi) than the values for all mixtures tested in Phase I ( 1000 to $1100 \mathrm{psi})$. The difference may be that Phase I specimens were cured in 100 percent humidity, whereas Phase II specimens were sealed. Specimens cured at $122 \mathrm{~F}$ were slightly higher at all ages.

50. Moduli of elasticity are slightly higher at ealier ages at the $122 \mathrm{~F}$ cure, but are equal at 1 year. The values of 3.86 and 4.11 x $10^{6}$ psi at 1 day for $73 \mathrm{~F}$ and $122 \mathrm{~F}$ curing conditions, respectively, are approximately 60 percent of 1-year values. Poisson's ratios are approximately the same regardless of curing condition, however, values increase from approximately 0.17 at 1 day to approximately 0.21 at 1 year.

51. Strain capacity data from third-point loading beam tests are tabulated in Table 16. Tensile strain capacity values are used in thermal strain analyses as the tensile strain limit. Values of 104 and 114 x $10^{-6}$ in./in. from $73 \mathrm{~F}$ and $122 \mathrm{~F}$ curing environments, respectively, at 1 day are approximately 75 percent of 1-year values, and tensile strain capacity specimens cured at $122 \mathrm{~F}$ are slightly higher than those cured at $73 \mathrm{~F}$ at most ages.

52. Thermal properties tests were conducted only on specimens cured at $73 \mathrm{~F}$. Results of these tests are as follows:

Thermal diffusivity - $0.0367 \mathrm{ft}^{2} / \mathrm{hr}$ 
Specific heat $-0.218 \mathrm{Btu} / \mathrm{lb}-\mathrm{F}$

Density - $154.81 \mathrm{~b} / \mathrm{ft}^{3}$

Thermal conductivity $-1.239 \mathrm{Btu}-\mathrm{ft} / \mathrm{hr}-\mathrm{ft}^{2}-\mathrm{F}$

Linear thermal expansion $-5.27 \times 10^{-6}$ in./in. $-F$

53. Adiabatic temperature rise is tabulated in Table 17 and plotted in Figure 18. An adiabatic temperature rise of $81.8 \mathrm{~F}$ occurred up to 28-days age with approximately $1 \mathrm{~F}$ rise after 7-days age. Since placement temperature was $58.4 \mathrm{~F}$, the actual temperature at 28-days age was $140.2 \mathrm{~F}$. The $81.8 \mathrm{~F}$ rise at 28-days age is approximately $12.4 \mathrm{~F}$ per cwt of cement or a typical value for mass concrete. At 1-day the temperature rise of $7.1 \mathrm{~F}$ per cwt is somewhat higher than for typical mass concrete. This is presumed to be due to accelerated hydration while the specimen temperature was reaching $105 \mathrm{~F}$ by 1 day. 


\section{PART V: REVIEW AND RECOMMENDATIONS}

\section{Phase I}

54. The results of this investigation indicate that when using a Type $\mathrm{V}$ or Type II cement with heat of hydration limit that a lowest cement content of $658 \mathrm{lb}$ and use of HRWRA will produce compressive strengths exceeding 9,000 psi at 1 year and 11,000 psi at 2 years regardless of curing condition. Strengths achieved with mixture 18 containing the 1-in. nominal maximum size aggregate were lower than those of companion mixture $23 \mathrm{~A}$ with $1-1 / 2-i n$. nominal maximum size aggregate. Some researchers have found higher strengths are associated with smaller nominal maximum aggregate sizes. The results noted above may indicate that the 1 -in. nominal maximum size limestone aggregate was inferior to the nominal 1-1/2-in. maximum size limestone aggregate used in mixture $23 \mathrm{~A}$ and originally used in the ANMCC thermal study. Both aggregates were from the same source. Because concrete with 1-in. aggregate might have been expected to be stronger than with 1-1/2-in. aggregate and considering the results of the comparison between mixtures 18 and $23 \mathrm{~A}$, it is logical to assume that mixture 18 proportioned with aggregate of equal or better quality than the 1-1/2-in. aggregate used in mixture $23 \mathrm{~A}$ should produce strengths at least 10 percent higher than achieved in this study. Therefore, two recommendations are in order. First, because aggregate quality may limit ultimate strength, consideration should be given to procuring aggregate outside of the immediate vicinity of the project if necessary. Secondly, consideration should be given to changing the maximum aggregate size to conform to the range of maximum aggregate size capable of producing highest strengths. Compressive strengths of 11,000 psi at 2-years age should then be easily achieved.

55. The investigation also showed that for the in situ temperature cure chosen ( $90 \mathrm{~F}$ for day 1, $122 \mathrm{~F}$ for 89 days, then $73 \mathrm{~F}$ ) al1 mixtures containing fly ash after exhibiting initial accelerated strength yielded minimal strength gain after approximately 28-days age. It is believed that the curing condition used during the first day is the 
primary cause. However, the specimen temperatures during the first day are characteristic of those predicted for ANIP. All mixture proportioning investigations should examine the in situ temperature effects if fly ash replacement is contemplated.

56. In using the $73 \mathrm{~F}$ curing temperature as the basis for comparison, optimum percentages of $\mathrm{fly}$ ash replacement were 35 percent when CWRA was used and 20 percent when HRWRA was used. The effect of immersion curing was a slight, gradual increase in compressive strength above that of sealed curing. The slight increase was also seen when fly ash mixtures were cured immersed compared with sealed at $122 \mathrm{~F}$. The increase in strength due to immersion was nearly the same at $73 \mathrm{~F}$ and $122 \mathrm{~F}$. Strength increase due to immersion at 1 year was generally less than 7 percent for non-fly ash mixtures and between 13 and 21 percent for mixtures containing fly ash.

57. Based upon mixtures containing 658 lb of cement, use of CWRA reduced water-cement ratio by weight by 11 percent. Use of HRWRA reduced water-cement ratios by 24 percent. Compressive strengths at 1 year for $73 \mathrm{~F}$ curing temperatures in a sealed condition were $7,420,8,370$, and 10,480 psi when using no WRA, CWRA, and HRWRA, respectively. The increase in strength with CWRA is 12.8 percent and with HRWRA is 41.2 percent when compared with no WRA usage.

58. Results of this investigation indicated that for a compressive strength of at least 5500 psi at 90-days age, flexural strengths are nearly equal regardless of cement content for both fiber and companion nonfiber mixtures at approximately 1000 to 1100 psi. All mixtures tested contained 35 percent fly ash replacement cured in 100 percent humidity at $73 \mathrm{~F}$. With all factors being equal the use of fibers does not improve flexural strength, but does control the rate of failure. It was also learned that investigators at Walla Walla District have found that generally tensile strain capacity increases by a factor of two or three when fibers are used. Ductility may therefore be increased which may make fiber concrete desirable in ANIP. 
59. In this phase additional tests were conducted on specimens from mixture 13 cured sealed at $73 \mathrm{~F}$ and $122 \mathrm{~F}$. Test results showed that moduli of elasticity at 1 day are 3.85 and 4.11 for the $73 \mathrm{~F}$ and $122 \mathrm{~F}$ cure, respectively. The moduli remain slightly higher for specimens cured at $122 \mathrm{~F}$ but are nearly equal to those cured at $73 \mathrm{~F}$ at 1 year. The same relationship exists for compressive strength. Tensile strain capacity and flexural strength test results on specimens cured at $122 \mathrm{~F}$ remained higher than those cured at $73 \mathrm{~F}$ even at a year. Flexural strength at 90-days age on sealed specimens at $73 \mathrm{~F}$ was approximately 1000 psi lower than Phase II specimens cured at $122 \mathrm{~F}$ and all mixtures cured at 100 percent humidity in Phase I.

60. Thermal properties of mixture 13 were determined from specimens cured only at $73 \mathrm{~F}$. Values of $0.0367 \mathrm{ft}^{2} /$ hour, $0.218 \mathrm{Btu} / 1 \mathrm{~b}-\mathrm{F}$, and $1.239 \mathrm{Btu} / \mathrm{hr}-\mathrm{ft}-\mathrm{F}$ for thermal diffusivity, specific heat, and thermal conductivity, respectively, were typical for concrete. Adiabatic temperature rise at 28 -days age was $81.8 \mathrm{~F}$. The temperature rise at 1 day was $46.7 \mathrm{~F}$ when added to the placement temperature of $58.4 \mathrm{~F}$ yield $105 \mathrm{~F}$. Accelerated hydration is presumed to have occurred during the first several days to produce heat of hydration similar to that determined at the $122 \mathrm{~F}$ storage temperature and reported in paragraph 11.

\section{High-Strength Concrete Placement Guidelines}

61. The following guidelines are submitted for successful placement of high-strength concrete similar to that of mixture 13 containing 3-in. slumop, HRWRA, and 600 to $800 \mathrm{lb}$ of cement per cubic yard in a warm environment assumed to exist in ANIP.

a. The compatibility of the cement to be used should be checked with the HRWRA. Various combinations of $\mathrm{C}_{3} \mathrm{~A}$ and fineness of cement with the HRWRA can cause severe slump loss problems. If it becomes necessary to change cements during the course of the job, the substitute cement should also be checked. Extreme variations in sand gradation such as extreme fineness should also be avoided. 
b. The recommended dosage of HRWRA should not be exceeded as loss of plasticity or a "gummy, sticky" mixture may result. Be aware that this condition can occur as the maximum dosage is approached when other factors such as a change in the mixture fines or higher temperatures occur. Retempering, the process of adding additional admixture to restore lost slump, is feasible but should not be used indiscriminately.

c. A special effort should be made to mix the concrete as close to the placing site as possible with minimal time loss between mixing and placing. When placement is to be done underground, mixing should also be underground. If there is a time differential of 20 to 30 minutes between the primary batching, mixing, and placing operations, consideration should be given to adding and mixing the HRWRA immediately prior to placing. Modern, wellmaintained concrete pumps may be used effectively to transport the concrete to the placement area. Any methods of transport which vibrate or cause the concrete to settle such as buckets on rail cars should be avoided. Transport by belt conveyor in hot, windy conditions should also be avoided.

d. Cold water or chipped ice should be used in place of mixing water to lower mixture temperature to help extend workability as needed. Lowered mixture temperatures will also reduce peak temperature minimizing thermal expansions and cracking problems. Conventional retarding admixtures may also be used to extend workability time in superplasticized mixtures. Trial mixtures should be made, however, when additional admixtures are to be used.

e. Place, vibrate, and cure concrete with HRWRA using the same procedures as conventional concrete. Special effort should be made, however, to accomplish these tasks as quickly as possible, especially in warm environments. 


\section{REFERENCES}

1. Bombich, A. A., "Thermal Studies in Support of the ANMCC Improvement Project," in preparation, U. S. Army Engineer Waterways Experiment Station, CE, Vicksburg, MS.

2. Mather, Bryant, "Investigation of Cement-Replacement Materials, Report 12, Compressive Strength Development of 193 Concrete Mixtures During 10 Years of Moist Curing (Phase A)," Miscellaneous Paper No. 6-123, Apr 1965, U. S. Army Engineer Waterways Experiment Station, CE, Vicksburg, MS.

3. Klieger, Paul, "Effect of Mixing and Curing Temperature on Concrete Strength," Journal, American Concrete Institute, Jun 1958, p 10631081 .

4. 1977 ASTM Annual Book of Standards, Philadelphia, PA.

5. U. S. Army Engineer Waterways Experiment Station, CE, "Handbook for Concrete and Cement," Aug 1949, with quarterly supplements, Vicksburg, MS.

6. Holland, T. C., Liu, T. C., and Bombich, A. A., "Determination of Properties of Concrete Used in Thermal Studies for Lock and Dam No. 2, Red River Waterway," Miscellaneous Paper SL-82-5, Jun 1982, U. S. Army Engineer Waterways Experiment Station, CE, Vicksburg, MS.

7. Mather, K., Burkes, J. P., Wong, G. S., and Reinhold, R. E., "Effects of Accelerated Curing on Hydration Products of Cement and CementF1y Ash Pastes," Miscellaneous Paper C-78-11, Aug 1978, U. S. Army Engineer Waterways Experiment Station, CE, Vicksburg, MS.

8. Steel, R. G. D. and Torrie, J. H., Principles and Procedures of Statistics A Biometric Approach, 2nd ed, McGraw-Hill, New York, 1980. 
Table 1

High-Strength Concrete Optimization Study Mixtures

\begin{tabular}{|c|c|c|c|c|c|c|c|c|c|}
\hline \multirow{2}{*}{$\begin{array}{c}\text { Water- } \\
\text { Reducing } \\
\text { Admixtures } \\
\end{array}$} & \multirow[b]{2}{*}{$\begin{array}{l}\text { Mixture } \\
\text { No. }\end{array}$} & \multirow[b]{2}{*}{$\frac{\text { Cementitious }}{\left(\text { bags/yd } / \mathrm{d}^{3}\right)^{\star}}$} & \multirow[b]{2}{*}{$\begin{array}{l}\text { Content } \\
\mathrm{ft}^{3} / \mathrm{yd}^{3} \\
\end{array}$} & \multirow{2}{*}{$\begin{array}{c}\text { Pozzolan } \\
\text { Replacement } \\
\% \\
\end{array}$} & \multicolumn{4}{|c|}{ Curing Conditions } & \multirow[b]{2}{*}{$\begin{array}{c}\text { Test } \\
\text { Ages** }\end{array}$} \\
\hline & & & & & $\frac{\text { Sea }]}{22 \mathrm{C}}$ & $\frac{e d}{50 C}$ & $\frac{\underline{I m m e}}{\underline{22 \mathrm{C}}}$ & $\frac{\mathrm{esed}}{50 \mathrm{C}}$ & \\
\hline \multirow{4}{*}{ None } & 1 & 7.0 & 3.347 & 0 & $\mathrm{x}$ & $\mathrm{x}$ & & & I \\
\hline & 2 & 7.0 & 3.347 & 20 & $\mathrm{x}$ & $\mathrm{x}$ & & & I \\
\hline & 3 & 7.0 & 3.347 & 35 & $\mathrm{x}$ & $\mathrm{x}$ & & & I \\
\hline & 4 & 7.0 & 3.347 & 50 & $\mathrm{x}$ & $\mathrm{x}$ & & & I \\
\hline \multirow[t]{7}{*}{ Conventional } & 25 & 5.5 & 2.630 & 35 & $\mathrm{x}$ & $\mathrm{x}$ & & & I \\
\hline & 5 & 7.0 & 3.347 & 0 & $\mathrm{x}$ & $\mathrm{x}$ & & & I \\
\hline & 6 & 7.0 & 3.347 & 20 & $\mathrm{x}$ & $\mathrm{x}$ & & & I \\
\hline & 7 & 7.0 & 3.347 & 35 & $\mathrm{x}$ & $\mathrm{x}$ & $\mathrm{x}$ & $\mathrm{x}$ & II \\
\hline & 8 & 7.0 & 3.347 & 50 & $\mathrm{x}$ & $\mathrm{x}$ & & & I \\
\hline & 9 & 8.5 & 4.065 & 35 & $\mathrm{x}$ & $\mathrm{x}$ & & & I \\
\hline & 10 & 10.0 & 4.782 & 35 & $\mathrm{x}$ & $\mathrm{x}$ & & & I \\
\hline \multirow[t]{13}{*}{ High-Range } & 26 & 5.5 & 2.630 & 0 & $\mathrm{x}$ & $\mathrm{x}$ & & & I \\
\hline & 27 & 5.5 & 2.630 & 35 & $\mathrm{X}$ & $\mathrm{x}$ & & & I \\
\hline & 13 & 7.0 & 3.347 & 0 & $\mathrm{x}$ & $\mathrm{x}$ & $\mathrm{x}$ & $\mathrm{x}$ & II \\
\hline & 14 & 7.0 & 3.347 & 20 & $\mathrm{x}$ & $\mathrm{x}$ & & & I \\
\hline & 15 & 7.0 & 3.347 & 35 & $\mathrm{x}$ & $\mathrm{x}$ & $\mathrm{x}$ & $\mathrm{x}$ & II \\
\hline & 16 & 7.0 & 3.347 & 50 & $\mathrm{x}$ & $\mathrm{x}$ & & & I \\
\hline & 17 & 8.5 & 4.065 & 0 & $\mathrm{x}$ & $\mathrm{x}$ & & & I \\
\hline & 18 & 8.5 & 4.065 & 35 & $\mathrm{X}$ & $\mathrm{x}$ & $\mathrm{x}$ & $\mathrm{x}$ & II \\
\hline & $23 \mathrm{~A}^{\top}$ & 8.5 & 4.065 & 35 & $x$ & $\mathrm{x}$ & & & I \\
\hline & 19 & 8.5 & 4.065 & 50 & $\mathrm{x}$ & $\mathrm{x}$ & & & I \\
\hline & 20 & 10.0 & 4.782 & 0 & $\mathrm{x}$ & $\mathrm{X}$ & $\mathrm{x}$ & $\mathrm{X}$ & II \\
\hline & 21 & 10.0 & 4.782 & 35 & $\mathrm{x}$ & $\mathrm{x}$ & $\mathrm{X}$ & $\mathrm{X}$ & II \\
\hline & 22 & 10.0 & 4.782 & 50 & $\mathrm{x}$ & $\mathrm{x}$ & & & I \\
\hline \multicolumn{10}{|c|}{ Mixtures with Steel Fibers } \\
\hline \multirow[t]{2}{*}{ Conventional } & 11 & 7.0 & 3.347 & 35 & $\mathrm{x}$ & $\mathrm{x}$ & & & I (III) \\
\hline & 12 & 8.5 & 4.065 & 35 & $\mathrm{x}$ & $\mathrm{x}$ & & & I (III) \\
\hline \multirow[t]{2}{*}{ High-Range } & $23^{\top}$ & 8.5 & 4.065 & 35 & $\mathrm{x}$ & $\mathrm{x}$ & & & I (III) \\
\hline & 24 & 8.5 & 4.065 & 35 & $\mathrm{X}$ & $\mathrm{X}$ & & & I(III) \\
\hline
\end{tabular}

* Solid volume equivalent of $94-1 \mathrm{~b}$ bag of portland cement $(=0.4782 \mathrm{cu} \mathrm{ft})$.

** Test Ages: I - 3, 28, 90, 360 days

II $-3,7,28,90,360,720$ days

III - flexural strength, 90 days

$\uparrow$ 1-1/2-in. maximum size coarse aggregate. All other aggregate is 1-in. maximum size. 
Table 2

Phase I Concrete Mixture Proportion Data

\begin{tabular}{|c|c|c|c|c|c|c|c|c|c|c|c|c|c|c|}
\hline $\begin{array}{c}\text { Mixture } \\
\text { No. } \\
\end{array}$ & $\begin{array}{c}\mathrm{CM}^{\star} \\
\text { Content } \\
\mathrm{ft}^{3} / \mathrm{yd}^{3} \\
\end{array}$ & $\begin{array}{c}\text { Percent } \\
\text { Fly Ash } \\
\text { Replacement } \\
\text { By Volume } \\
\end{array}$ & $\begin{array}{l}\text { Cement** } \\
\left(1 \mathrm{~b} / \mathrm{yd}^{3}\right) \\
\end{array}$ & $\begin{array}{l}\text { F1y Ash } \\
\left(1 \mathrm{~b} / \mathrm{yd}^{3}\right)\end{array}$ & $\begin{array}{c}\text { Water } \\
\left(1 \mathrm{~b} / \mathrm{yd}^{3}\right) \\
\end{array}$ & Type & $\begin{array}{l}\text { WRA }^{\dagger} \\
\begin{array}{l}\text { Amount } \\
\text { Added }\end{array} \\
\end{array}$ & Rate & $\begin{array}{l}\text { W/ } \mathrm{CM}^{++} \\
\text {By Wt }\end{array}$ & Sandf & $\begin{array}{c}\text { Sand/ } \\
\text { Aggregate } \\
\text { By Wt } \\
\end{array}$ & $\begin{array}{l}\text { Average } \\
\text { Slump, } \\
3 \text { Batches } \\
\text { (in.) }\end{array}$ & $\begin{array}{c}\text { Deformed } \\
\text { Steel } \\
\text { Fibers } \\
\left(1 \mathrm{~b} / \mathrm{yd}^{3}\right) \\
\end{array}$ & $\begin{array}{l}\text { Fiber } \\
\text { Length } \\
\text { (mm) } \\
\end{array}$ \\
\hline 25 & 2.630 & 35 & 336.1 & 132.9 & 256.8 & C & $23.5 \mathrm{oz}$ & $5.0 \mathrm{oz}$ & 0.548 & L & 0.55 & 2.33 & -- & -- \\
\hline 26 & 2.630 & 0 & 517.0 & -- & 222.1 & $\mathrm{H}$ & $14.21 \mathrm{~b}$ & $2.75 \%$ & 0.457 & L & 0.50 & 1.33 & - & -- \\
\hline 27 & 2.630 & 35 & 336.1 & 132.9 & 226.2 & H & $10.11 \mathrm{~b}$ & $3.0 \%$ & 0.482 & L & 0.50 & 1.25 & -- & -- \\
\hline $27 A \ddagger \ddagger$ & 2.630 & 35 & 336.1 & 132.9 & 238.5 & H & $10.11 \mathrm{~b}$ & $3.0 \%$ & 0.508 & L & 0.54 & -- & 84.0 & 50 \\
\hline 1 & 3.347 & 0 & 658.0 & -- & 316.2 & -- & - & - & 0.480 & $P$ & 0.44 & 2.83 & -- & - \\
\hline 2 & 3.347 & 20 & 526.4 & 96.8 & 316.2 & -- & -- & -- & 0.508 & $\mathrm{P}$ & 0.44 & 2.75 & -- & -- \\
\hline 3 & 3.347 & 35 & 427.9 & 169.3 & 316.2 & -- & - & -- & 0.529 & $P$ & 0.44 & 2.75 & -- & -- \\
\hline 4 & 3.347 & 50 & 329.0 & 241.8 & 316.2 & -- & - & -- & 0.554 & $\mathrm{P}$ & 0.44 & 2.75 & -- & - \\
\hline 5 & 3.347 & 0 & 658.0 & -- & 283.0 & C & 32.9 oz & $5.0 \mathrm{oz}$ & 0.432 & $\mathrm{P}$ & 0.44 & 2.58 & - & -- \\
\hline 6 & 3.347 & 20 & 526.4 & 96.8 & 283.0 & C & $31.2 \mathrm{oz}$ & $5.0 \mathrm{oz}$ & 0.457 & $\mathrm{P}$ & 0.44 & 2.58 & - & -- \\
\hline 7 & 3.347 & 35 & 427.7 & 169.3 & 283.1 & C & $29.8 \mathrm{oz}$ & $5.0 \mathrm{oz}$ & 0.476 & $\mathrm{P}$ & 0.44 & 2.67 & -- & -- \\
\hline 11 & 3.347 & 35 & 427.7 & 169.3 & 278.6 & C & $29.9 \mathrm{oz}$ & $5.0 \mathrm{oz}$ & 0.467 & L & 0.49 & 1.67 & 82.1 & 50 \\
\hline $7 \mathrm{~A}$ & 3.347 & 35 & 427.7 & 169.3 & 260.7 & C & $29.8 \mathrm{oz}$ & $5.0 \mathrm{oz}$ & 0.440 & L & 0.46 & 3.00 & - & -- \\
\hline 8 & 3.347 & $48 \S$ & 329.0 & 231.8 & 283.2 & C & $28.5 \mathrm{oz}$ & $5.0 \mathrm{oz}$ & 0.507 & L & 0.48 & 2.58 & -- & -- \\
\hline 13 & 3.347 & 0 & 658.0 & -- & 226.8 & $\mathrm{H}$ & $13.21 \mathrm{~b}$ & $2.0 \%$ & 0.364 & L & 0.48 & 2.50 & -- & -- \\
\hline 14 & 3.347 & 20 & 526.4 & 96.8 & 227.9 & H & $12.11 \mathrm{~b}$ & $2.3 \%$ & 0.385 & L & 0.48 & 2.67 & -- & -- \\
\hline 15 & 3.347 & 35 & 427.7 & 169.3 & 227.9 & H & $10.31 \mathrm{~b}$ & $2.4 \%$ & 0.402 & L & 0.48 & 2.50 & -- & - \\
\hline 16 & 3.347 & 50 & 329.0 & 241.8 & 231.8 & H & $8.21 \mathrm{~b}$ & $2.5 \%$ & 0.420 & L & 0.48 & 2.50 & -- & -- \\
\hline 9 & 4.065 & 35 & 519.3 & 205.6 & 268.0 & C & $36.2 \mathrm{oz}$ & $5.0 \mathrm{oz}$ & 0.372 & L & 0.44 & 3.00 & & \\
\hline 12 & 4.065 & 35 & 519.3 & 205.6 & 288.0 & $\mathrm{C}$ & $36.2 \mathrm{oz}$ & $5.0 \mathrm{oz}$ & 0.397 & L & 0.48 & 1.25 & 83.5 & 50 \\
\hline 17 & 4.065 & 0 & 799.0 & -- & 223.0 & $\mathrm{H}$ & $17.61 \mathrm{~b}$ & $2.2 \%$ & 0.280 & $\mathrm{~L}$ & 0.48 & 2.50 & -- & - \\
\hline $17 \mathrm{~A} \neq \ddagger$ & 4.065 & 0 & 799.0 & -- & 223.0 & $\mathrm{H}$ & $17.61 \mathrm{~b}$ & $2.2 \%$ & 0.280 & L & 0.48 & 2.50 & -- & -- \\
\hline 18 & 4.065 & 35 & 519.3 & 205.6 & 223.9 & H & $16.11 \mathrm{~b}$ & $3.1 \%$ & 0.331 & $\mathrm{~L}$ & 0.48 & 2.50 & -- & -- \\
\hline 24 & 4.065 & 35 & 519.3 & 205.6 & 246.9 & $\mathrm{H}$ & $14.01 \mathrm{~b}$ & $2.7 \%$ & 0.340 & $\mathrm{~L}$ & 0.50 & 1.75 & 86.9 & 50 \\
\hline $24 S \ddagger \ddagger$ & 4.065 & 35 & 519.3 & 205.6 & 246.9 & $\mathrm{H}$ & $14.01 \mathrm{~b}$ & $2.7 \%$ & 0.340 & $\mathrm{~L}$ & 0.50 & -- & 86.9 & 30 \\
\hline
\end{tabular}

(Continued) 
Table 2 (Concluded)

\begin{tabular}{|c|c|c|c|c|c|c|c|c|c|c|c|c|c|c|}
\hline $\begin{array}{c}\text { Mixture } \\
\text { No. } \\
\end{array}$ & $\begin{array}{c}\mathrm{CM}^{*} \\
\text { Content } \\
\mathrm{ft}^{3} / \mathrm{yd}^{3} \\
\end{array}$ & $\begin{array}{c}\text { Percent } \\
\text { Fly Ash } \\
\text { Replacement } \\
\text { By Volume } \\
\end{array}$ & $\begin{array}{l}\text { Cement }{ }^{* *} \\
\left(1 \mathrm{~b} / \mathrm{yd}^{3}\right) \\
\end{array}$ & $\begin{array}{l}\text { F1y Ash } \\
\left(1 \mathrm{~b} / \mathrm{yd}^{3}\right) \\
\end{array}$ & $\begin{array}{c}\begin{array}{c}\text { Water } \\
\left(1 \mathrm{~b} / \mathrm{yd}^{3}\right) \\
\end{array} \\
\end{array}$ & Type & $\begin{array}{l}\text { WRA }^{\dagger} \\
\text { Amount } \\
\text { Added }\end{array}$ & Rate & $\begin{array}{l}\text { W/ } \mathrm{CM}^{+\dagger} \\
\text { By Wt }\end{array}$ & Sand $\ddagger$ & $\begin{array}{c}\text { Sand/ } \\
\text { Aggregate } \\
\text { By Wt } \\
\end{array}$ & $\begin{array}{l}\text { Average } \\
\text { Slump, } \\
3 \text { Batches } \\
\text { (in.) } \\
\end{array}$ & $\begin{array}{c}\text { Deformed } \\
\text { Steel } \\
\text { Fibers } \\
\left(1 \mathrm{~b} / \mathrm{yd}^{3}\right) \\
\end{array}$ & $\begin{array}{l}\text { Fiber } \\
\text { Length } \\
(\mathrm{mm}) \\
\end{array}$ \\
\hline $23 \mathrm{~A}$ & 4.182 & 35 & 519.3 & 205.6 & 215.9 & H & $16.11 \mathrm{~b}$ & $3.1 \%$ & 0.320 & L & 0.47 & 2.67 & -- & -- \\
\hline 23 & 4.182 & 35 & 519.3 & 205.6 & 239.7 & $\mathrm{H}$ & $14.01 \mathrm{~b}$ & $2.7 \%$ & 0.331 & L & 0.51 & 2.50 & 85.0 & 50 \\
\hline 19 & 4.182 & 50 & 399.6 & 293.5 & 226.0 & $\mathrm{H}$ & $14.01 \mathrm{~b}$ & $3.5 \%$ & 0.346 & L & 0.47 & 2.58 & -- & - \\
\hline 10 & 4.920 & 35 & 610.9 & 241.8 & 280.0 & C & $42.6 \mathrm{oz}$ & $5.0 \mathrm{oz}$ & 0.330 & L & 0.42 & 2.75 & -- & -- \\
\hline $20 \neq \ddagger$ & 4.920 & 0 & 940.0 & - & 233.1 & $\mathrm{H}$ & $25.41 \mathrm{~b}$ & $2.7 \%$ & 0.275 & L & 0.52 & 3.00 & -- & -- \\
\hline 21 & 4.920 & 35 & 610.9 & 241.8 & 241.4 & $\mathrm{H}$ & $17.11 \mathrm{~b}$ & $2.8 \%$ & 0.300 & L & 0.52 & Flowing & -- & -- \\
\hline 22 & 4.920 & 50 & 470.0 & 345.4 & 231.5 & $\mathrm{H}$ & $27.01 \mathrm{~b}$ & $5.7 \%$ & 0.320 & L & 0.52 & Flowing & -- & -- \\
\hline
\end{tabular}

* Cementitious materials content by solid volume. Divide by 0.4782 to obtain $94-1 \mathrm{~b}$ bags.

** All cement used was RC-822(1) except where noted.

+ Water-reducing admixture Types $C$ - conventional added in fluid ounces per cwt of cement.

$\mathrm{H}$ - high-range added as percentage of cement mass in pounds.

$+\dagger$ Water-cementitious materials ratio by weight.

$\ddagger$ Sand: P - project.

L - Laboratory stock.

$\ddagger \ddagger$
5 Error found in mixture design, mixture No. 8. Amount of added fly ash is $101 \mathrm{~b} / \mathrm{yd} \mathrm{d}^{3} 1$ ess than needed for 50 percent replacement. 
Table 3

Cement Analysis

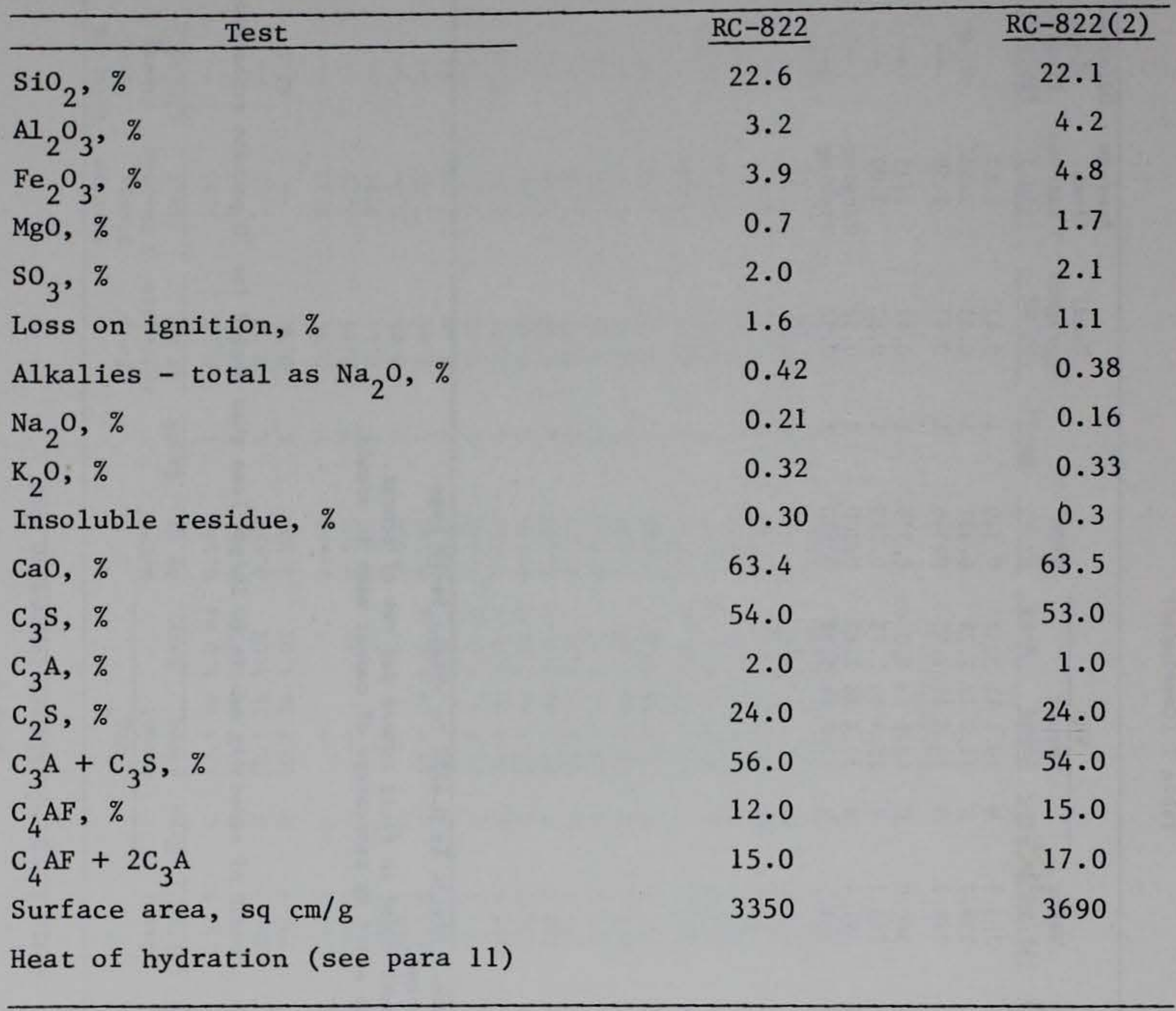


Table 4

Fly Ash Analysis

\begin{tabular}{lcc}
\hline \multicolumn{1}{c}{ Test } & $\mathrm{AD}-566$ & $\frac{\mathrm{AD}-566(2)}{2}$ \\
\cline { 2 - 2 } $\mathrm{SiO}_{2}+\mathrm{Al}_{2} \mathrm{O}_{3}+\mathrm{Fe}_{2} \mathrm{O}_{3}, \%$ & 89.2 & 87.7 \\
$\mathrm{MgO}_{\%}$ & 0.7 & 1.0 \\
$\mathrm{SO}_{3}, \%$ & 0.5 & 0.4 \\
Available alkalies, \% & 0.40 & 0.62 \\
Pozzolan strength, \% control & 95 & 94 \\
Autoclave expansion, \% & 0.01 & -0.02 \\
Moisture, \% & 0.1 & 0.28 \\
Loss on ignition, \% & 4.9 & 5.22 \\
Fineness, sq cm/cc & 7820 & 9400 \\
Lime pozzolan strength, psi & 1050 & 1360 \\
Water requirement, $\%$ of control & 100 & 105 \\
Specific gravity & 2.35 & 2.28 \\
\hline
\end{tabular}


Table 5

Sieve Analyses, Coarse Aggregate

Material: 1-in. maximum size crushed limestone,

CL-21 G-1(2) and (3)

Source: Martin Marietta Aggregates, Williamsport, MD

Sieve

Size

1 in.

$3 / 4$ in.

$1 / 2$ in.

$3 / 8$ in.

No. 4

No. 8

No. 16
Grading (Cum. Percent Passing)

$\frac{1 / 2-1 \text { in. }}{(2) \text { No. } 4-1 / 2 \text { in. }}$

$\begin{array}{rr}99 & 99 \\ 82 & 82 \\ 42 & 38 \\ 13 & 11 \\ 1 & 1\end{array}$

(1) (1)

$96 \quad 94$

$64 \quad 65$

83

(2) (1)

(1)

Material: 1-1/2-in. maximum size crushed limestone, CL-21 G-1 (1)

Source: Same as above

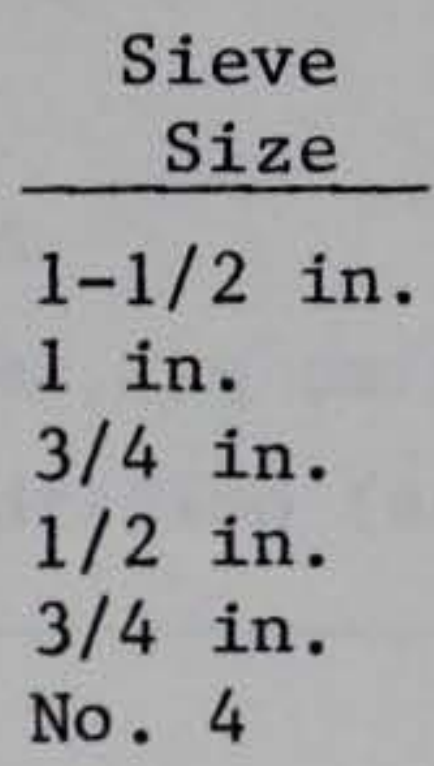

Grading (Cum. Percent Passing)

3/4-1-1/2 in. No. $4-3 / 4$ in.

98

39

3100

1 
Material: Project natural quartz sand, CL-21 S-1(2)

Source: Mt. Cydonia Sand Co.,

Fayetteville, PA

\begin{tabular}{l}
$\begin{array}{l}\text { Sieve } \\
\text { Size }\end{array}$ \\
\hline No. 4 \\
No. 8 \\
No. 16 \\
No. 30 \\
No. 50 \\
No. 100 \\
No. 200 \\
Pan
\end{tabular}

Cumulative Percent

\begin{tabular}{rrr}
\hline Ret. & & Pass. \\
\cline { 1 - 1 } 1.4 & & 98.6 \\
9.2 & & 90.8 \\
20.9 & & 79.1 \\
36.8 & & 63.2 \\
66.5 & & 33.5 \\
92.1 & & 7.9 \\
\hline$(98.5)$ & & 1.5 \\
$(100.0)$ & & 0
\end{tabular}

Fineness Modulus $=\underline{2.27}$

(No. 4 - No. 100)

Material: Laboratory stock natural sand, CL-20 S-1

Source: Arkadelphia Sand and Gravel Co., Arkadelphia, AR

\begin{tabular}{l}
$\begin{array}{l}\text { Sieve } \\
\text { Size }\end{array}$ \\
\hline No. 4 \\
No. 8 \\
No. 16 \\
No. 30 \\
No. 50 \\
No. 100 \\
No. 200 \\
Pan
\end{tabular}

\begin{tabular}{cr}
\multicolumn{2}{c}{ Cumulative Percent } \\
\hline Ret. & Pass. \\
3.7 & 96.3 \\
25.1 & 74.9 \\
41.5 & 58.5 \\
54.6 & 45.4 \\
82.3 & 17.7 \\
95.8 & 4.2 \\
\hline$(98.5)$ & 1.5 \\
$(100.0)$ & 0
\end{tabular}

Fineness Modulus $=3.03$

(No. 4 - No. 100) 
Table 7

Compressive Strengths Versus Age for Increasing Cementitious Material (CM) Contents

\begin{tabular}{|c|c|c|c|c|c|c|c|c|c|c|c|c|c|}
\hline \multirow{2}{*}{$\begin{array}{c}\text { Mixture } \\
\text { No. }\end{array}$} & \multirow{2}{*}{$\begin{array}{c}\mathrm{CM}^{*} \\
\text { Content } \\
\mathrm{ft} \mathrm{t}^{3} / \mathrm{yd}^{3} \\
\end{array}$} & \multirow{2}{*}{$\begin{array}{c}\text { Percent } \\
\text { Fly Ash } \\
\text { Replacement } \\
\text { By Volume } \\
\end{array}$} & \multirow{2}{*}{$\begin{array}{l}\text { W/ } \mathrm{CM}^{* *} \\
\text { By Wt }\end{array}$} & \multirow[b]{2}{*}{ WRA $^{\dagger}$} & \multirow{2}{*}{$\begin{array}{l}\text { Steel } \\
\text { Fiber } \\
\text { Length } \\
(\mathrm{mm}) \\
\end{array}$} & \multicolumn{2}{|c|}{$\frac{\text { Curing Conditiontt }}{\text { Moisture }}$} & \multicolumn{5}{|c|}{ Compressive Strength, psif } & \multirow[b]{2}{*}{2 year } \\
\hline & & & & & & ${ }^{\circ} \mathrm{F}$ & I - Immersed & 3 day & 7 day & 28 day & 90 day & 1 year & \\
\hline \multirow[t]{2}{*}{25} & 2.630 & 35 & 0.548 & C & -- & 73 & S & 1230 & -- & 3760 & 5540 & 7030 & -- \\
\hline & & & & & & 122 & $\mathrm{~s}$ & (2110) & - & (5120) & $(5400)$ & (5380) & -- \\
\hline \multirow[t]{2}{*}{26} & 2.630 & 0 & 0.457 & $\mathrm{H}$ & -- & 73 & $S$ & 3170 & -- & 6160 & 7060 & 8360 & - \\
\hline & & & & & & 122 & $\mathrm{~S}$ & $(4210)$ & -- & $(6650)$ & $(7280)$ & $(7560)$ & - \\
\hline \multirow[t]{2}{*}{27} & 2.630 & 35 & 0.482 & $\mathrm{H}$ & -- & 73 & $\mathrm{~s}$ & 1510 & -- & 4050 & 5720 & 7070 & - \\
\hline & & & & & & 122 & S & $(2360)$ & -- & $(4990)$ & $(5050)$ & $(5180)$ & -- \\
\hline \multirow[t]{2}{*}{$27 \mathrm{~A} \ddagger \ddagger$} & 2.630 & 35 & 0.508 & $\mathrm{H}$ & 50 & 73 & $\mathrm{~s}$ & -- & -- & 3580 & 5520 & - & -- \\
\hline & & & & & & 122 & -- & -- & -- & - & -- & - & -- \\
\hline \multirow[t]{2}{*}{1} & 3.347 & 0 & 0.480 & -- & -- & 73 & S & 3130 & -- & 5690 & 6650 & 7420 & 7640 \\
\hline & & & & & & 122 & S & $(4130)$ & - & (5980) & $(6300)$ & $(6760)$ & -- \\
\hline \multirow[t]{2}{*}{2} & 3.347 & 20 & 0.508 & -- & -- & 73 & $\mathrm{~s}$ & 2370 & -- & 5300 & 6730 & 7860 & 8030 \\
\hline & & & & & & 122 & $\mathrm{~s}$ & $(3310)$ & - & $(5840)$ & $(6140)$ & $(6100)$ & -- \\
\hline \multirow[t]{2}{*}{3} & 3.347 & 35 & 0.529 & -- & -- & 73 & S & 1540 & -- & 4260 & 6400 & 7540 & 7800 \\
\hline & & & & & & 122 & $\mathrm{~S}$ & (2490) & -- & (5380) & (5390) & (5420) & -- \\
\hline \multirow[t]{2}{*}{4} & 3.347 & 50 & 0.554 & -- & - & 73 & S & 960 & -- & 3070 & 4600 & 5810 & 6440 \\
\hline & & & & & & 122 & $\mathrm{~S}$ & $(1730)$ & -- & $(4160)$ & $(4260)$ & (4380) & -- \\
\hline \multirow[t]{2}{*}{5} & 3.347 & 0 & 0.432 & C & -- & 73 & $\mathrm{~s}$ & 3340 & -- & 6370 & 7140 & 8370 & 9170 \\
\hline & & & & & & 122 & S & $(4610)$ & -- & (6390) & $(7040)$ & (7950) & -- \\
\hline \multirow[t]{2}{*}{6} & 3.347 & 20 & 0.457 & C & -- & 73 & $\mathrm{~S}$ & 2420 & -- & 5680 & 7040 & 8350 & 8760 \\
\hline & & & & & & 122 & $\mathrm{~S}$ & $(3470)$ & - & $(6200)$ & $(6450)$ & $(6730)$ & - \\
\hline \multirow[t]{4}{*}{7} & 3.347 & 35 & 0.476 & C & - & 73 & S & 1840 & 3160 & 5040 & 7480 & 8520 & 9010 \\
\hline & & & & & & 122 & $\mathrm{~S}$ & $(2720)$ & (4840) & (5970) & (6580) & (6510) & (6720) \\
\hline & & & & & & 73 & I & 1860 & 3200 & 5260 & 7460 & 8670 & 8850 \\
\hline & & & & & & 122 & I & (2740) & $(4460)$ & $(6580)$ & (7140) & $(7000)$ & (7820) \\
\hline \multirow[t]{2}{*}{11} & 3.347 & 35 & 0.467 & C & 50 & 73 & S & 1980 & -- & 5050 & 6470 & 8220 & -- \\
\hline & & & & & & 122 & S & (3290) & - & (6220) & $(6260)$ & (6420) & -- \\
\hline
\end{tabular}

(Continued) 
Table 7 (Continued)

\begin{tabular}{|c|c|c|c|c|c|c|c|c|c|c|c|c|c|}
\hline \multirow{2}{*}{$\begin{array}{c}\text { Mixture } \\
\text { No. }\end{array}$} & \multirow{2}{*}{$\begin{array}{c}\mathrm{CM}^{*} \\
\text { Content } \\
\mathrm{ft}^{3} / \mathrm{yd}^{3} \\
\end{array}$} & \multirow{2}{*}{$\begin{array}{c}\text { Percent } \\
\text { Fly Ash } \\
\text { Replacement } \\
\text { By Volume } \\
\end{array}$} & \multirow{2}{*}{$\begin{array}{l}\text { W/CM** } \\
\text { By Wt }\end{array}$} & \multirow[b]{2}{*}{$\underline{\text { WRA }^{\dagger}}$} & \multirow{2}{*}{$\begin{array}{l}\text { Steel } \\
\text { Fiber } \\
\text { Length } \\
(\mathrm{mm})\end{array}$} & \multirow{2}{*}{$\frac{\text { Temp. }}{\mathrm{O}_{\mathrm{F}}}$} & \multirow{2}{*}{$\begin{array}{l}\text { Moisture } \\
\mathrm{S}-\text { Sealed } \\
\text { I- Immersed }\end{array}$} & \multicolumn{5}{|c|}{ Compressive Strength, psif } & \\
\hline & & & & & & & & 3 day & 7 day & 28 day & 90 day & 1 year & 2 year \\
\hline \multirow{2}{*}{$7 \mathrm{~A}$} & 3.347 & 35 & 0.440 & C & -- & 73 & $S$ & 1950 & -- & 5050 & 6990 & 8320 & -- \\
\hline & & & & & & 122 & $\mathrm{~S}$ & $(3130)$ & - & $(6100)$ & $(6370)$ & $(6420)$ & - \\
\hline \multirow[t]{2}{*}{8} & 3.347 & 50 & 0.507 & C & - & 73 & S & 1110 & -- & 3780 & 5520 & 6950 & 7,630 \\
\hline & & & & & & 122 & S & $(2010)$ & -- & (5040) & (5240) & (5330) & -- \\
\hline \multirow[t]{4}{*}{13} & 3.347 & 0 & 0.364 & H & -- & 73 & $\mathrm{~S}$ & 4720 & 6090 & 7350 & 8600 & 10,480 & 10,310 \\
\hline & & & & & & 122 & S & $(6100)$ & $(7010)$ & $(8270)$ & $(8800)$ & $(10,160)$ & $(11,340)$ \\
\hline & & & & & & 73 & I & 5010 & 6470 & 7890 & 9150 & 11,040 & 10,903 \\
\hline & & & & & & 122 & I & $(6140)$ & $(7130)$ & $(8760)$ & $(9610)$ & $(10,850)$ & $(11,530)$ \\
\hline \multirow[t]{2}{*}{14} & 3.347 & 20 & 0.385 & $\mathrm{H}$ & -- & 73 & S & 3550 & -- & 6790 & 8820 & 10,220 & -- \\
\hline & & & & & & 122 & $S$ & $(4940)$ & -- & $(8160)$ & $(8100)$ & $(8410)$ & -- \\
\hline \multirow[t]{4}{*}{15} & 3.347 & 35 & 0.402 & H & -- & 73 & S & 2340 & 3570 & 5730 & 7620 & 8470 & 8,636 \\
\hline & & & & & & 122 & S & $(3540)$ & $(5720)$ & $(6690)$ & $(6660)$ & (6540) & $(6,510)$ \\
\hline & & & & & & 73 & I & 2340 & 3730 & 6160 & 8510 & 9930 & 9,590 \\
\hline & & & & & & 122 & I & $(3390)$ & $(5590)$ & $(7350)$ & $(7540)$ & $(7620)$ & $(7,800)$ \\
\hline \multirow[t]{2}{*}{16} & 3.347 & 50 & 0.420 & H & -- & 73 & S & 1600 & -- & 4960 & 6590 & 7620 & 7,930 \\
\hline & & & & & & 122 & $\mathrm{~S}$ & $(2800)$ & - & $(5680)$ & $(5680)$ & $(5920)$ & -- \\
\hline \multirow[t]{2}{*}{9} & 4.065 & 35 & 0.372 & C & -- & 73 & S & 3000 & - & 7340 & 8520 & 9620 & -- \\
\hline & & & & & & 122 & $S$ & $(4470)$ & -- & $(7800)$ & $(7910)$ & $(7910)$ & -- \\
\hline \multirow[t]{2}{*}{12} & 4.065 & 35 & 0.397 & C & 50 & 73 & S & 2618 & -- & 6060 & 8030 & 9880 & -- \\
\hline & & & & & & 122 & S & $(4020)$ & -- & $(7350)$ & (7580) & $(7690)$ & -- \\
\hline \multirow[t]{2}{*}{17} & 4.065 & 0 & 0.280 & H & -- & 73 & $\mathrm{~s}$ & 5160 & -- & 8840 & 9780 & 10,920 & 12,020 \\
\hline & & & & & & 122 & S & $(6810)$ & -- & $(9420)$ & $(10,350)$ & $(10,220)$ & -- \\
\hline \multirow[t]{2}{*}{$17 A \neq \ddagger$} & 4.065 & 0 & 0.280 & H & -- & 73 & S & 6080 & -- & 8570 & 9950 & 11,440 & - \\
\hline & & & & & & 122 & $S$ & $(7180)$ & -- & $(9150)$ & $(10,437)$ & $(11,390)$ & -- \\
\hline \multirow[t]{4}{*}{18} & 4.065 & 35 & 0.331 & H & -- & 73 & S & 3620 & 4940 & 6980 & 8400 & 9120 & 9,400 \\
\hline & & & & & & 122 & S & $(5000)$ & $(6930)$ & (7720) & $(7620)$ & $(7690)$ & $(7,910)$ \\
\hline & & & & & & 73 & I & 3920 & 5620 & 7980 & 9890 & 10,270 & 11,010 \\
\hline & & & & & & 122 & I & $(5020)$ & $(7320)$ & $(8510)$ & $(8870)$ & $(8700)$ & $(9,680)$ \\
\hline \multirow[t]{2}{*}{24} & 4.065 & 35 & 0.340 & H & 50 & 73 & $\mathrm{~S}$ & 3360 & -- & 6540 & 8520 & 9670 & -- \\
\hline & & & & & & 122 & S & $(4910)$ & -- & $(7760)$ & $(7910)$ & $(8280)$ & - \\
\hline
\end{tabular}

(Continued) 
Table 7 (Concluded)

\begin{tabular}{|c|c|c|c|c|c|c|c|c|c|c|c|c|c|}
\hline \multirow{2}{*}{$\begin{array}{l}\text { Mixture } \\
\text { No. } \\
\end{array}$} & \multirow{2}{*}{$\begin{array}{c}\mathrm{CM}^{*} \\
\text { Content } \\
\mathrm{ft}^{3} / \mathrm{yd}^{3} \\
\end{array}$} & \multirow{2}{*}{$\begin{array}{c}\text { Percent } \\
\text { Fly Ash } \\
\text { Replacement } \\
\text { By Volume } \\
\end{array}$} & \multirow{2}{*}{$\begin{array}{l}\text { W/CM** } \\
\text { By Wt } \\
\end{array}$} & \multirow[b]{2}{*}{$\mathrm{WRA}^{\dagger}$} & \multirow{2}{*}{$\begin{array}{l}\text { Steel } \\
\text { Fiber } \\
\text { Length } \\
(\mathrm{mm}) \\
\end{array}$} & $\begin{array}{l}\text { Curing } \\
\text { Temp. }\end{array}$ & 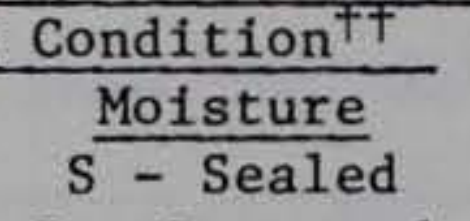 & \multicolumn{6}{|c|}{ Compressive Strength, psif } \\
\hline & & & & & & $\mathrm{OF}_{\mathrm{F}}$ & I - Immersed & 3 day & 7 day & 28 day & 90 day & 1 year & 2 year \\
\hline $24 S \ddagger \ddagger$ & 4.065 & 35 & 0.340 & H & 30 & $\begin{array}{r}73 \\
122\end{array}$ & $\begin{array}{l}\mathrm{S} \\
\mathrm{s}\end{array}$ & $\begin{array}{c}3190 \\
(5070)\end{array}$ & -- & $\begin{array}{c}6400 \\
(8220)\end{array}$ & $\begin{array}{c}8590 \\
(8580)\end{array}$ & $\begin{array}{l}10,100 \\
(8510)\end{array}$ & -- \\
\hline $23 \mathrm{~A}$ & 4.065 & 35 & 0.320 & H & -- & $\begin{array}{r}73 \\
122\end{array}$ & $\begin{array}{l}\mathrm{S} \\
\mathrm{S}\end{array}$ & $\begin{array}{c}3850 \\
(5210)\end{array}$ & -- & $\begin{array}{l}7540 \\
(8310)\end{array}$ & $\begin{array}{c}9130 \\
(8260)\end{array}$ & $\begin{array}{l}10,210 \\
(8440)\end{array}$ & $\overline{--}$ \\
\hline 23 & 4.065 & 35 & 0.331 & н & 50 & $\begin{array}{r}73 \\
122\end{array}$ & $\begin{array}{l}\mathrm{S} \\
\mathrm{S}\end{array}$ & $\begin{array}{c}3460 \\
(5220)\end{array}$ & $\overline{-}$ & $\begin{array}{c}6570 \\
(7940)\end{array}$ & $\begin{array}{c}8610 \\
(8130)\end{array}$ & $\begin{array}{c}9970 \\
(8300)\end{array}$ & - \\
\hline 19 & 4.065 & 50 & 0.346 & н & -- & $\begin{array}{r}73 \\
122\end{array}$ & $\begin{array}{l}\mathrm{S} \\
\mathrm{S}\end{array}$ & $\begin{array}{c}2480 \\
(4100)\end{array}$ & -- & $\begin{array}{c}6150 \\
(6970)\end{array}$ & $\begin{array}{l}7790 \\
(7170)\end{array}$ & $\begin{array}{c}8520 \\
(6930)\end{array}$ & $\begin{array}{c}8840 \\
--\end{array}$ \\
\hline 10 & 4.782 & 35 & 0.330 & c & -- & $\begin{array}{r}73 \\
122\end{array}$ & $\begin{array}{l}\mathrm{S} \\
\mathrm{S}\end{array}$ & $\begin{array}{c}3250 \\
(4980)\end{array}$ & -- & $\begin{array}{c}7140 \\
(8190)\end{array}$ & $\begin{array}{c}9280 \\
(8290)\end{array}$ & $\begin{array}{l}10,680 \\
(8540)\end{array}$ & -- \\
\hline 20 & 4.782 & 0 & 0.275 & $\mathrm{H}$ & -- & $\begin{array}{r}73 \\
122 \\
73 \\
122\end{array}$ & $\begin{array}{l}\text { S } \\
\text { S } \\
\text { I } \\
\text { I }\end{array}$ & $\begin{array}{c}6540 \\
(8000) \\
6960 \\
(7570)\end{array}$ & $\begin{array}{c}8070 \\
(9240) \\
8090 \\
(8450)\end{array}$ & $\begin{array}{c}9662 \\
(10,020) \\
10,310 \\
(10,610)\end{array}$ & $\begin{array}{c}9770 \\
(11,250) \\
11,590 \\
(11,810)\end{array}$ & $\begin{array}{c}12,250 \\
(11,100) \\
11,590 \\
(11,580)\end{array}$ & $\begin{array}{c}10,840 \\
(11,460) \\
11,300 \\
(11,480)\end{array}$ \\
\hline 21 & 4.782 & 35 & 0.300 & H & -- & $\begin{array}{r}73 \\
122 \\
73\end{array}$ & S & $\begin{array}{c}3640 \\
(5220) \\
3790\end{array}$ & $\begin{array}{c}4760 \\
(6930) \\
5320\end{array}$ & $\begin{array}{c}6640 \\
(7750) \\
7820\end{array}$ & $\begin{array}{c}8520 \\
(8240) \\
9010\end{array}$ & $\begin{array}{c}9480 \\
(8290) \\
11,480\end{array}$ & $\begin{array}{r}8160 \\
(7130) \\
11,080\end{array}$ \\
\hline & & & & & & 122 & I & $(4800)$ & $(7300)$ & $(8930)$ & $(9060)$ & $(9350)$ & $(9000)$ \\
\hline 22 & 4.782 & 50 & 0.320 & н & - & $\begin{array}{r}73 \\
122\end{array}$ & $\begin{array}{l}\mathrm{S} \\
\mathrm{s}\end{array}$ & $\begin{array}{c}2790 \\
(4840)\end{array}$ & -- & $\begin{array}{c}6200 \\
(7750)\end{array}$ & $\begin{array}{c}8220 \\
(8520)\end{array}$ & $\begin{array}{c}9803 \\
(8840)\end{array}$ & -- \\
\hline
\end{tabular}

* Cementitious materials content by volume. Divide by 0.4782 to obtain solid volume in $94-1 b$ bags.

** Water-cementitious materials ratio.

+ Water-reducing admixture: C - conventional, H - high range.

it Curing condition: S - sealed, I - immersed.

$\ddagger$ Values represent average strengths of three cylinders, one each from three batches.

¥† Batched with RC-822(2) cement. 
Table 8

Compressive Strength Versus Age for Decreasing Water/Cementitious Materials Ratio

\begin{tabular}{|c|c|c|c|c|c|c|c|c|c|c|c|c|c|}
\hline \multirow{2}{*}{$\begin{array}{l}\text { Mixture } \\
\text { No. } \\
\end{array}$} & \multirow{2}{*}{ 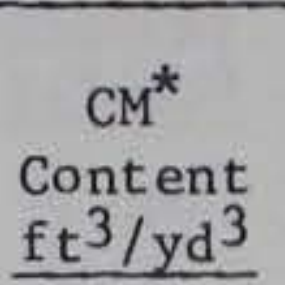 } & \multirow{2}{*}{$\begin{array}{c}\text { Percent } \\
\text { Fly Ash } \\
\text { Replacement } \\
\text { By Volume } \\
\end{array}$} & \multirow{2}{*}{$\begin{array}{l}\mathrm{W} / \mathrm{CM}^{* *} \\
\text { By Wt}\end{array}$} & \multirow[b]{2}{*}{ WRA $^{\dagger}$} & \multirow{2}{*}{$\begin{array}{l}\text { Steel } \\
\text { Fiber } \\
\text { Length } \\
(\mathrm{mm}) \\
\end{array}$} & Curing & $\frac{\text { Condition }}{\frac{\text { Moisture }}{s-\text { Sealed }}}$ & & Comp & ressive & Strength & psit & \\
\hline & & & & & & & $\underline{I}$ - Immersed & 3 day & 7 day & 28 day & 90 day & 1 year & 2 year \\
\hline 4 & 3.347 & 50 & 0.554 & -- & -- & 73 & S & $\begin{array}{l}960 \\
(1730)\end{array}$ & -- & 3070 & 4600 & 5810 & 6440 \\
\hline 25 & 2.630 & 35 & 0.548 & c & -- & $\begin{array}{r}73 \\
122\end{array}$ & S & $\begin{array}{c}1230 \\
(2110)\end{array}$ & - & $\begin{array}{c}3760 \\
(5120)\end{array}$ & $\begin{array}{c}5540 \\
(5400)\end{array}$ & $\begin{array}{c}7030 \\
(5380)\end{array}$ & - \\
\hline 3 & 3.347 & 35 & 0.529 & -- & -- & $\begin{array}{r}73 \\
122\end{array}$ & $\begin{array}{l}S \\
S\end{array}$ & $\begin{array}{c}1540 \\
(2490)\end{array}$ & -- & $\begin{array}{c}4260 \\
(5380)\end{array}$ & $\begin{array}{c}6400 \\
(5390)\end{array}$ & $\begin{array}{c}7540 \\
(5420)\end{array}$ & 7800 \\
\hline 2 & 3.347 & 20 & 0.508 & -- & -- & $\begin{array}{r}73 \\
122\end{array}$ & $\begin{array}{l}\mathrm{S} \\
\mathrm{S}\end{array}$ & $\begin{array}{c}2370 \\
(3310)\end{array}$ & -- & $\begin{array}{c}5300 \\
(5840)\end{array}$ & $\begin{array}{c}6730 \\
(6140)\end{array}$ & $\begin{array}{c}7860 \\
(6100)\end{array}$ & $\begin{array}{r}8030 \\
--\end{array}$ \\
\hline $27 \mathrm{~A} \ddagger \ddagger$ & 2.630 & 35 & 0.508 & $\mathrm{H}$ & 50 & $\begin{array}{r}73 \\
122\end{array}$ & $\begin{array}{l}S \\
S\end{array}$ & -- & -- & $\begin{array}{c}3580 \\
--\end{array}$ & $\begin{array}{c}5520 \\
--\end{array}$ & -- & -- \\
\hline 8 & 3.347 & 50 & 0.507 & C & - & $\begin{array}{r}73 \\
122\end{array}$ & $\begin{array}{l}S \\
S\end{array}$ & $\begin{array}{c}1110 \\
(2010)\end{array}$ & -- & $\begin{array}{c}3780 \\
(5040)\end{array}$ & $\begin{array}{c}5520 \\
(5240)\end{array}$ & $\begin{array}{c}6950 \\
(5330)\end{array}$ & $\begin{array}{r}7630 \\
--\end{array}$ \\
\hline 27 & 2.630 & 35 & 0.482 & $\mathrm{H}$ & -- & $\begin{array}{r}73 \\
122\end{array}$ & $\begin{array}{l}S \\
S\end{array}$ & $\begin{array}{c}1510 \\
(2360)\end{array}$ & -- & $\begin{array}{c}4050 \\
(4990)\end{array}$ & $\begin{array}{c}5720 \\
(5050)\end{array}$ & $\begin{array}{c}7070 \\
(5180)\end{array}$ & -- \\
\hline 1 & 3.347 & 0 & 0.480 & - & -- & $\begin{array}{r}73 \\
122\end{array}$ & $\begin{array}{l}\mathrm{S} \\
\mathrm{S}\end{array}$ & $\begin{array}{c}3130 \\
(4130)\end{array}$ & -- & $\begin{array}{c}5690 \\
(5980)\end{array}$ & $\begin{array}{c}6650 \\
(6300)\end{array}$ & $\begin{array}{c}7420 \\
(6760)\end{array}$ & $\begin{array}{r}7640 \\
--\end{array}$ \\
\hline 7 & 3.347 & 35 & 0.476 & C & -- & $\begin{array}{r}73 \\
122 \\
73 \\
122\end{array}$ & $\begin{array}{l}\text { S } \\
\text { S } \\
\text { I } \\
\text { I }\end{array}$ & $\begin{array}{c}1840 \\
(2720) \\
1860 \\
(2740)\end{array}$ & $\begin{array}{c}3160 \\
(4840) \\
3200 \\
(4460)\end{array}$ & $\begin{array}{c}5040 \\
(5970) \\
5260 \\
(6580)\end{array}$ & $\begin{array}{c}7480 \\
(6580) \\
7460 \\
(7140)\end{array}$ & $\begin{array}{c}8520 \\
(6510) \\
8670 \\
(7000)\end{array}$ & $\begin{array}{c}9010 \\
(6720) \\
8850 \\
(7820)\end{array}$ \\
\hline 11 & 3.347 & 35 & 0.467 & C & 50 & $\begin{array}{r}73 \\
122\end{array}$ & $\begin{array}{l}\mathrm{S} \\
\mathrm{S}\end{array}$ & $\begin{array}{c}1980 \\
(3290)\end{array}$ & -- & $\begin{array}{c}5050 \\
(6220)\end{array}$ & $\begin{array}{c}6470 \\
(6260)\end{array}$ & $\begin{array}{c}8220 \\
(6420)\end{array}$ & -- \\
\hline 6 & 3.347 & 20 & 0.457 & C & - & $\begin{array}{r}73 \\
122\end{array}$ & S & $\begin{array}{c}2420 \\
(3470)\end{array}$ & -- & $\begin{array}{c}5680 \\
(6200)\end{array}$ & $\begin{array}{c}7040 \\
(6450)\end{array}$ & $\begin{array}{c}8350 \\
(6730)\end{array}$ & $\begin{array}{r}8760 \\
--\end{array}$ \\
\hline 26 & 2.630 & 0 & 0.457 & $\mathrm{H}$ & - & $\begin{array}{r}73 \\
122\end{array}$ & S & $\begin{array}{c}3170 \\
(4210)\end{array}$ & -- & $\begin{array}{c}6160 \\
(6650)\end{array}$ & $\begin{array}{c}7060 \\
(7280)\end{array}$ & $\begin{array}{c}8360 \\
(7560)\end{array}$ & -- \\
\hline
\end{tabular}

(Continued) 
Table 8 (Continued)

\begin{tabular}{|c|c|c|c|c|c|c|c|c|c|c|c|c|c|}
\hline \multirow{2}{*}{$\begin{array}{l}\text { Mixture } \\
\text { No. } \\
\end{array}$} & \multirow{2}{*}{$\begin{array}{c}\mathrm{CM}^{*} \\
\text { Content } \\
\mathrm{ft}^{3} / \mathrm{yd}^{3} \\
\end{array}$} & \multirow{2}{*}{$\begin{array}{c}\text { Percent } \\
\text { Fly Ash } \\
\text { Replacement } \\
\text { By Volume } \\
\end{array}$} & \multirow{2}{*}{$\begin{array}{l}\mathrm{W} / \mathrm{CM}^{* *} \\
\text { By Wt }\end{array}$} & \multirow[b]{2}{*}{$\mathrm{WRA}^{+}$} & \multirow{2}{*}{$\begin{array}{l}\text { Steel } \\
\text { Fiber } \\
\text { Length } \\
(\mathrm{mm}) \\
\end{array}$} & \multirow{2}{*}{$\frac{\text { Temp. }}{\mathrm{O}_{\mathrm{F}}}$} & \multirow{2}{*}{$\begin{array}{c}\text { Moisture } \\
\text { S-Sealed } \\
\text { I - Immersed }\end{array}$} & \multicolumn{6}{|c|}{ Compressive Strength, psif } \\
\hline & & & & & & & & 3 day & 7 day & 28 day & 90 day & 1 year & 2 year \\
\hline $7 \mathrm{~A}$ & 3.347 & 35 & 0.440 & C & -- & 73 & $\mathrm{~s}$ & 1950 & -- & 5050 & 6990 & 8320 & -- \\
\hline & & & & & & 122 & s & $(3130)$ & -- & $(6100)$ & $(6370)$ & $(6420)$ & -- \\
\hline 5 & 3.347 & 0 & 0.432 & C & -- & 73 & s & 3340 & -- & 6370 & 7140 & 8370 & 9170 \\
\hline & & & & & & 122 & $\mathrm{~s}$ & $(4610)$ & -- & $(6390)$ & $(7040)$ & $(7950)$ & -- \\
\hline 16 & 3.347 & 50 & 0.420 & $\mathrm{H}$ & -- & 73 & $\mathrm{~s}$ & 1600 & -- & 4960 & 6590 & 7620 & 7930 \\
\hline & & & & & & 122 & $\mathrm{~s}$ & $(2800)$ & -- & $(5680)$ & $(5680)$ & $(5920)$ & - \\
\hline 15 & 3.347 & 35 & 0.402 & $\mathrm{H}$ & -- & 73 & S & 2340 & 3570 & 5730 & 7620 & 8470 & 8630 \\
\hline & & & & & & 122 & S & $(3540)$ & $(5720)$ & $(6690)$ & $(6660)$ & $(6540)$ & 6510 \\
\hline & & & & & & 73 & I & 2340 & 3730 & 6160 & 8510 & 9930 & 9590 \\
\hline & & & & & & 122 & I & $(3390)$ & $(5590)$ & $(7350)$ & $(7540)$ & $(7620)$ & 7800 \\
\hline 12 & 4.065 & 35 & 0.397 & C & 50 & 73 & S & 2620 & -- & 6060 & 8030 & 9880 & - \\
\hline & & & & & & 122 & $\mathrm{~S}$ & $(4020)$ & -- & $(7350)$ & $(7580)$ & $(7690)$ & -- \\
\hline 14 & 3.347 & 20 & 0.385 & H & -- & 73 & S & 3550 & -- & 6790 & 8820 & 10,220 & 9920 \\
\hline & & & & & & 122 & S & $(4940)$ & -- & $(8160)$ & $(8100)$ & $(8410)$ & -- \\
\hline 9 & 4.065 & 35 & 0.372 & C & -- & 73 & $\mathrm{~S}$ & 3000 & -- & 7340 & 8520 & 9620 & -- \\
\hline & & & & & & 122 & $\mathrm{~S}$ & $(4470)$ & -- & $(7800)$ & $(7910)$ & $(7910)$ & -- \\
\hline 13 & 3.347 & 0 & 0.364 & H & -- & 73 & S & 4720 & 6090 & 7350 & 8600 & 10,480 & 10,310 \\
\hline & & & & & & 122 & S & $(6100)$ & $(7010)$ & $(8270)$ & $(8800)$ & $(10,160)$ & $(11,340)$ \\
\hline & & & & & & 73 & I & 5010 & 6470 & 7890 & 9150 & 11,040 & 10,900 \\
\hline & & & & & & 122 & I & $(6140)$ & $(7130)$ & $(8760)$ & $(9610)$ & $(10,850)$ & $(11,530)$ \\
\hline 19 & 4.065 & 50 & 0.346 & $\mathrm{H}$ & -- & 73 & S & 2480 & -- & 6150 & 7790 & 8520 & 8840 \\
\hline & & & & & & 122 & S & $(4100)$ & -- & $(6970)$ & $(7170)$ & $(6930)$ & -- \\
\hline 24 & 4.065 & 35 & 0.340 & $\mathrm{H}$ & 50 & 73 & S & 3360 & -- & 6540 & 8520 & 9670 & -- \\
\hline & & & & & & 122 & S & $(4910)$ & -- & $(7760)$ & $(7910)$ & $(8280)$ & -- \\
\hline $24 s \ddagger \ddagger$ & 4.065 & 35 & 0.340 & $\mathrm{H}$ & 30 & 73 & S & 3190 & -- & 6400 & 8590 & & -- \\
\hline & & & & & & 122 & S & $(5070)$ & -- & $(8220)$ & $(8580)$ & & -- \\
\hline 18 & 4.065 & 35 & 0.331 & $\mathrm{H}$ & -- & 73 & S & 3620 & 4940 & 6980 & 8400 & 9120 & 9400 \\
\hline & & & & & & 122 & $\mathrm{~S}$ & $(5000)$ & $(6930)$ & $(7720)$ & $(7620)$ & $(7690)$ & $(7910)$ \\
\hline & & & & & & 73 & I & 3920 & 5620 & 7980 & 9890 & 10,270 & 11,010 \\
\hline & & & & & & 122 & I & $(5020)$ & $(7320)$ & $(8510)$ & $(8870)$ & $(8700)$ & $(9680)$ \\
\hline
\end{tabular}

(Continued) 
Table 8 (Concluded)

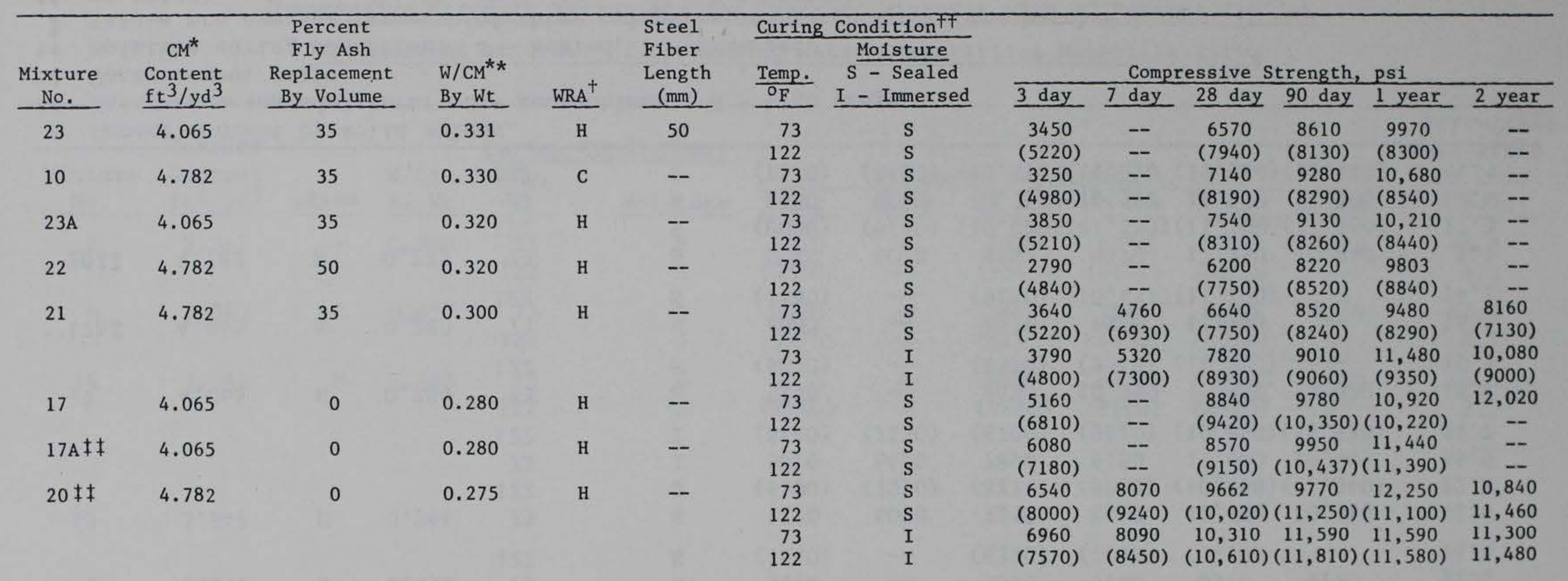

* Cementitious materials content by volume. Divide by 0.4782 to obtain solid volume in $94-1 b$ bags.

** Water-cementitious materials ratio.

+ Water-reducing admixture: C - conventional, H - high range.

if Curing condition: S - sealed, I - immersed.

$\ddagger$ Values represent average strengths of three cylinders, one each from three batches.

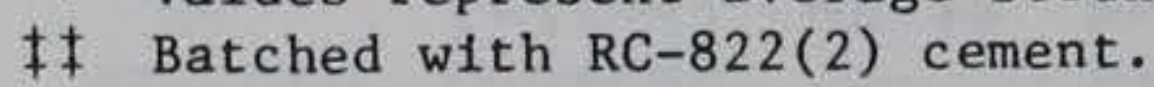


Table 9

Compressive Strengths Versus Age for Concrete Mixtures with No Fly Ash

in Order of Decreasing Water-Cement Ratio

\begin{tabular}{|c|c|c|c|c|c|c|c|c|c|c|c|c|}
\hline \multirow[b]{2}{*}{$\begin{array}{c}\text { Mixture } \\
\text { No. }\end{array}$} & \multirow{2}{*}{$\begin{array}{l}\text { Cement* } \\
\text { Content } \\
\mathrm{ft}^{3} / \mathrm{yd}^{3} \\
\end{array}$} & \multirow[b]{2}{*}{ WRA** } & \multirow[b]{2}{*}{$\begin{array}{l}\mathrm{W} / \mathrm{Ci} \\
\text { By Wt }\end{array}$} & \multicolumn{2}{|c|}{ Curing Conditiontt } & \multirow{2}{*}{\multicolumn{6}{|c|}{ Compressive Strength, psif }} & \multirow{2}{*}{$\begin{array}{c}\text { Strengthई } \\
\text { Gain After } \\
28 \text { Days } \\
\text { Percent }\end{array}$} \\
\hline & & & & $\frac{\text { Temp. }}{\mathrm{oF}}$ & Moisture & & & & & & & \\
\hline 1 & 3.347 & - & 0.480 & $\begin{array}{r}73 \\
122\end{array}$ & $\begin{array}{l}\mathrm{S} \\
\mathrm{S}\end{array}$ & $\begin{array}{c}3130 \\
(4130)\end{array}$ & -- & $\begin{array}{c}5690 \\
(5980)\end{array}$ & $\begin{array}{c}6650 \\
(6300)\end{array}$ & $\begin{array}{c}7420 \\
(6760)\end{array}$ & 7640 & $\begin{array}{l}30.4 \\
13.0\end{array}$ \\
\hline 26 & 2.630 & $\mathrm{H}$ & 0.457 & $\begin{array}{r}73 \\
122\end{array}$ & $\begin{array}{l}\mathrm{S} \\
\mathrm{S}\end{array}$ & $\begin{array}{c}3170 \\
(4210)\end{array}$ & -- & $\begin{array}{c}6160 \\
(6650)\end{array}$ & $\begin{array}{c}7060 \\
(7280)\end{array}$ & $\begin{array}{c}8360 \\
(7560)\end{array}$ & -- & $\begin{array}{l}35.7 \\
13.6\end{array}$ \\
\hline 5 & 3.347 & C & 0.432 & $\begin{array}{r}73 \\
122\end{array}$ & $\begin{array}{l}\mathrm{S} \\
\mathrm{S}\end{array}$ & $\begin{array}{c}3340 \\
(4610)\end{array}$ & -- & $\begin{array}{c}6370 \\
(6390)\end{array}$ & $\begin{array}{c}7140 \\
(7040)\end{array}$ & $\begin{array}{c}8370 \\
(7950)\end{array}$ & $\begin{array}{c}9170 \\
--\end{array}$ & $\begin{array}{l}31.4 \\
24.4\end{array}$ \\
\hline 13 & 3.347 & $\mathrm{H}$ & 0.364 & $\begin{array}{r}73 \\
122 \\
73 \\
122\end{array}$ & $\begin{array}{l}\text { S } \\
\text { S } \\
\text { I } \\
\text { I }\end{array}$ & $\begin{array}{c}4720 \\
(6100) \\
5010 \\
(6140)\end{array}$ & $\begin{array}{c}6090 \\
(7010) \\
6470 \\
(7130)\end{array}$ & $\begin{array}{c}7350 \\
(8270) \\
7890 \\
(8700)\end{array}$ & $\begin{array}{c}8600 \\
(8800) \\
9150 \\
(9610)\end{array}$ & $\begin{array}{c}10,480 \\
(10,160) \\
11,040 \\
(10,850)\end{array}$ & $\begin{array}{c}10,310 \\
(11,340) \\
10,903 \\
(11,530)\end{array}$ & $\begin{array}{l}42.6 \\
22.8 \\
39.9 \\
24.7\end{array}$ \\
\hline 17 & 4.065 & $\mathrm{H}$ & 0.280 & $\begin{array}{r}73 \\
122\end{array}$ & $\begin{array}{l}\mathrm{S} \\
\mathrm{S}\end{array}$ & $\begin{array}{c}5160 \\
(6810)\end{array}$ & -- & $\begin{array}{c}9420 \\
(8570)\end{array}$ & $\begin{array}{l}10,350 \\
(9950)\end{array}$ & $\begin{array}{c}10,920 \\
(10,220)\end{array}$ & $\begin{array}{c}12,020 \\
-\end{array}$ & $\begin{array}{l}15.9 \\
19.2\end{array}$ \\
\hline $17 \mathrm{~A} \ddagger$ & 4.065 & $\mathrm{H}$ & 0.280 & $\begin{array}{r}73 \\
122\end{array}$ & $\begin{array}{l}\mathrm{S} \\
\mathrm{S}\end{array}$ & $\begin{array}{c}6080 \\
(7180)\end{array}$ & -- & $\begin{array}{c}8570 \\
(9150)\end{array}$ & $\begin{array}{c}9950 \\
(10,437)\end{array}$ & $\begin{array}{c}11,440 \\
(11,390)\end{array}$ & -- & $\begin{array}{l}16.1 \\
14.1\end{array}$ \\
\hline $20 \ddagger \ddagger$ & 4.782 & $\mathrm{H}$ & 0.275 & $\begin{array}{r}73 \\
122 \\
73 \\
122\end{array}$ & $\begin{array}{l}\text { S } \\
\text { S } \\
\text { I } \\
\text { I }\end{array}$ & $\begin{array}{c}6540 \\
(8000) \\
6960 \\
(7570)\end{array}$ & $\begin{array}{c}8070 \\
(9240) \\
8090 \\
(8450)\end{array}$ & $\begin{array}{c}9662 \\
(10,020) \\
10,310 \\
(10,610)\end{array}$ & $\begin{array}{c}9770 \\
(11,250) \\
11,590 \\
(11,8) 0\end{array}$ & $\begin{array}{c}12,250 \\
(11,100) \\
11,590 \\
(11,580)\end{array}$ & $\begin{array}{c}10,840 \\
(11,460) \\
11,300 \\
(11,480)\end{array}$ & $\begin{array}{l}1.1 \\
12.3 \\
12.4 \\
11.3\end{array}$ \\
\hline
\end{tabular}

* Cement content by solid volume.

** Water-reducing admixture: C - conventional, H - high range.

+ Water-cement ratio.

$+\dagger$ Moisture curing condition: S - sealed, I - immersed.

¥Values are average strength of three cylinders, one each from three batches.

\# RC-822(2) cement used; al1 other mixtures used RC-822(1).

$\S$ Represents strength gain between 28 days and 1 year with respect to 28 -day strength. 
Table 10

Compressive Strength Versus Age for Concrete Mixtures with 20 Percent Fly Ash

Replacement in Order of Decreasing Water-Cementitious Materials Ratio

\begin{tabular}{|c|c|c|c|c|c|c|c|c|c|c|c|c|}
\hline \multirow[b]{2}{*}{$\begin{array}{c}\text { Mixture } \\
\text { No. }\end{array}$} & \multirow{2}{*}{$\begin{array}{l}\text { Cement* } \\
\text { Content } \\
\mathrm{ft}^{3} / \mathrm{yd}^{3} \\
\end{array}$} & \multirow[b]{2}{*}{ WRA** } & \multirow[b]{2}{*}{$\begin{array}{l}\text { W/Ct } \\
\text { By Wt }\end{array}$} & \multicolumn{2}{|c|}{ Curing Conditiontt } & \multirow{2}{*}{\multicolumn{6}{|c|}{ Compressive Strength, psi $\ddagger$}} & \multirow{2}{*}{$\begin{array}{c}\text { Strength }+t \\
\text { Gain After } \\
28 \text { Days } \\
\text { Percent } \\
\end{array}$} \\
\hline & & & & $\frac{\text { Temp. }}{\mathrm{O}^{\mathrm{O}} \mathrm{F}}$ & Moisture & & & & & & & \\
\hline 2 & 3.347 & -- & 0.508 & $\begin{array}{r}73 \\
122\end{array}$ & $\begin{array}{l}\mathrm{S} \\
\mathrm{S}\end{array}$ & $\begin{array}{c}2370 \\
(3310)\end{array}$ & -- & $\begin{array}{c}5300 \\
(5840)\end{array}$ & $\begin{array}{c}6730 \\
(6140)\end{array}$ & $\begin{array}{c}7860 \\
(6100)\end{array}$ & 8030 & $\begin{array}{r}48.3 \\
4.4\end{array}$ \\
\hline 6 & 3.347 & C & 0.457 & $\begin{array}{r}73 \\
122\end{array}$ & $\begin{array}{l}S \\
S\end{array}$ & $\begin{array}{c}2420 \\
(3470)\end{array}$ & -- & $\begin{array}{c}5680 \\
(6200)\end{array}$ & $\begin{array}{c}7040 \\
(6450)\end{array}$ & $\begin{array}{c}8350 \\
(6730)\end{array}$ & $\begin{array}{c}8760 \\
--\end{array}$ & $\begin{array}{r}47.0 \\
8.5\end{array}$ \\
\hline 14 & 3.347 & $\mathrm{H}$ & 0.385 & $\begin{array}{r}73 \\
122\end{array}$ & $\begin{array}{l}S \\
S\end{array}$ & $\begin{array}{c}3550 \\
(4940)\end{array}$ & -- & $\begin{array}{c}6790 \\
(8160)\end{array}$ & $\begin{array}{c}8820 \\
(8100)\end{array}$ & $\begin{array}{l}10,220 \\
(8410)\end{array}$ & $\begin{array}{c}9920 \\
--\end{array}$ & $\begin{array}{r}50.5 \\
3.1\end{array}$ \\
\hline
\end{tabular}

\footnotetext{
* Cementitious material content by volume.

** Water-reducing admixture: C - conventional, H - high range.

+ Water-cementitious materials ratio.

$+\dagger$ Moisture curing condition: S - sealed, I - immersed.

$\ddagger$ Values represent average strength of three cylinders, one each from three batches.

$\ddagger$ Represents strength gain between 28 days and 1 year with respect to 28 -day strength.
} 
Table 11

Compressive Strength Versus Age for Concrete Mixture with 35 Percent Fly Ash

Replacement in Order of Decreasing Water-Cementitious Materials Ratio

\begin{tabular}{|c|c|c|c|c|c|c|c|c|c|c|c|c|}
\hline $\begin{array}{l}\text { Mixture } \\
\text { No. } \\
\end{array}$ & $\begin{array}{l}\text { Cement* } \\
\text { Content } \\
\mathrm{ft} / \mathrm{yd}^{3} \\
\end{array}$ & WRA** & $\begin{array}{l}\text { W/Ct } \\
\text { By Wt }\end{array}$ & $\frac{\frac{\text { Curing }}{\text { Temp. }}}{\frac{\mathrm{o}_{\mathrm{F}}}{}}$ & $\begin{array}{r}\text { Conditiontt } \\
\text { Moisture }\end{array}$ & 3 day & $\begin{array}{l}\text { Comp } \\
7 \text { day }\end{array}$ & $\frac{\text { ressive }}{28 \text { day }}$ & $\begin{array}{l}\text { Strengtl } \\
90 \text { day }\end{array}$ & $\begin{array}{l}\text { psi } \\
1 \text { year }\end{array}$ & 2 year & $\begin{array}{r}\text { Strength } t \\
\text { Gain After } \\
28 \text { Days } \\
\text { Percent } \\
\end{array}$ \\
\hline 25 & 2.630 & C & 0.548 & $\begin{array}{r}73 \\
122\end{array}$ & $\begin{array}{l}S \\
S\end{array}$ & $\begin{array}{c}1230 \\
(2110)\end{array}$ & -- & $\begin{array}{c}3760 \\
(5120)\end{array}$ & $\begin{array}{c}5540 \\
(5400)\end{array}$ & $\begin{array}{c}7030 \\
(5380)\end{array}$ & -- & $\begin{array}{r}86.9 \\
5.1\end{array}$ \\
\hline 3 & 3. 347 & -- & 0.529 & $\begin{array}{r}73 \\
122\end{array}$ & $\begin{array}{l}S \\
S\end{array}$ & $\begin{array}{c}1540 \\
(2490)\end{array}$ & -- & $\begin{array}{c}4260 \\
(5380)\end{array}$ & $\begin{array}{c}6400 \\
(5390)\end{array}$ & $\begin{array}{c}7540 \\
(5420)\end{array}$ & $\begin{array}{l}-- \\
--\end{array}$ & $\begin{array}{r}77.0 \\
0.7\end{array}$ \\
\hline $27 \mathrm{~A}$ & 2.630 & $\mathrm{H}$ & 0.508 & 73 & $\mathrm{~S}$ & -- & -- & 3580 & 5520 & - & -- & -- \\
\hline 27 & 2.630 & $\mathrm{H}$ & 0.482 & $\begin{array}{r}73 \\
122\end{array}$ & $\begin{array}{l}S \\
S\end{array}$ & $\begin{array}{c}1510 \\
(2360)\end{array}$ & -- & $\begin{array}{c}4050 \\
(4990)\end{array}$ & $\begin{array}{c}5720 \\
(5050)\end{array}$ & $\begin{array}{c}7070 \\
(5180)\end{array}$ & - & $\begin{array}{r}74.6 \\
3.8\end{array}$ \\
\hline 7 & 3.347 & C & 0.472 & $\begin{array}{r}73 \\
122 \\
73 \\
122\end{array}$ & $\begin{array}{l}\text { S } \\
\text { S } \\
\text { I } \\
\text { I }\end{array}$ & $\begin{array}{c}1840 \\
(2720) \\
1860 \\
(2740)\end{array}$ & $\begin{array}{c}3160 \\
(4840) \\
3250 \\
(4460\end{array}$ & $\begin{array}{c}5040 \\
(5970) \\
5260 \\
(6580)\end{array}$ & $\begin{array}{c}7480 \\
(6580) \\
7460 \\
(7140)\end{array}$ & $\begin{array}{c}8520 \\
(6510) \\
8670 \\
(7000)\end{array}$ & $\begin{array}{c}9010 \\
(6720) \\
8850 \\
(7820)\end{array}$ & $\begin{array}{r}69.0 \\
9.0 \\
64.8 \\
6.4\end{array}$ \\
\hline $11 \ddagger \ddagger$ & 3.347 & C & 0.467 & $\begin{array}{r}73 \\
122\end{array}$ & $\begin{array}{l}\mathrm{S} \\
\mathrm{S}\end{array}$ & $\begin{array}{c}1980 \\
(3290)\end{array}$ & -- & $\begin{array}{c}5050 \\
(6220)\end{array}$ & $\begin{array}{c}6470 \\
(6260)\end{array}$ & $\begin{array}{c}8220 \\
(6420)\end{array}$ & $\overline{--}$ & $\begin{array}{r}62.8 \\
3.2\end{array}$ \\
\hline $7 \mathrm{~A}$ & 3.347 & C & 0.440 & $\begin{array}{r}73 \\
122\end{array}$ & $\begin{array}{l}\mathrm{S} \\
\mathrm{S}\end{array}$ & $\begin{array}{c}1950 \\
(3130)\end{array}$ & -- & $\begin{array}{l}(5050) \\
(6100)\end{array}$ & $\begin{array}{c}6990 \\
(6370)\end{array}$ & $\begin{array}{c}8320 \\
(6420)\end{array}$ & -- & $\begin{array}{r}64.8 \\
5.2\end{array}$ \\
\hline 15 & 3.347 & $\mathrm{H}$ & 0.432 & $\begin{array}{r}73 \\
122 \\
73 \\
122\end{array}$ & $\begin{array}{l}\text { S } \\
\text { S } \\
\text { I } \\
\text { I }\end{array}$ & $\begin{array}{c}2340 \\
(3540) \\
2340 \\
(3390)\end{array}$ & $\begin{array}{c}3570 \\
(5720) \\
3730 \\
(5590)\end{array}$ & $\begin{array}{c}5730 \\
(6690) \\
6160 \\
(7350)\end{array}$ & $\begin{array}{c}7620 \\
(6600) \\
8510 \\
(7540)\end{array}$ & $\begin{array}{c}8470 \\
(6540) \\
9930 \\
(7620)\end{array}$ & $\begin{array}{c}8630 \\
(6510) \\
9590 \\
(7800)\end{array}$ & $\begin{array}{r}47.8 \\
-2.2 \\
61.2 \\
3.7\end{array}$ \\
\hline $12 \ddagger \ddagger$ & 4.065 & C & 0.397 & $\begin{array}{r}73 \\
122\end{array}$ & $\begin{array}{l}\mathrm{S} \\
\mathrm{S}\end{array}$ & $\begin{array}{c}2620 \\
(4020)\end{array}$ & -- & $\begin{array}{c}6060 \\
(7350)\end{array}$ & $\begin{array}{c}8030 \\
(7580)\end{array}$ & $\begin{array}{c}9880 \\
(7690)\end{array}$ & -- & $\begin{array}{r}63.0 \\
4.6\end{array}$ \\
\hline 9 & 4.065 & C & 0.372 & $\begin{array}{r}73 \\
122\end{array}$ & $\begin{array}{l}\mathrm{S} \\
\mathrm{S}\end{array}$ & $\begin{array}{c}3000 \\
(4470)\end{array}$ & -- & $\begin{array}{c}7340 \\
(7800)\end{array}$ & $\begin{array}{c}8520 \\
(7910)\end{array}$ & $\begin{array}{c}9620 \\
(7910)\end{array}$ & -- & $\begin{array}{r}31.1 \\
1.4\end{array}$ \\
\hline
\end{tabular}


Table 11 (Concluded)

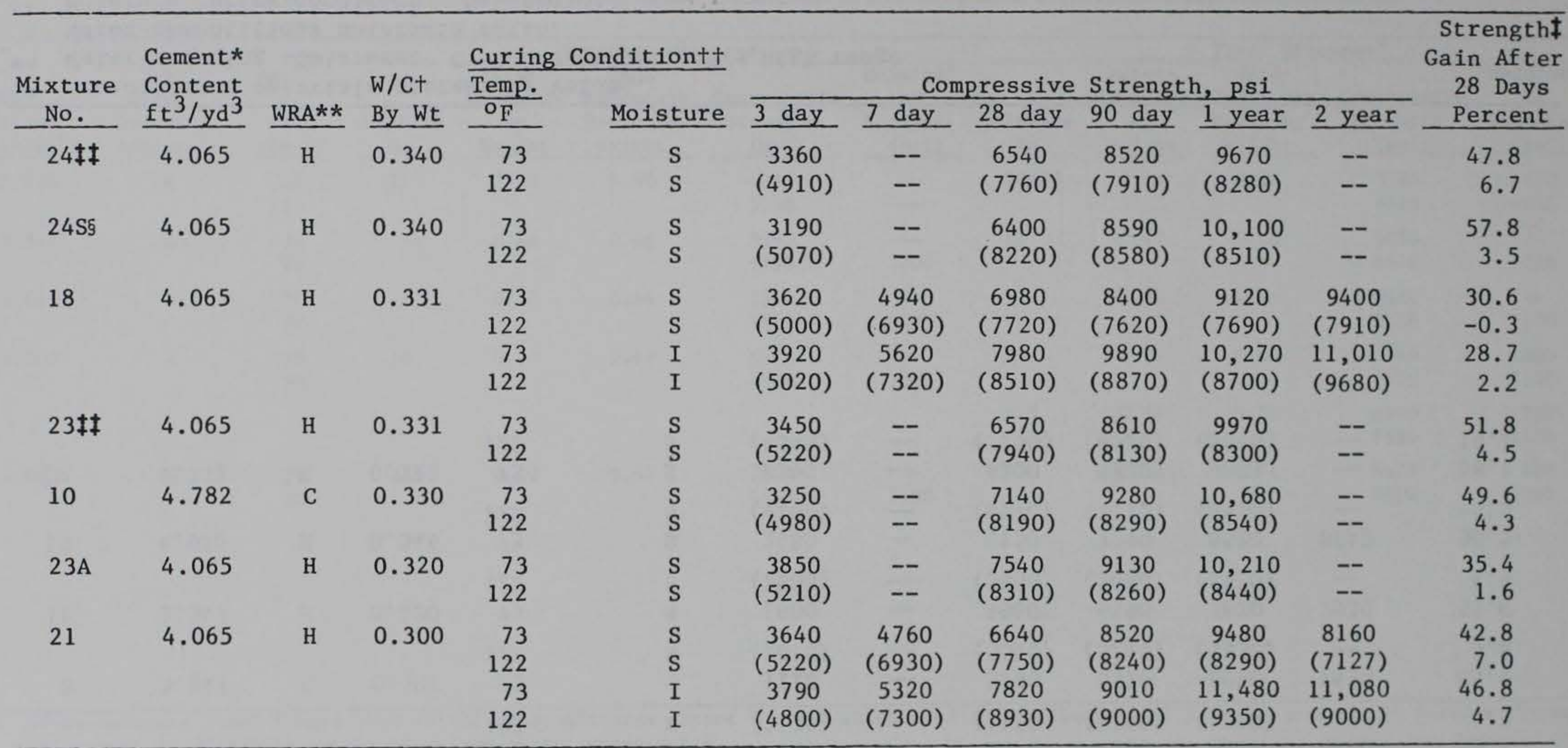

\footnotetext{
* Cementitious material content by volume.

** Water-reducing admixture: C - conventional, H - high range.

+ Water-cementitious materials ratio.

+† Moisture curing condition: S - sealed, I - immersed.

$\ddagger$ Represents strength gain between 28 days and 1 year with respect to 28 -day strength.

It 50 -mm fibers used.

§ $30-\mathrm{mm}$ fibers used.
} 
Table 12

Compressive Strength Versus Age for Concrete Mixtures with 50 Percent Fly Ash

Replacement in Order of Increasing Water-Cementitious Materials Ratio

\begin{tabular}{|c|c|c|c|c|c|c|c|c|c|c|c|c|}
\hline $\begin{array}{c}\text { Mixture } \\
\text { No. } \\
\end{array}$ & $\begin{array}{l}\text { Cement* } \\
\text { Content } \\
\mathrm{ft}^{3} / \mathrm{yd}^{3} \\
\end{array}$ & WRA** & $\begin{array}{l}\text { W/CT } \\
\text { By Wt }\end{array}$ & $\frac{\frac{\text { Curing }}{\text { Temp. }}}{\frac{\mathrm{o}_{\mathrm{F}}}{}}$ & $\begin{array}{l}\text { nditiontt } \\
\text { Moisture }\end{array}$ & 3 day & $\begin{aligned} \text { Co } \\
7 \text { day }\end{aligned}$ & $\frac{\text { pressive }}{28 \text { day }}$ & $\begin{array}{l}\text { Strengt } \\
90 \text { day }\end{array}$ & $\frac{h, \text { psi }}{1 \text { year }}$ & 2 year & $\begin{array}{r}\text { Strength } \\
\text { Gain After } \\
28 \text { Days } \\
\text { Percent }\end{array}$ \\
\hline 4 & 3.347 & -- & 0.554 & $\begin{array}{r}73 \\
122\end{array}$ & $\begin{array}{l}\mathrm{S} \\
\mathrm{S}\end{array}$ & $\begin{array}{c}960 \\
(1730)\end{array}$ & -- & $\begin{array}{c}3070 \\
(4160)\end{array}$ & $\begin{array}{c}4600 \\
(4260)\end{array}$ & $\begin{array}{c}5810 \\
(4380)\end{array}$ & $\begin{array}{c}6440 \\
--\end{array}$ & $\begin{array}{r}89.2 \\
5.3\end{array}$ \\
\hline 8 & 3.347 & C & 0.507 & $\begin{array}{r}73 \\
122\end{array}$ & $\begin{array}{l}\mathrm{S} \\
\mathrm{S}\end{array}$ & $\begin{array}{c}1110 \\
(2010)\end{array}$ & -- & $\begin{array}{c}3780 \\
(5040)\end{array}$ & $\begin{array}{c}5520 \\
(5240)\end{array}$ & $\begin{array}{c}6950 \\
(5330)\end{array}$ & $\begin{array}{c}7630 \\
--\end{array}$ & $\begin{array}{r}83.9 \\
5.8\end{array}$ \\
\hline 16 & 3.347 & H & 0.420 & $\begin{array}{r}73 \\
122\end{array}$ & $\begin{array}{l}\mathrm{S} \\
\mathrm{S}\end{array}$ & $\begin{array}{c}1600 \\
(2800)\end{array}$ & -- & $\begin{array}{c}4960 \\
(5680)\end{array}$ & $\begin{array}{c}6590 \\
(5680)\end{array}$ & $\begin{array}{c}7620 \\
(5920)\end{array}$ & $\begin{array}{c}7930 \\
--\end{array}$ & $\begin{array}{r}53.6 \\
4.9\end{array}$ \\
\hline 19 & 4.065 & $\mathrm{H}$ & 0.346 & $\begin{array}{r}73 \\
122\end{array}$ & $\begin{array}{l}\mathrm{S} \\
\mathrm{S}\end{array}$ & $\begin{array}{c}2480 \\
(4100)\end{array}$ & -- & $\begin{array}{c}6150 \\
(6970)\end{array}$ & $\begin{array}{c}7790 \\
(7170)\end{array}$ & $\begin{array}{c}8520 \\
(6930)\end{array}$ & $\begin{array}{c}8840 \\
--\end{array}$ & $\begin{array}{l}38.5 \\
-0.6\end{array}$ \\
\hline 22 & 4.782 & H & 0.320 & $\begin{array}{r}73 \\
122\end{array}$ & $\begin{array}{l}S \\
S\end{array}$ & $\begin{array}{c}2790 \\
(4840)\end{array}$ & -- & $\begin{array}{c}6200 \\
(7750)\end{array}$ & $\begin{array}{c}8820 \\
(8520)\end{array}$ & $\begin{array}{c}9803 \\
(8840)\end{array}$ & -- & $\begin{array}{l}58.1 \\
14.1\end{array}$ \\
\hline
\end{tabular}

* Cementitious materials content by volume.

** Water-reducing admixture: C - conventional, $\mathrm{H}$ - high range.

$\dagger$ Water-cementitious materials ratio.

$+\dagger$ Moisture curing condition: S - sealed.

$\ddagger$ Represents strength gain between 28 days and age at 1 year with respect to 28-day strength. 
Table 13

Modulus of Rupture and Compressive Strength Comparisons for Nonfiber and Deformed Stee1-Fiber Mixtures

\begin{tabular}{|c|c|c|c|c|c|c|c|c|c|c|c|c|}
\hline \multirow[b]{2}{*}{$\begin{array}{c}\mathrm{CM}^{* *} \\
\text { Volume } \\
\left(\mathrm{ft}^{2} / \mathrm{yd}^{3}\right) \\
\end{array}$} & \multirow[b]{2}{*}{ 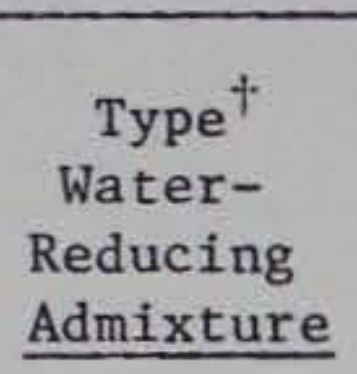 } & \multirow[b]{2}{*}{$\begin{array}{c}\text { Age }^{\dagger+} \\
\text { at } \\
\text { Test } \\
\text { (days) } \\
\end{array}$} & \multicolumn{5}{|c|}{ Nonfiber Mixtures } & \multicolumn{5}{|c|}{ Fiber Mixtures ${ }^{\star}$} \\
\hline & & & $\begin{array}{c}\text { Mixture } \\
\text { No. } \\
\end{array}$ & $\begin{array}{c}\text { Water- } \\
\text { CM Ratio } \\
\text { by } \\
\text { Weight } \\
\end{array}$ & $\begin{array}{c}\text { Sand- } \\
\text { Aggregate } \\
\text { Ratio by } \\
\text { Weight } \\
\end{array}$ & $\begin{array}{c}\text { Compressive } \\
\text { Strength } \\
\text { (psi) } \\
\end{array}$ & $\begin{array}{l}\text { Modulus } f \\
\text { of } \\
\text { Rupture } \\
\text { (psi) } \\
\end{array}$ & $\begin{array}{c}\text { Mixture } \\
\text { No. } \\
\end{array}$ & $\begin{array}{c}\text { Water- } \\
\text { CM Ratio } \\
\text { by } \\
\text { Weight } \\
\end{array}$ & $\begin{array}{c}\text { Sand- } \\
\text { Aggregate } \\
\text { Ratio by } \\
\text { Weight } \\
\end{array}$ & $\begin{array}{l}\text { Compressive } \\
\text { Strength } \\
\text { (psi) }\end{array}$ & $\begin{array}{c}\text { Modulust } \\
\text { of } \\
\text { Rupture } \\
\text { (psi) } \\
\end{array}$ \\
\hline 2.630 & $\mathrm{H}$ & $\begin{array}{l}28 \\
90\end{array}$ & 27 & 0.48 & 0.50 & $\begin{array}{l}4050 \\
5720\end{array}$ & -- & $27 \mathrm{~A} \neq \ddagger$ & 0.51 & 0.54 & $\begin{array}{l}3580 \\
5520\end{array}$ & $\begin{array}{r}670 \\
1045\end{array}$ \\
\hline 3.347 & C & $\begin{array}{l}28 \\
90\end{array}$ & $7 \mathrm{~A}$ & 0.44 & 0.46 & $\begin{array}{l}5050 \\
6990\end{array}$ & $\overline{1000}$ & 11 & 0.47 & 0.49 & $\begin{array}{l}5050 \\
6470\end{array}$ & $\overline{1010}$ \\
\hline 4.065 & C & $\begin{array}{l}28 \\
90\end{array}$ & 9 & 0.37 & 0.44 & $\begin{array}{l}7340 \\
8520\end{array}$ & $-\overline{1095}$ & 12 & 0.40 & 0.48 & $\begin{array}{l}6060 \\
8030\end{array}$ & $\overline{1100}$ \\
\hline \multirow[t]{2}{*}{4.065} & $\mathrm{H}$ & $\begin{array}{l}28 \\
90\end{array}$ & 18 & 0.33 & 0.48 & $\begin{array}{l}6980 \\
8400\end{array}$ & -- & 24 & 0.34 & 0.50 & $\begin{array}{l}6540 \\
8520\end{array}$ & $\begin{array}{l}1000 \\
1130\end{array}$ \\
\hline & & & & & & & & $24 \mathrm{~S}$ & 0.34 & 0.50 & $\begin{array}{l}6400 \\
8590\end{array}$ & $\begin{array}{r}830 \\
1100\end{array}$ \\
\hline 4.065 & $\mathrm{H}$ & $\begin{array}{l}28 \\
90\end{array}$ & $23 \mathrm{~A}$ & 0.32 & 0.47 & $\begin{array}{l}7540 \\
9130\end{array}$ & $\overline{1100}$ & 23 & 0.35 & 0.51 & $\begin{array}{l}6570 \\
8610\end{array}$ & $\begin{array}{r}920 \\
1040\end{array}$ \\
\hline
\end{tabular}

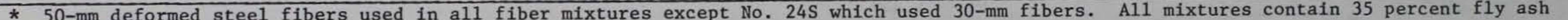
replacement of RC-822(1) cement by volume except where noted.

** Cementitious materials volume. Divide by 0.4782 to obtain volume in $94-1 \mathrm{~b}$ bags

+ Water-reducing admixture: C - conventional, H - high range (superplasticizer).

++ Planned test age was 90 days. Additional tests conducted at 28 days.

$\ddagger$ Values of modulus of rupture represent averages from at least three tests.

$\ddagger$ Cement used is RC-822(2). 
Table 14

Results of Tests to Determine Effect on Compressive

Strength of Replacing Project Cementitious Materials

\begin{tabular}{|c|c|c|c|c|}
\hline \multirow{2}{*}{$\begin{array}{l}\text { Age } \\
\text { days } \\
\end{array}$} & \multirow{2}{*}{$\begin{array}{c}\text { Curing } \\
\text { Temperature } \\
{ }^{\circ} \mathrm{F} \\
\end{array}$} & \multicolumn{3}{|c|}{ Compressive Strength - psi } \\
\hline & & Mixture $15 *$ & Mixture $15 R C * *$ & Mixture $15 \mathrm{RF} \dagger$ \\
\hline 3 & $\begin{array}{r}73 \\
122\end{array}$ & $\begin{array}{l}2340 \\
3540\end{array}$ & $\begin{array}{l}2280 \\
3340\end{array}$ & $\begin{array}{l}2260 \\
3860\end{array}$ \\
\hline 28 & $\begin{array}{r}73 \\
122\end{array}$ & $\begin{array}{l}5730 \\
6690\end{array}$ & $\begin{array}{l}5680 \\
6940\end{array}$ & $\begin{array}{l}6040 \\
7300\end{array}$ \\
\hline 90 & $\begin{array}{r}73 \\
122\end{array}$ & $\begin{array}{l}7620 \\
6660\end{array}$ & $\begin{array}{l}7820 \\
7090\end{array}$ & $\begin{array}{l}8030 \\
7620\end{array}$ \\
\hline 365 & $\begin{array}{r}73 \\
122\end{array}$ & $\begin{array}{l}8470 \\
6540\end{array}$ & $\begin{array}{l}8770 \\
7260\end{array}$ & $\begin{array}{l}9140 \\
7570\end{array}$ \\
\hline
\end{tabular}

* Project cement and fly ash used.

** Cement replaced by Type II with heat of hydration limit from Reference 6 , project fly ash used.

† F1y ash replaced from Reference 6, project cement used. 
Table 15

Concrete Properties* of Mixture 13

\begin{tabular}{|c|c|c|c|c|c|}
\hline $\begin{array}{l}\text { Age } \\
\text { days }\end{array}$ & $\begin{array}{c}\text { Cure } \\
\text { Temperature } \\
{ }_{\mathrm{O}} \mathrm{F} \\
\end{array}$ & $\begin{array}{c}\text { Compressive } \\
\text { Strength } \\
\text { psi } \\
\end{array}$ & $\begin{array}{c}\text { Poisson's } \\
\text { Ratio } \\
\end{array}$ & $\begin{array}{l}\text { Modulus of } \\
\text { Elasticity } \\
\times 10^{6} \text { psi } \\
\end{array}$ & $\begin{array}{c}\text { Modulus of } \\
\text { Rupture } \\
\text { psi } \\
\end{array}$ \\
\hline 1 & $\begin{array}{r}73 \\
122\end{array}$ & $\begin{array}{l}2,540 \\
3,350\end{array}$ & $\begin{array}{l}0.176 \\
0.162\end{array}$ & $\begin{array}{l}3.86 \\
4.11\end{array}$ & $\begin{array}{l}570 \\
630\end{array}$ \\
\hline 3 & $\begin{array}{r}73 \\
122\end{array}$ & $\begin{array}{l}4,560 \\
5,750\end{array}$ & $\begin{array}{l}0.177 \\
0.198\end{array}$ & $\begin{array}{l}4.48 \\
5.34\end{array}$ & $\begin{array}{l}680 \\
860\end{array}$ \\
\hline$=7$ & $\begin{array}{r}73 \\
122\end{array}$ & $\begin{array}{l}6,400 \\
6,910\end{array}$ & $\begin{array}{l}0.182 \\
0.174\end{array}$ & $\begin{array}{l}5.11 \\
5.73\end{array}$ & $\begin{array}{l}870 \\
900\end{array}$ \\
\hline 28 & $\begin{array}{r}73 \\
122\end{array}$ & $\begin{array}{l}8,140 \\
8,780\end{array}$ & $\begin{array}{l}0.192 \\
0.206\end{array}$ & $\begin{array}{l}5.77 \\
6.43\end{array}$ & $\begin{array}{r}900 \\
1005\end{array}$ \\
\hline 90 & $\begin{array}{r}73 \\
122\end{array}$ & $\begin{array}{l}8,910 \\
9,050\end{array}$ & $\begin{array}{l}0.192 \\
0.210\end{array}$ & $\begin{array}{l}6.36 \\
6.68\end{array}$ & $\begin{array}{r}920 \\
1115\end{array}$ \\
\hline 365 & $\begin{array}{r}73 \\
122\end{array}$ & $\begin{array}{l}10,580 \\
10,120\end{array}$ & $\begin{array}{l}0.206 \\
0.210\end{array}$ & $\begin{array}{l}6.53 \\
6.58\end{array}$ & $\begin{array}{l}1040 \\
1140\end{array}$ \\
\hline
\end{tabular}

* Values represent an average of two tests per curing condition. 
Table 16

Strain Capacity Test* Results of Mixture 13

\begin{tabular}{|c|c|c|c|c|}
\hline \multirow{3}{*}{$\begin{array}{l}\text { Age } \\
\text { days }\end{array}$} & \multirow{3}{*}{$\begin{array}{c}\text { Cure } \\
\text { Temperature } \\
\mathrm{O}_{\mathrm{F}} \\
\end{array}$} & \multirow{3}{*}{$\begin{array}{c}\text { Stress** } \\
\text { Capacity } \\
\text { psi } \\
\end{array}$} & \multicolumn{2}{|c|}{ Strain Capacity $\dagger$} \\
\hline & & & Compression & Tęnsion \\
\hline & & & $x 10^{-6} \mathrm{in} . / \mathrm{in}$. & $\times 10^{-6} \mathrm{in} . / \mathrm{in}$. \\
\hline \multirow[t]{2}{*}{1} & 73 & 515 & 105 & 104 \\
\hline & 122 & 570 & 104 & 114 \\
\hline \multirow[t]{2}{*}{3} & 73 & 615 & 120 & 121 \\
\hline & 122 & 770 & 80 & 112 \\
\hline \multirow[t]{2}{*}{7} & 73 & 780 & 140 & 145 \\
\hline & 122 & 810 & 116 & 123 \\
\hline \multirow[t]{2}{*}{28} & 73 & 810 & 117 & 134 \\
\hline & 122 & 905 & 142 & 138 \\
\hline \multirow[t]{2}{*}{90} & 73 & 825 & 127 & 126 \\
\hline & 122 & 1005 & 96 & 153 \\
\hline \multirow[t]{2}{*}{365} & 73 & 940 & 135 & 138 \\
\hline & 122 & 1030 & 123 & 148 \\
\hline
\end{tabular}

* Tests conducted at rapid loading rate ( $40 \mathrm{psi} / \mathrm{min})$.

** Determined at 90 percent of ultimate load ( $0.9 \mathrm{x}$ modulus of rupture).

+ Outside fiber strain at 90 percent of ultimate load. 
Table 17

Adiabatic Temperature Rise

of Mixture 13

Placement Temperature $=58.4 \mathrm{~F}$

\begin{tabular}{cc}
\hline $\begin{array}{c}\text { Age } \\
\text { (days) }\end{array}$ & $\begin{array}{c}\text { Temperature Rise } \\
(\mathrm{F})\end{array}$ \\
\cline { 2 - 2 } 0.00 & 0.0 \\
0.27 & 6.86 \\
0.44 & 17.36 \\
0.61 & 30.42 \\
0.94 & 44.26 \\
1.02 & 46.82 \\
1.23 & 53.89 \\
1.27 & 54.98 \\
1.94 & 66.73 \\
2.27 & 70.34 \\
2.98 & 74.55 \\
3.40 & 76.04 \\
3.95 & 77.00 \\
4.27 & 77.02 \\
4.94 & 78.3 \\
5.27 & 78.59 \\
5.94 & 79.20 \\
6.94 & 79.94 \\
7.94 & 80.38 \\
10.94 & 81.19 \\
12.94 & 81.36 \\
13.94 & 81.37 \\
14.94 & 81.42 \\
20.94 & 81.62 \\
28.00 & 81.80 \\
\hline
\end{tabular}




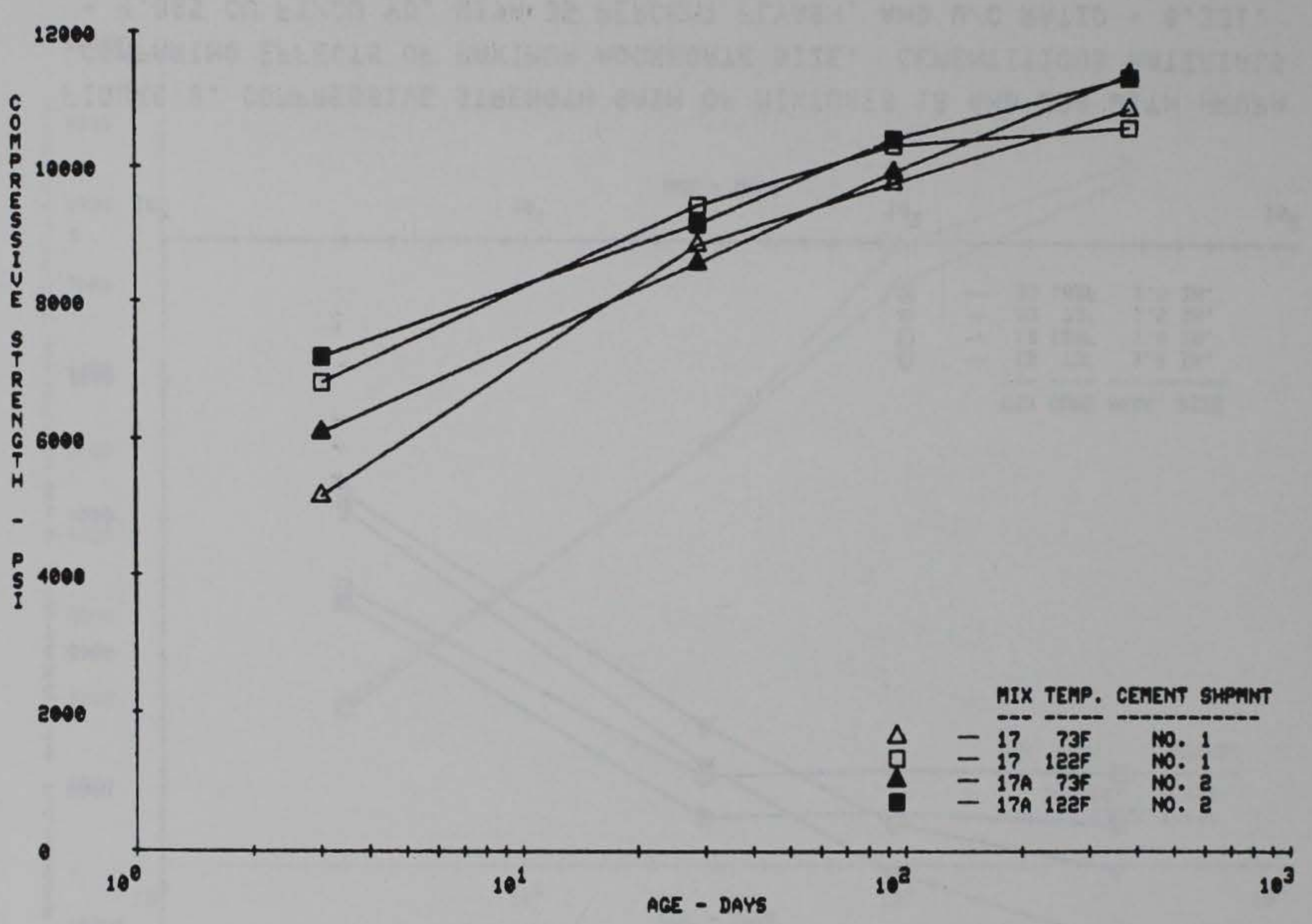

FIGURE 1. COMPRESSIUE STRENGTH GAIN OF MIXTURES 17 AND $17 \mathrm{~A}$ AS A FUNCTION OF DIFFERENT SHIPMENTS OF CEMENT. HRWRA IS USED. 


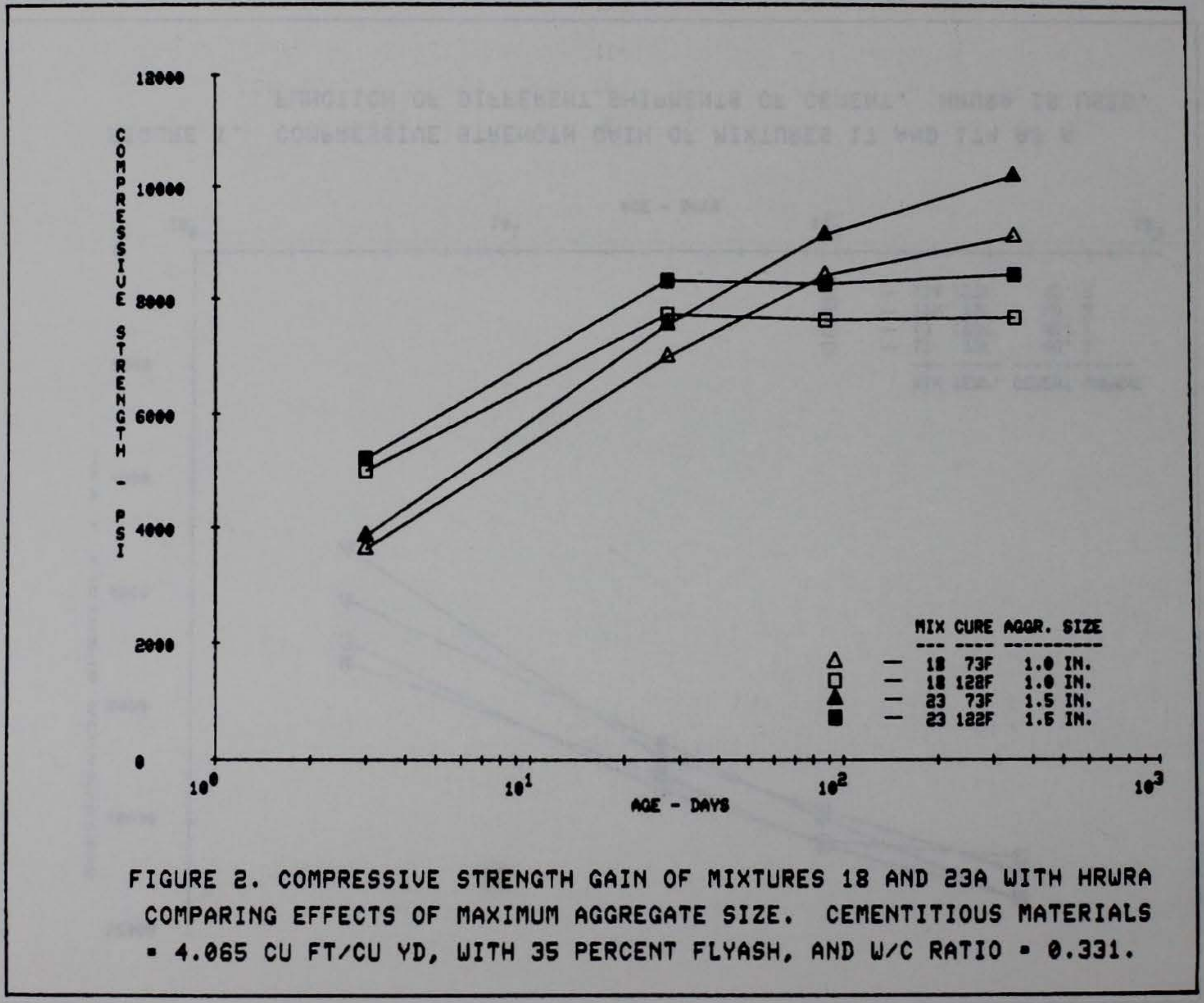




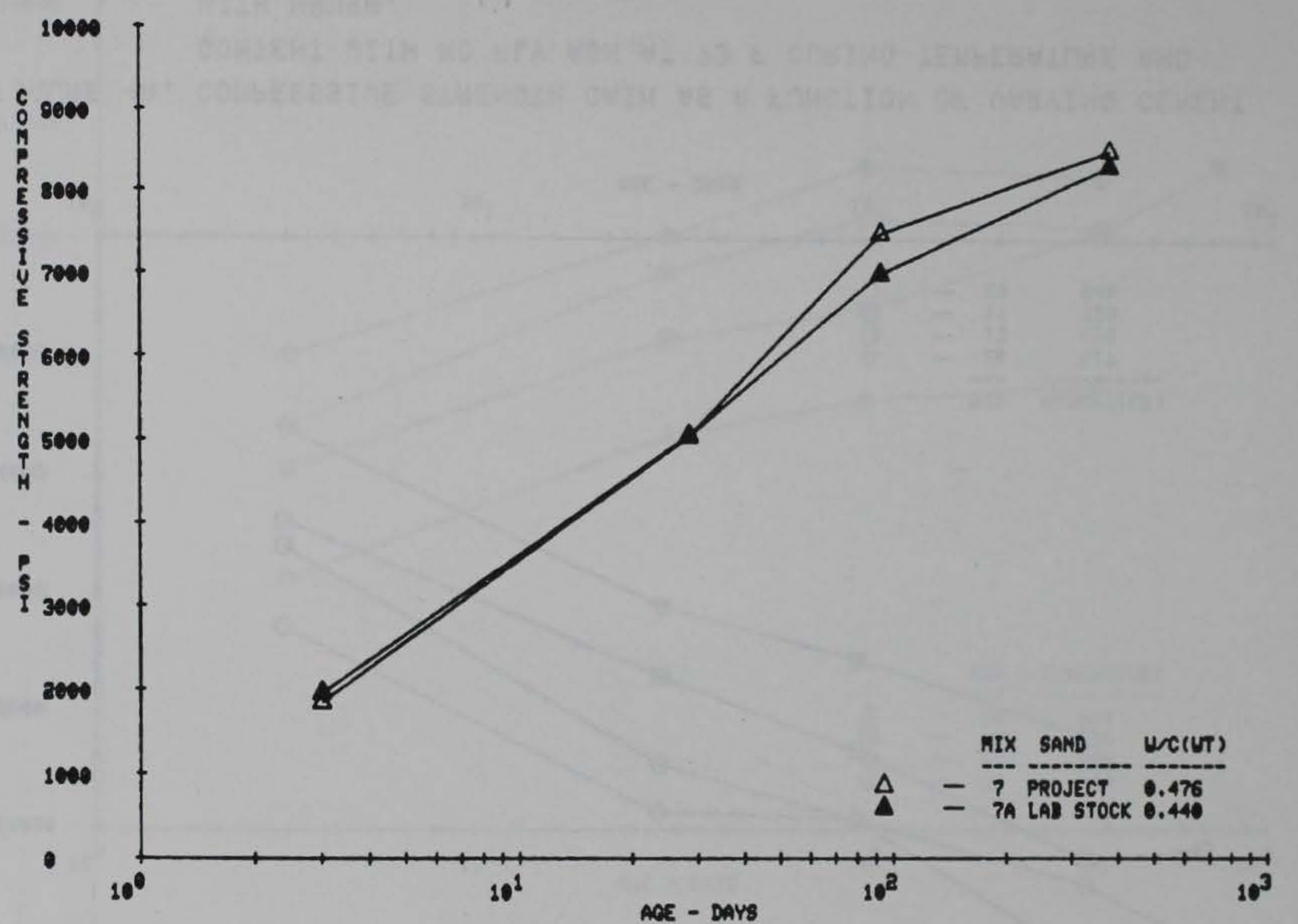

FIGURE 3. COMPRESSIUE STRENGTH GAIN AS A FUNCTION OF SAND USED IN CONCRETE MIXTURES ? AND TA. CURING TEMPERATURE IS T3F UITH CWRA. CEMENTITIOUS MATERIALS CONTENT $\cdot 3.347$ CU FT/CU YD. 


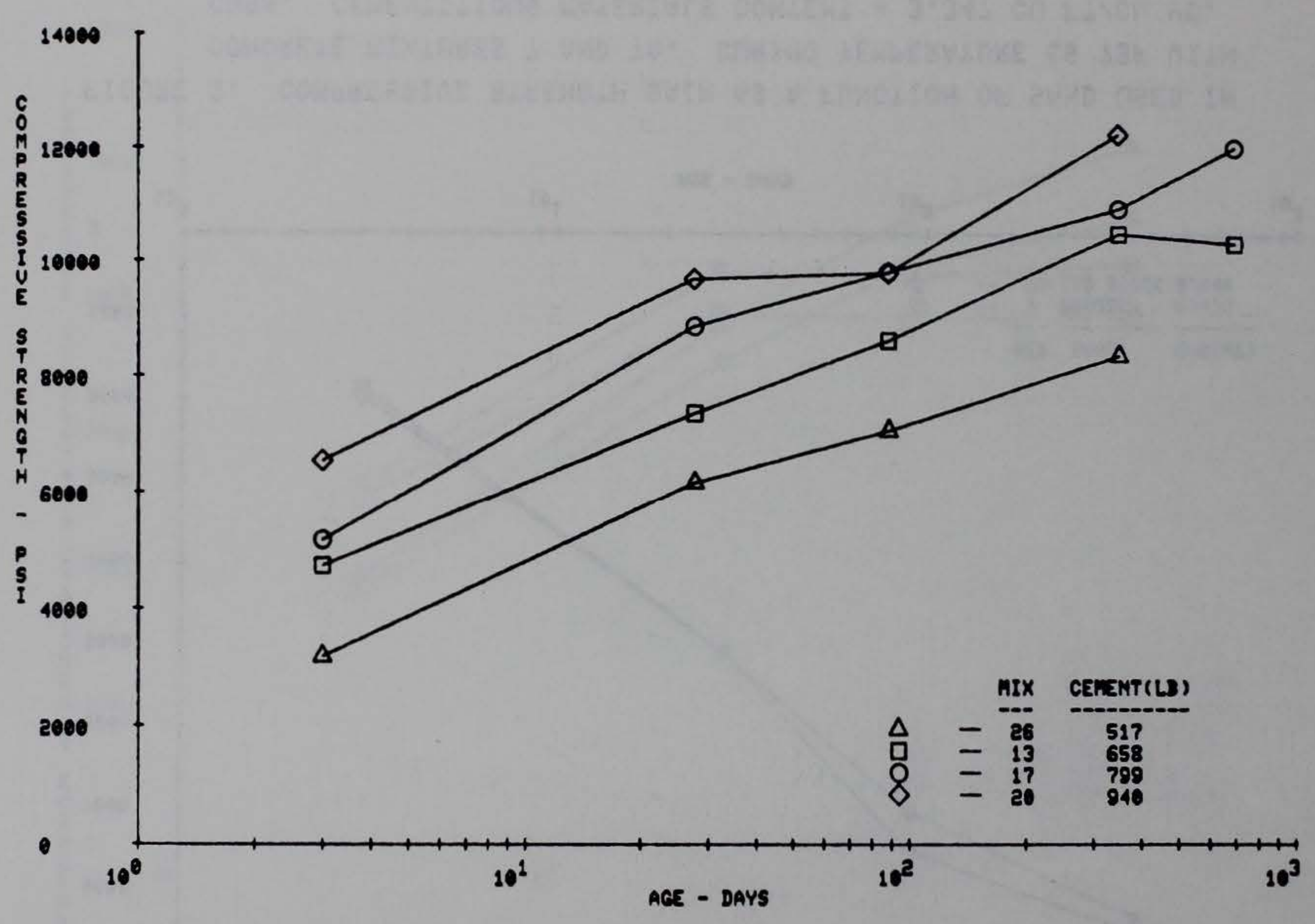

FIGURE 4A. COMPRESSIUE STRENGTH GAIN AS A FUNCTION OF UARYING CEMENT CONTENT WITH NO FLY ASH AT 73 F CURING TEMPERATURE AND WITH HRWRA. 


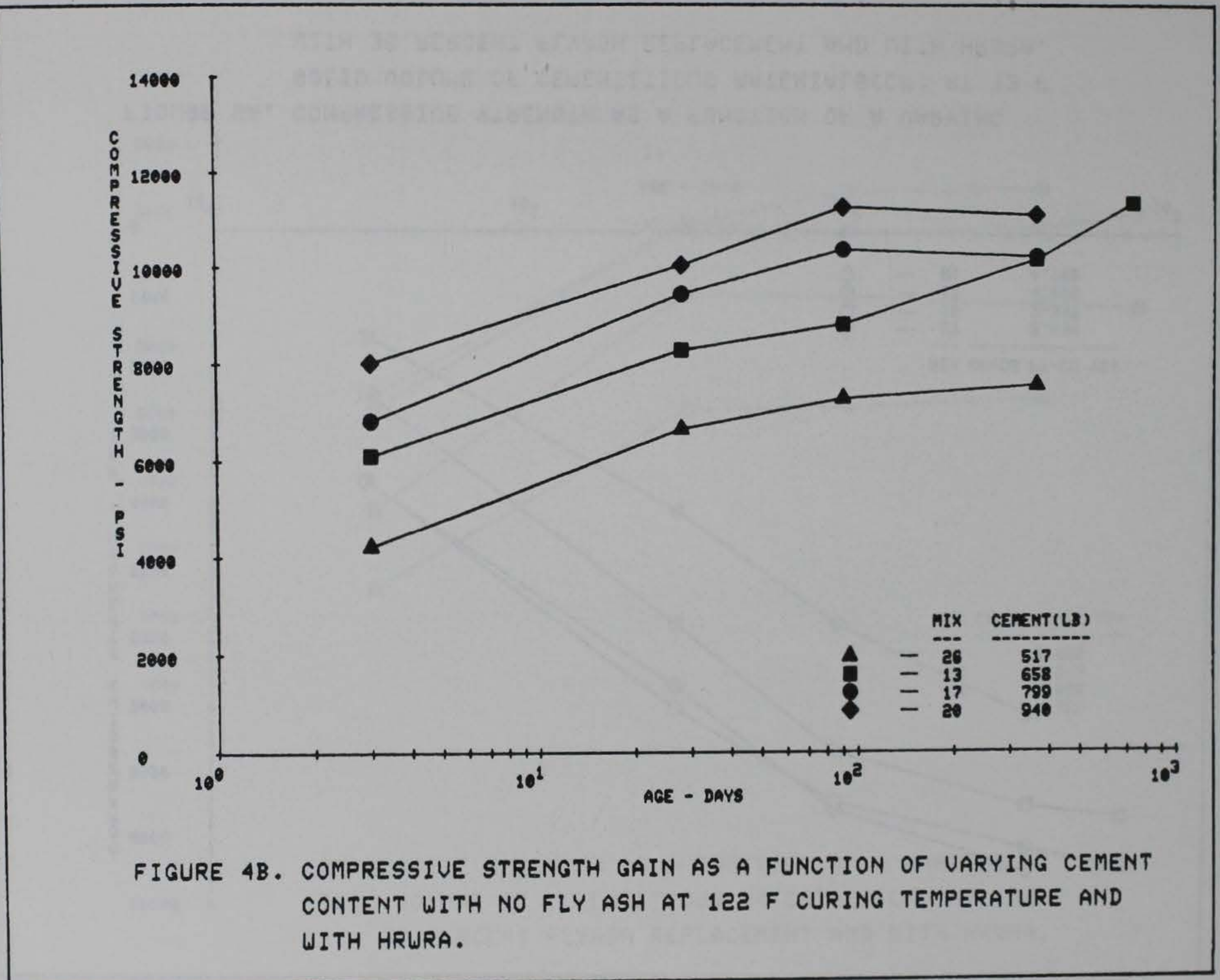




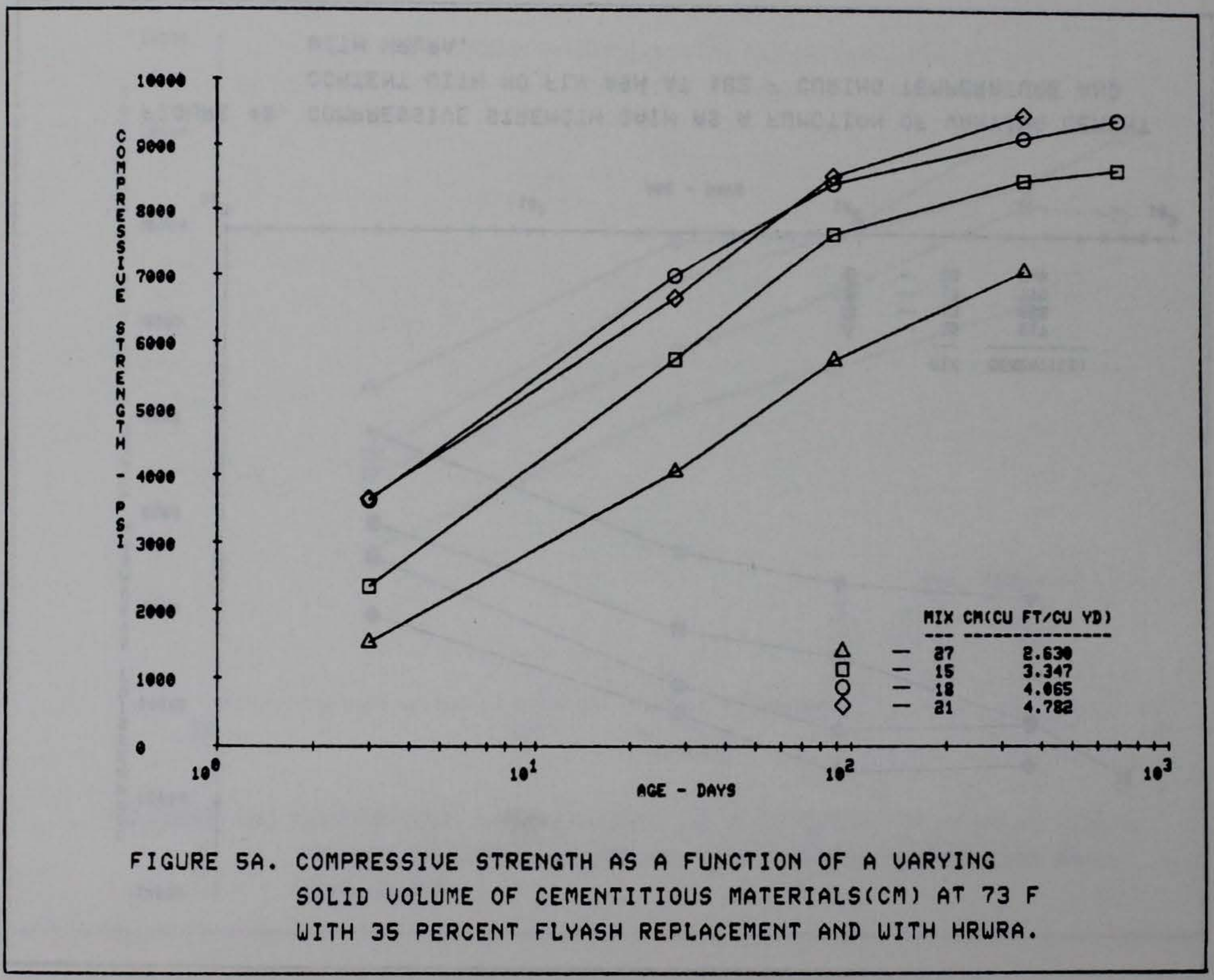




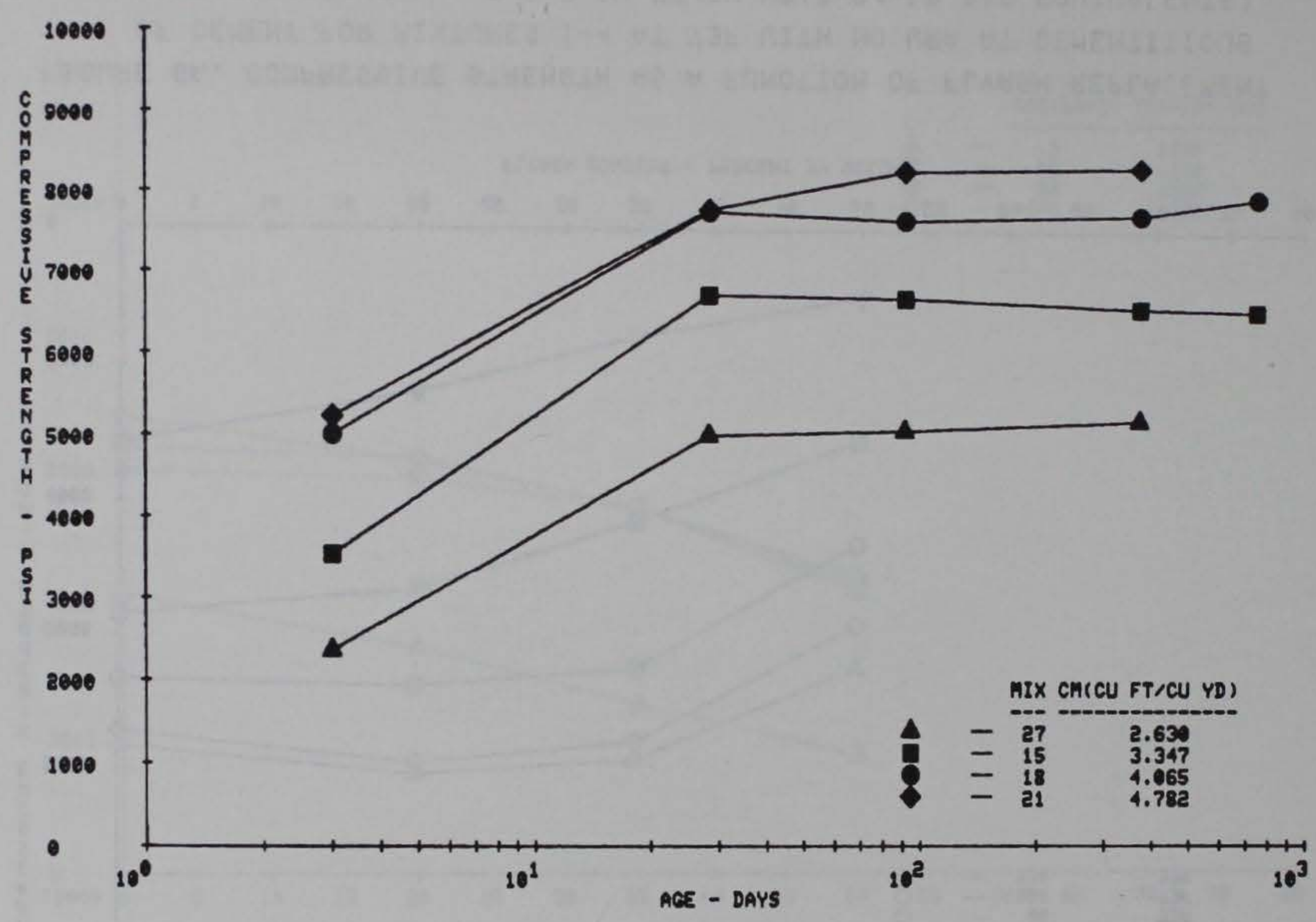

FIGURE 5B. COMPRESSIUE STRENGTH AS A FUNCTION OF A UARYING SOLID VOLUME OF CEMENTITIOUS MATERIALS(CM) AT $122 F$ WITH 35 PERCENT FLYASH REPLACEMENT AND WITH HRWRA. 


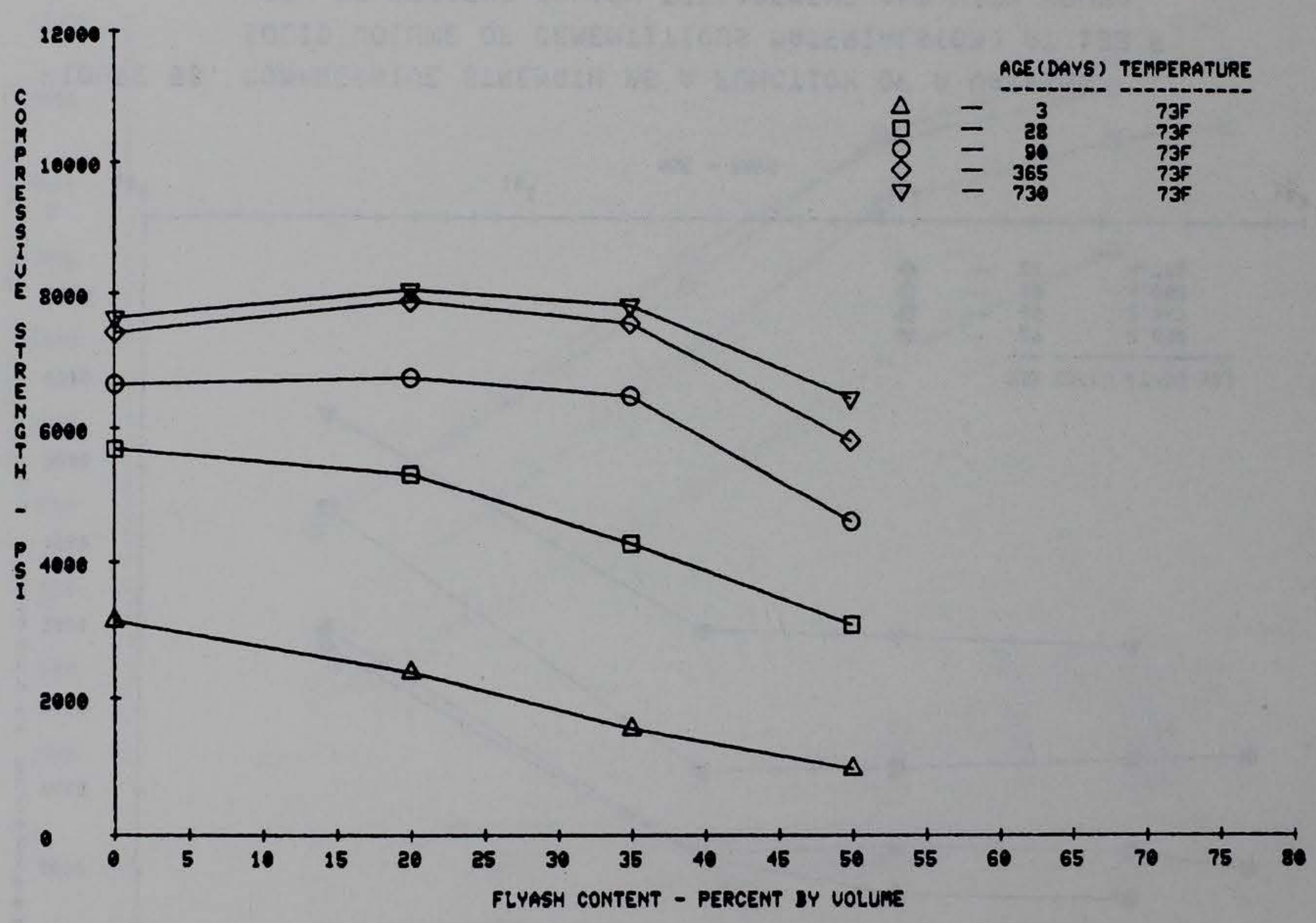

FIGURE 6A. COMPRESSIUE STRENGTH AS A FUNCTION OF FLYASH REPLACEMENT OF CEMENT FOR MIXTURES 1-4 AT T3F WITH NO WRA AT CEMENTITIOUS MATERIAL VOLUMES - 3.347 CU FT/CU YD(7-94-LB BAG EQUIUALENTS). 


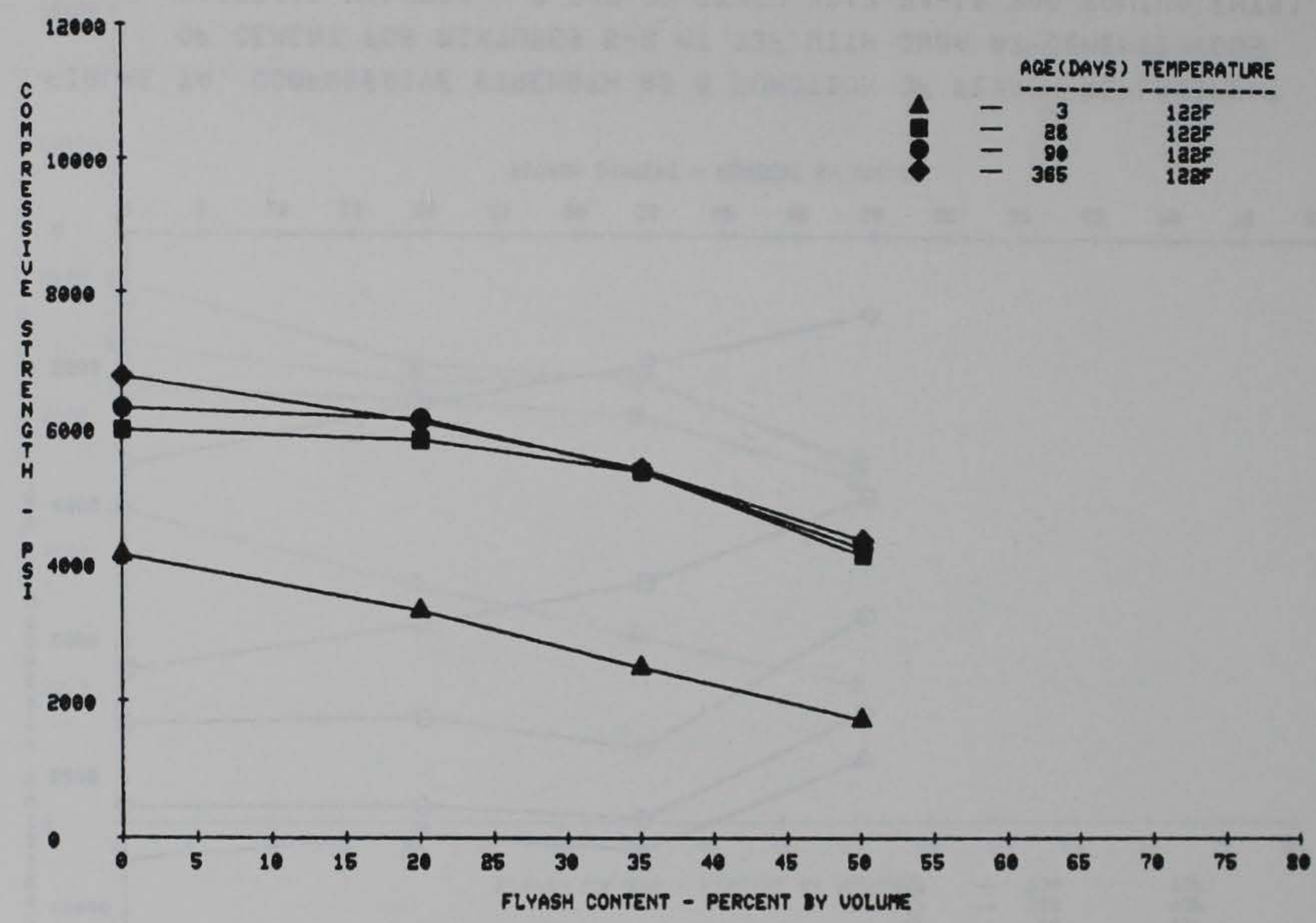

FIGURE 6B. COMPRESSIUE STRENGTH AS A FUNCTION OF FLYASH REPLACEMENT OF CEMENT FOR MIXTURES 1-4 AT $122 F$ WITH NO WRA AT CEMENTITIOUS MATERIAL VOLUMES - 3.347 CU FT/CU YD(7-94-LB BAG EOUIUALENTS). 


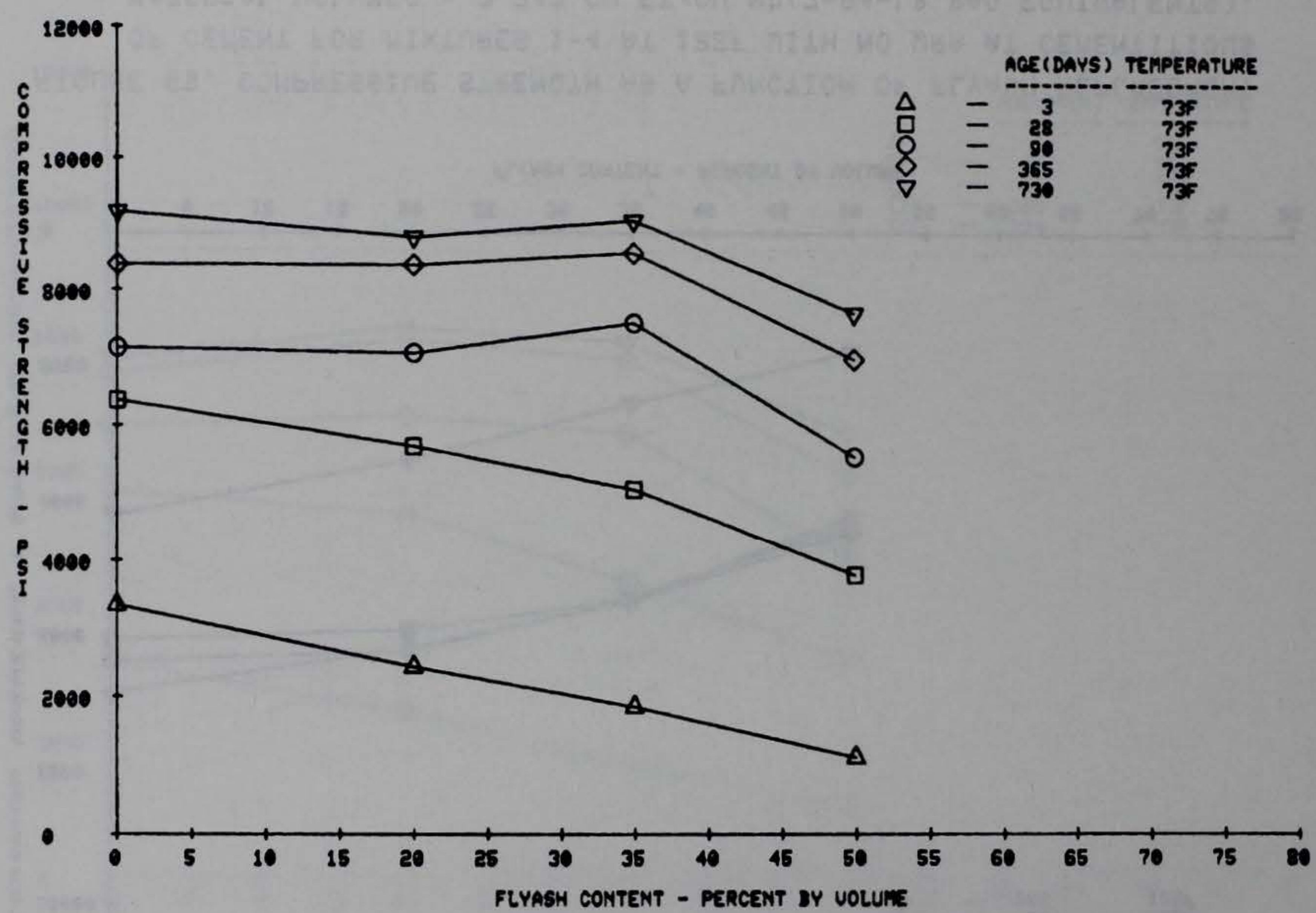

FIGURE 7A. COMPRESSIUE STRENGTH AS A FUNCTION OF FLYASH REPLACEMENT OF CEMENT FOR MIXTURES 5-8 AT T3F WITH CURA AT CEMENTITIOUS MATERIAL VOLUMES - 3.347 CU FT/CU YD(7-94-LB BAG EOUIUALENTS). 


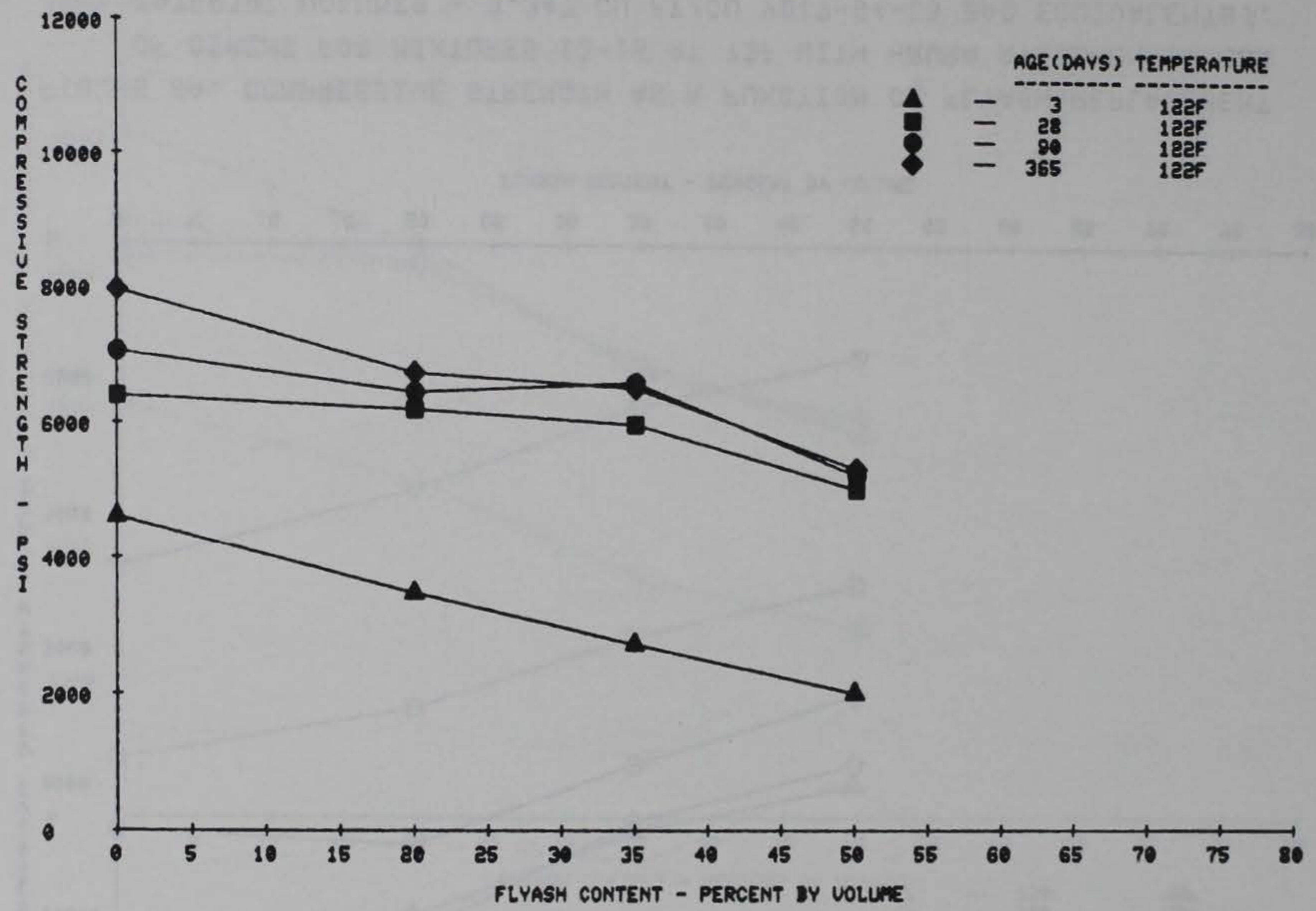

FIGURE 7B. COMPRESSIUE STRENGTH AS A FUNCTION OF FLYASH REPLACEMENT OF CEMENT FOR MIXTURES 5-8 AT $122 F$ WITH CWRA AT CEMENTITIOUS MATERIAL VOLUMES - 3.347 CU FT/CU YD(7-94-LB BAG EQUIUALENTS). 


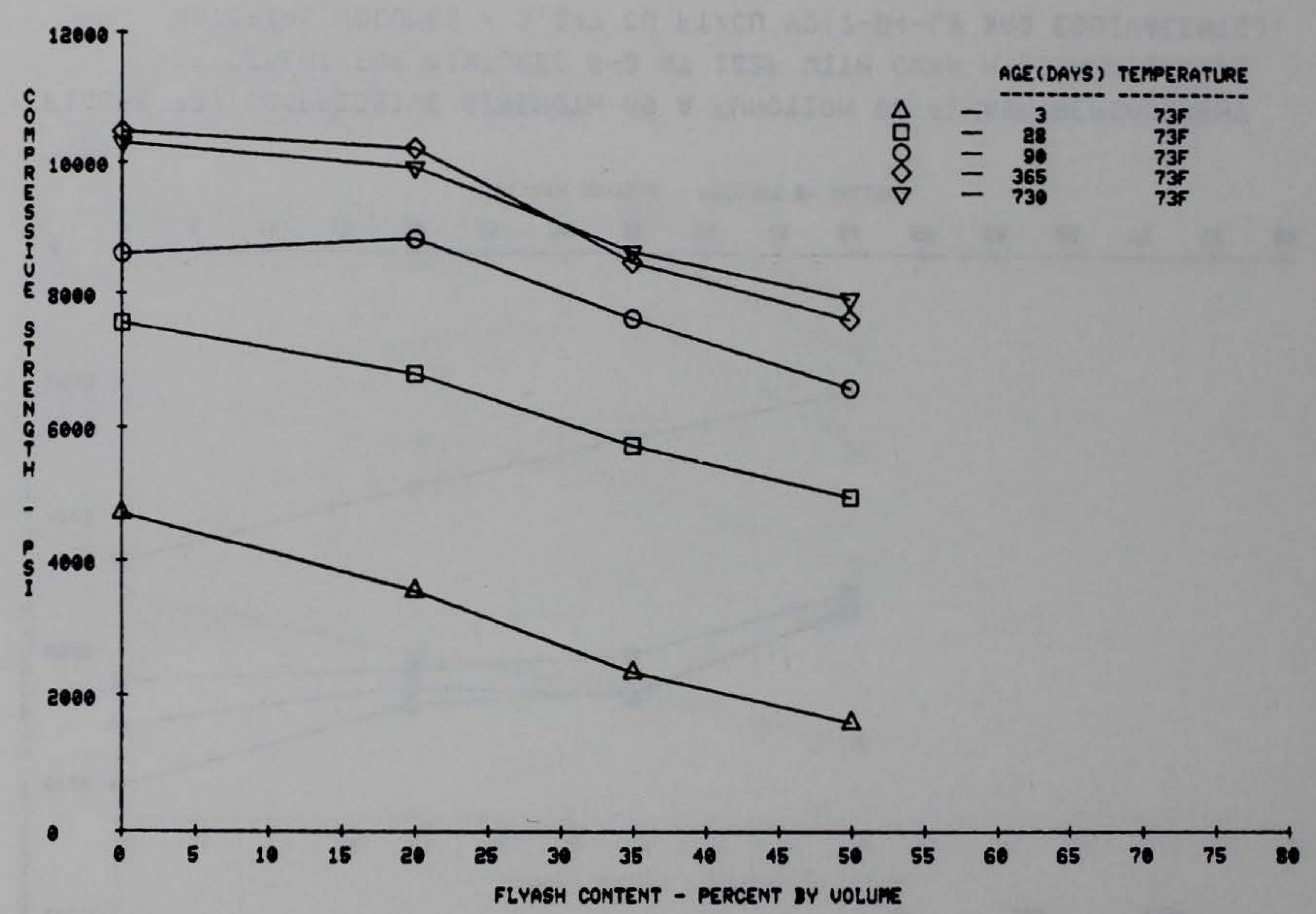

FIGURE 8A. COMPRESSIUE STRENGTH AS A FUNCTION OF FLYASH REPLACEMENT OF CEMENT FOR MIXTURES 13-16 AT 73F WITH HRWRA AT CEMENTITIOUS MATERIAL VOLUMES - 3.347 CU FT/CU YD(7-94-LB BAG EQUIUALENTS). 


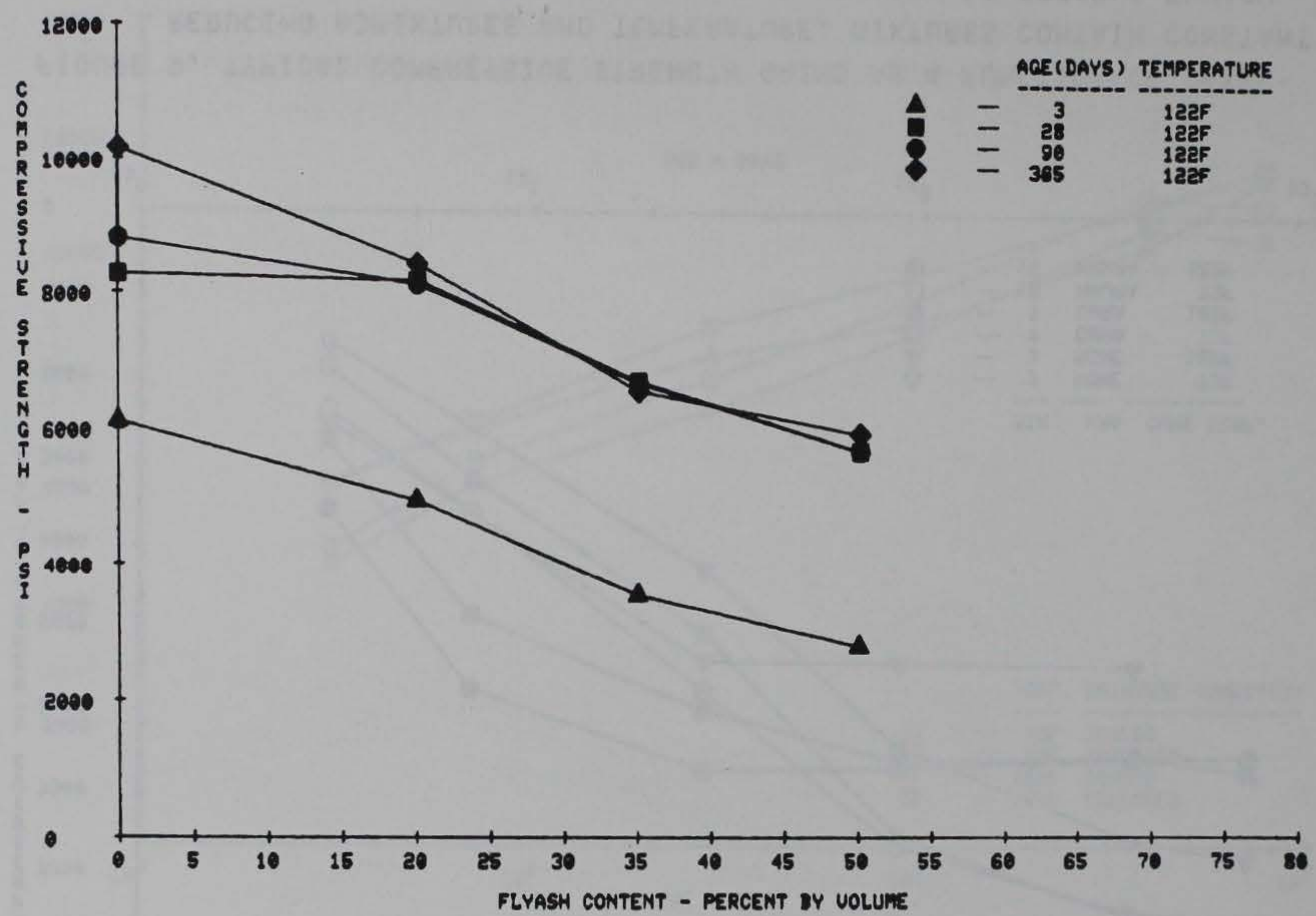

FIGURE 8B. COMPRESSIUE STRENGTH AS A FUNCTION OF FLYASH REPLACEMENT OF CEMENT FOR MIXTURES 13-16 AT I2EF WITH HRWRA AT CEMENTITIOUS MATERIAL UOLUMES - 3.347 CU FT/CU YD(7-94-LB BAG EQUIUALENTS). 


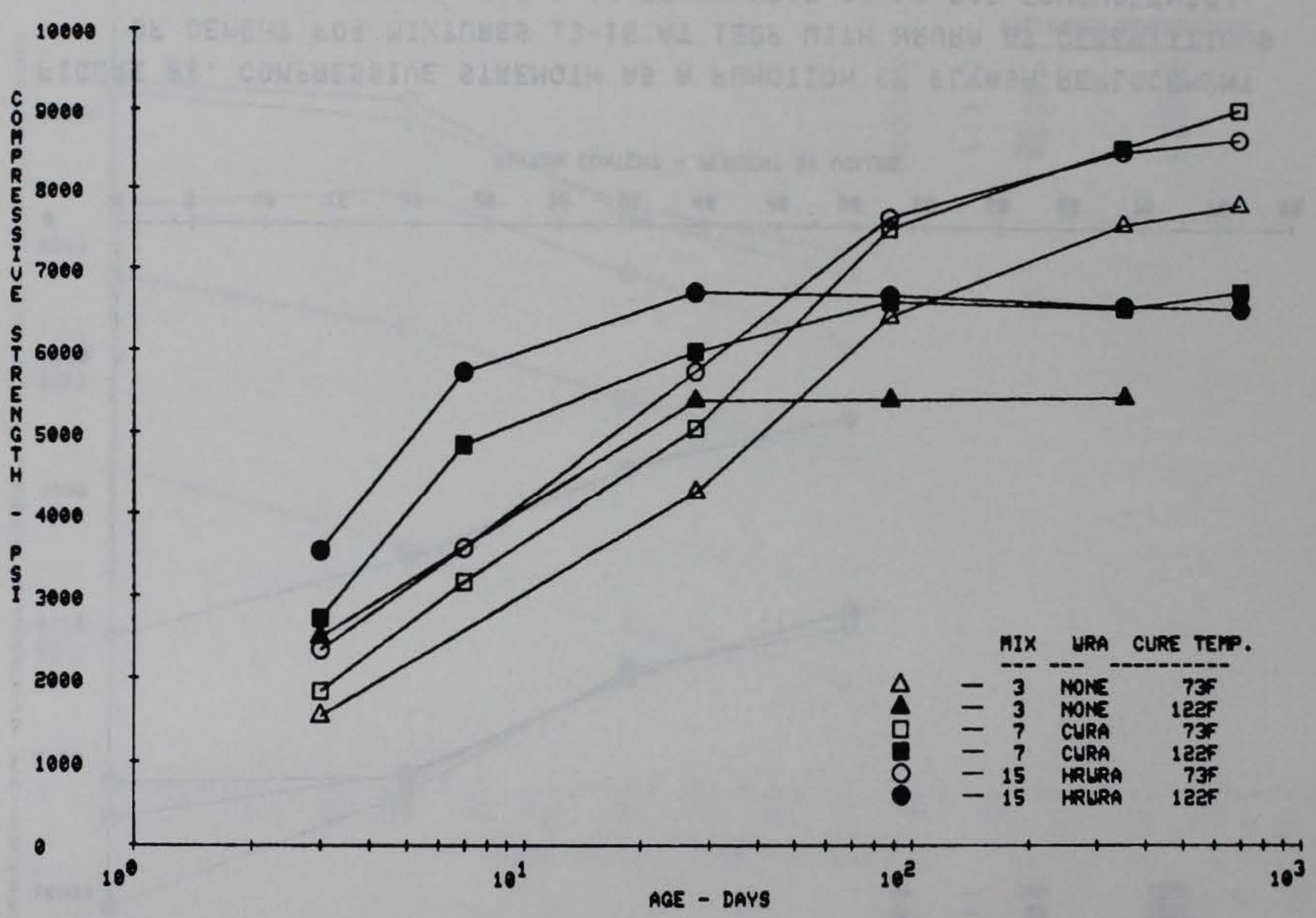

FIGURE 9. TYPICAL COMPRESSIUE STRENGTH GAINS AS A FUNCTION OF WATERREDUCING ADMIXTURES AND TEMPERATURE. MIXTURES CONTAIN CONSTANT CEMENTITIOUS VOLUME=3.347 CU FT/CU YD WITH 35 PERCENT FLYASH. 


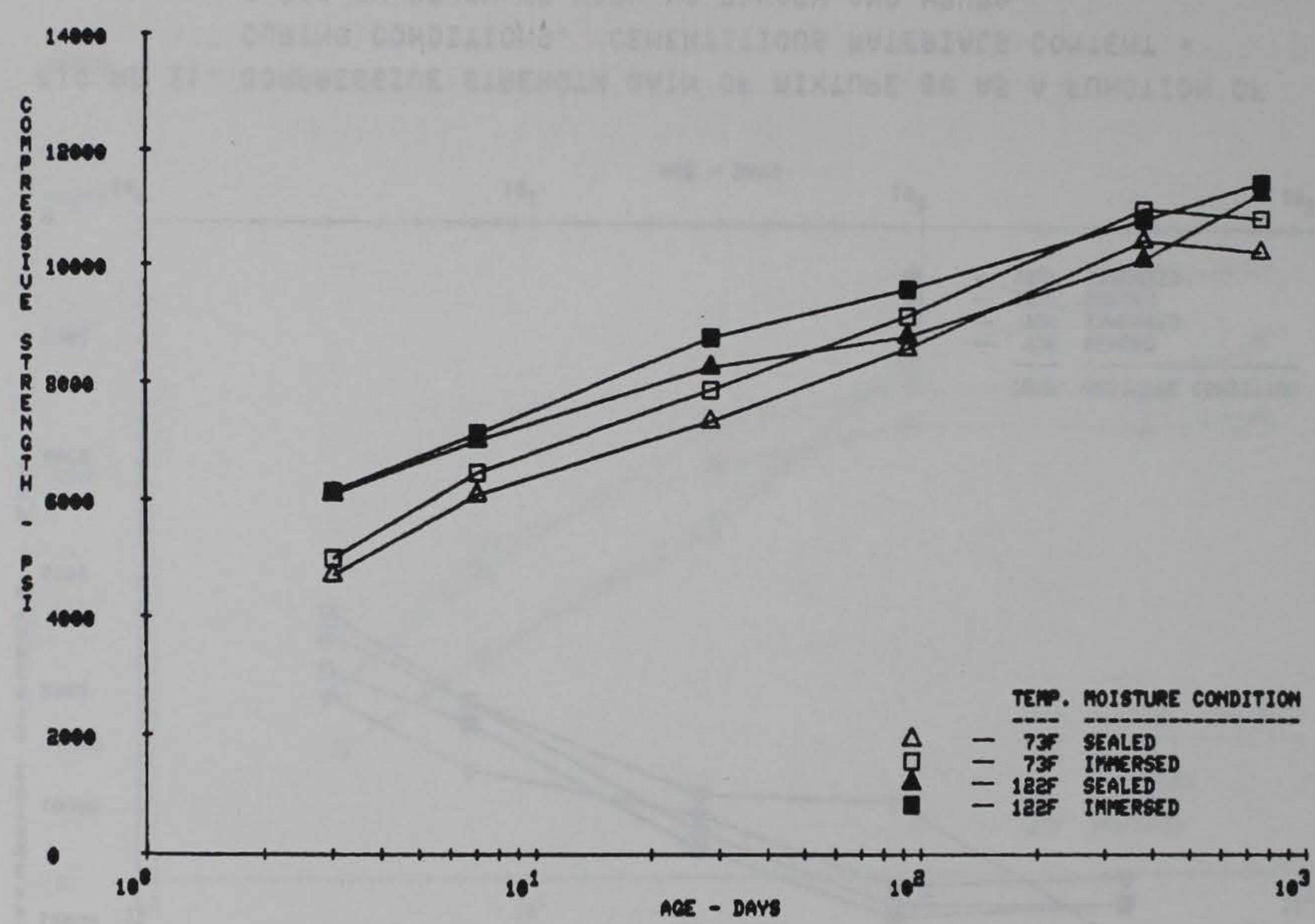

FIGURE 10. COMPRESSIUE STRENGTH GAIN OF MIXTURE 13 AS A FUNCTION OF CURING CONDITIONS. CEMENTITIOUS MATERIALS CONTENT 3.347 CU FT/CU YD WITH NO FLYASH AND HRWRA. 


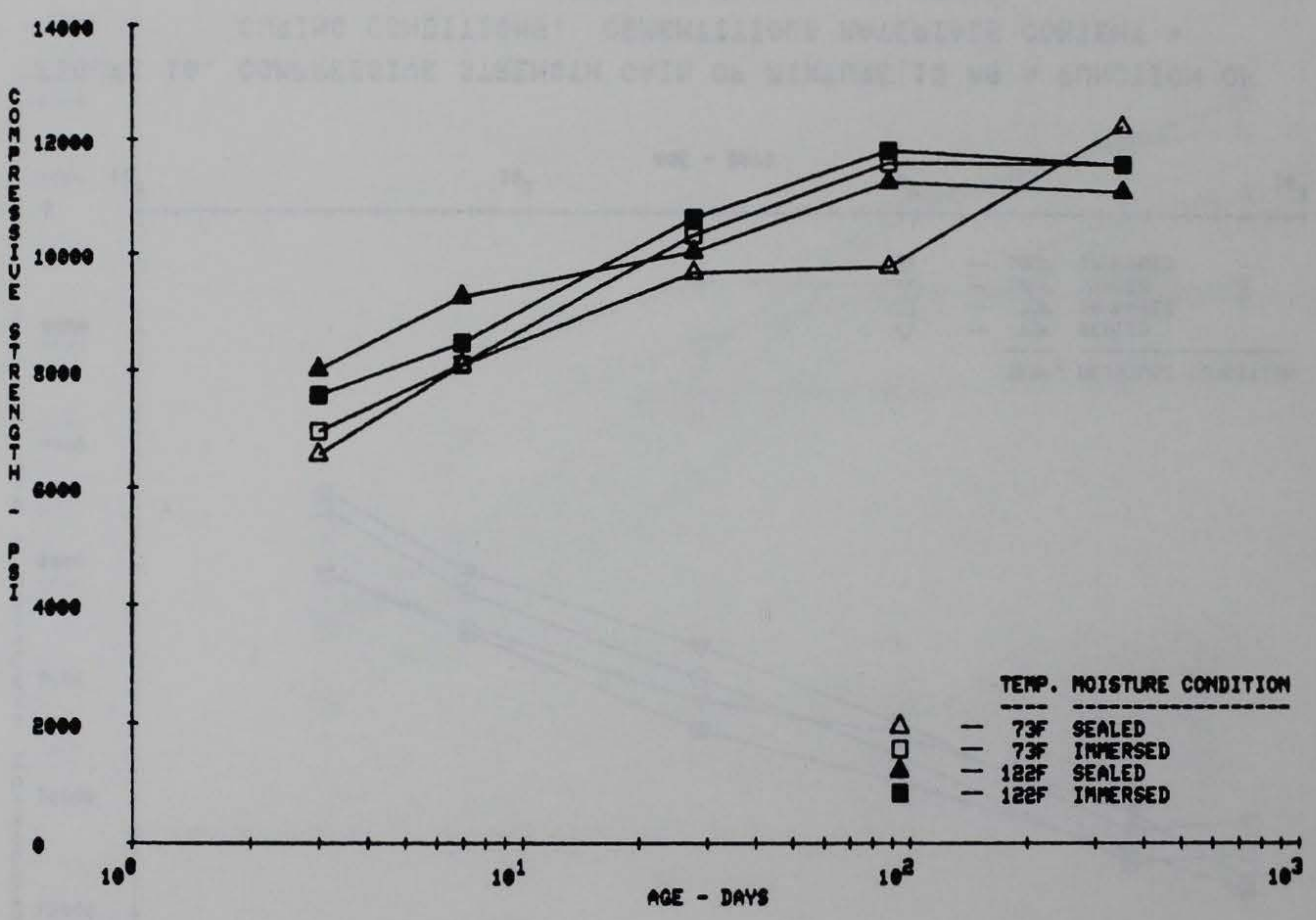

FIGURE 11. COMPRESSIUE STRENGTH GAIN OF MIXTURE 20 AS A FUNCTION OF CURING CONDITIONS. CEMENTITIOUS MATERIALS CONTENT 4.920 CU FT/CU YD WITH NO FLYASH AND HRWRA. 


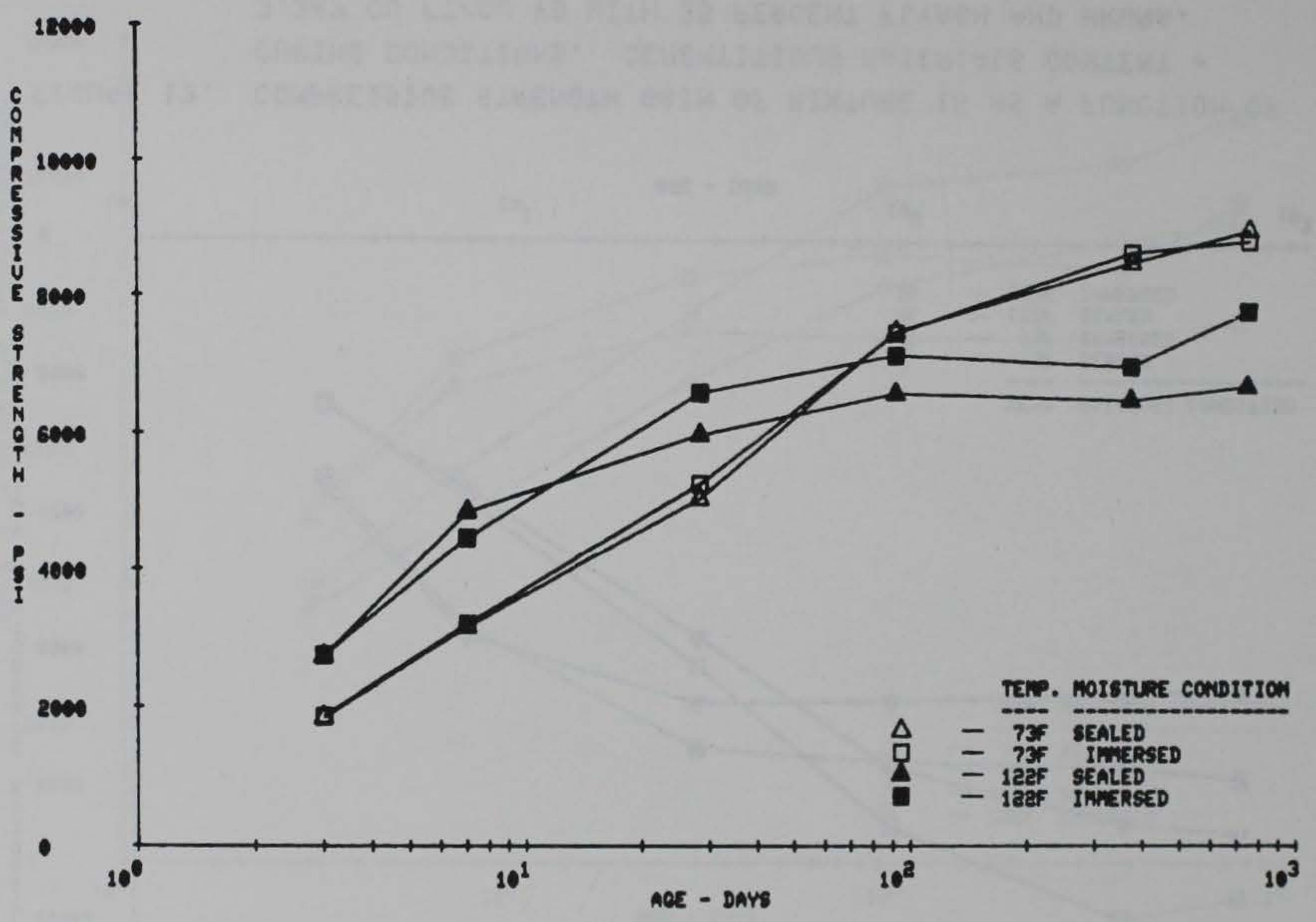

FIGURE 12. COMPRESSIUE STRENGTH GAIN OF MIXTURE ? AS A FUNCTION OF CURING CONDITIONS. CEMENTITIOUS MATERIALS CONTENT 3.34? CU FT/CU YD WITH 35 PERCENT FLYASH AND CWRA. 


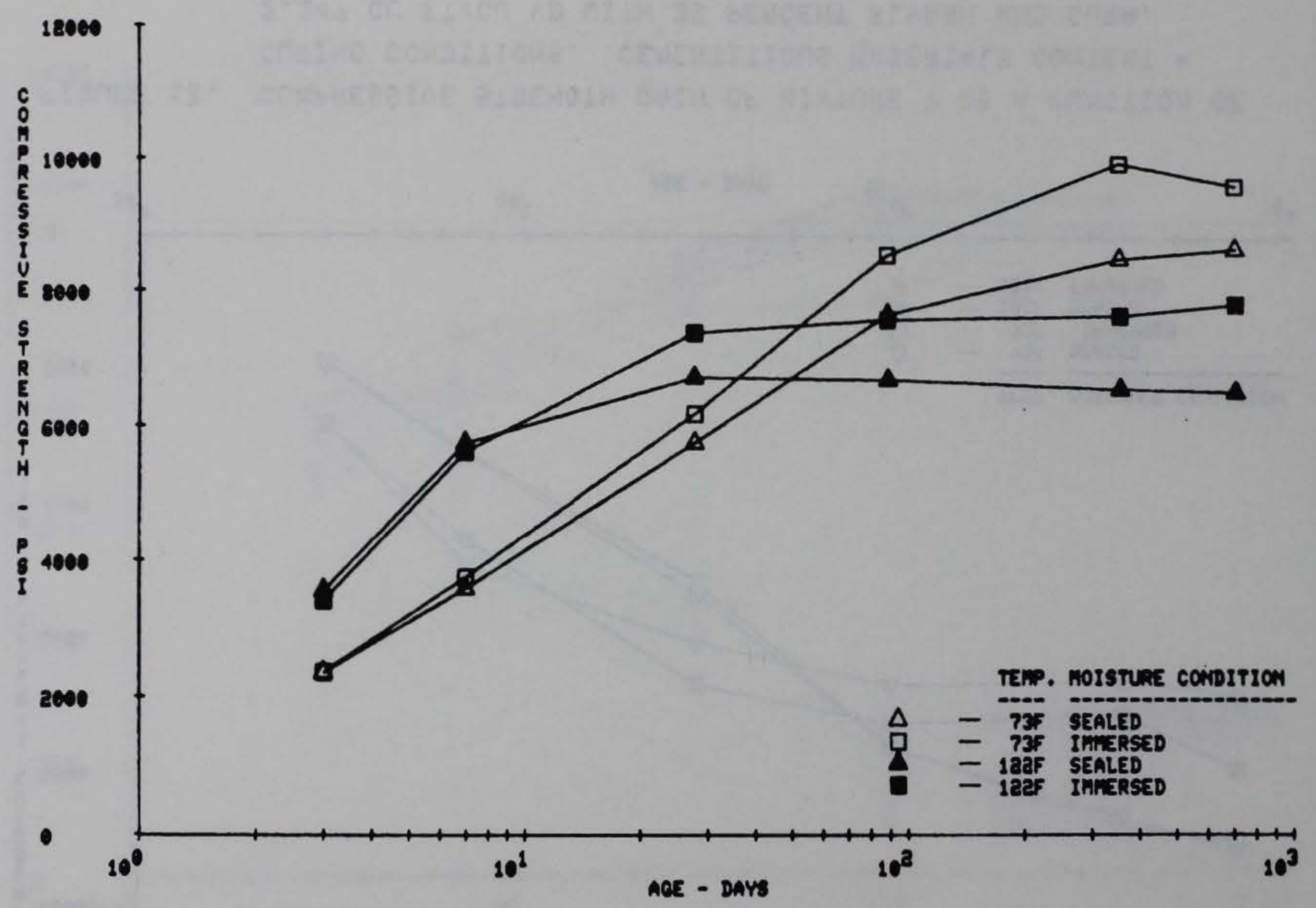

FIGURE 13. COMPRESSIUE STRENGTH GAIN OF MIXTURE 15 AS A FUNCTION OF CURING CONDITIONS. CEMENTITIOUS MATERIALS CONTENT 3.347 CU FT/CU YD WITH 35 PERCENT FLYASH AND HRWRA. 


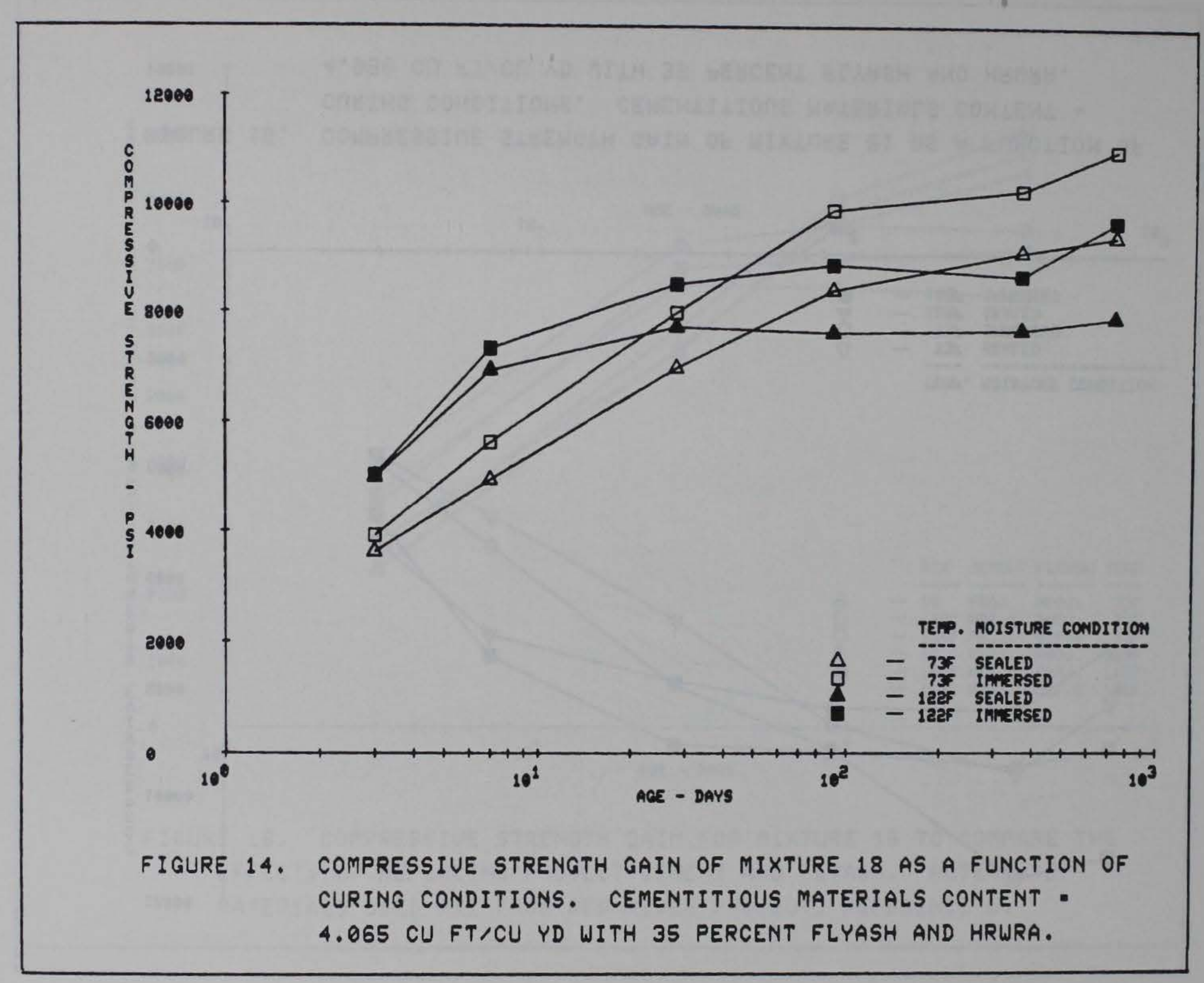




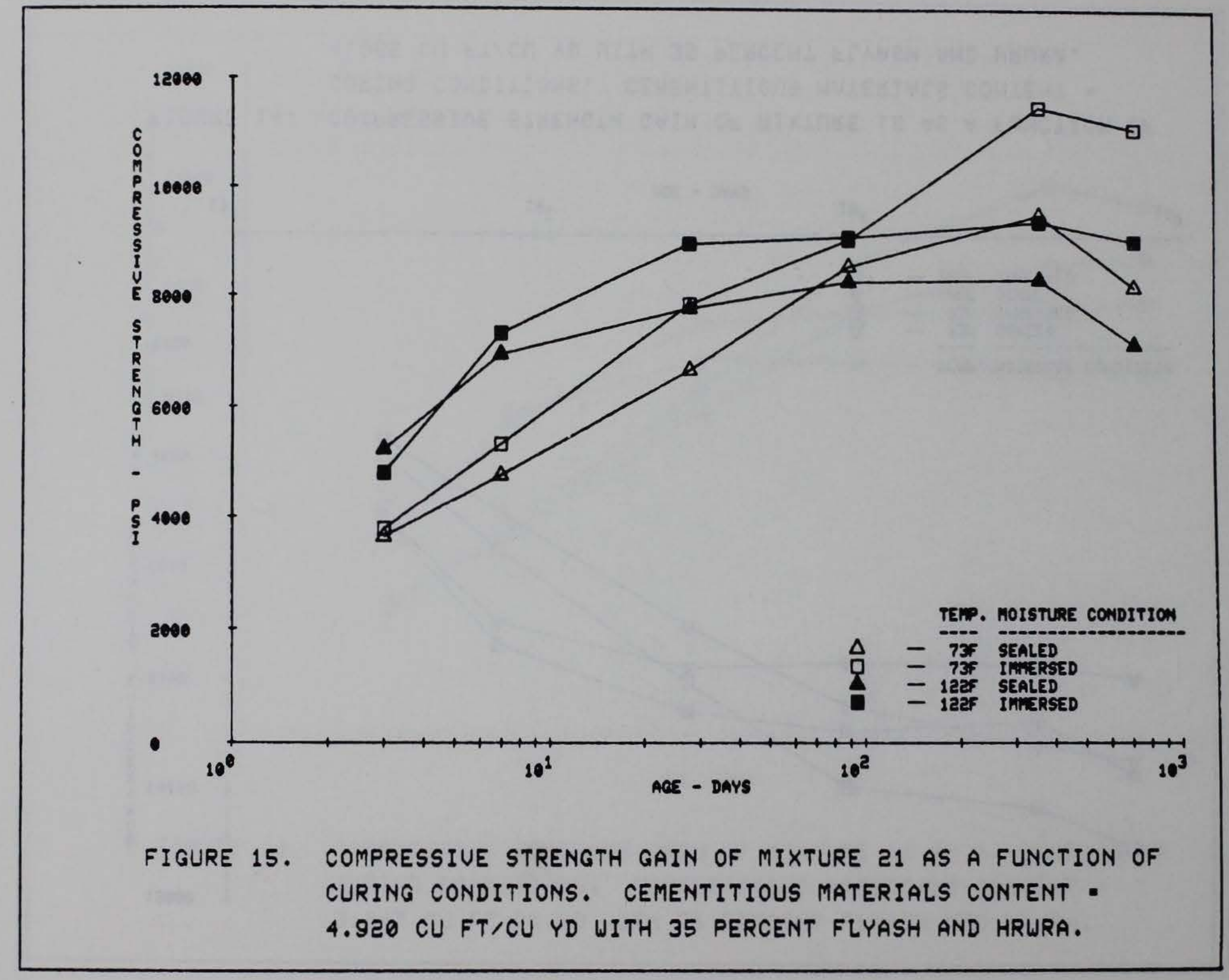




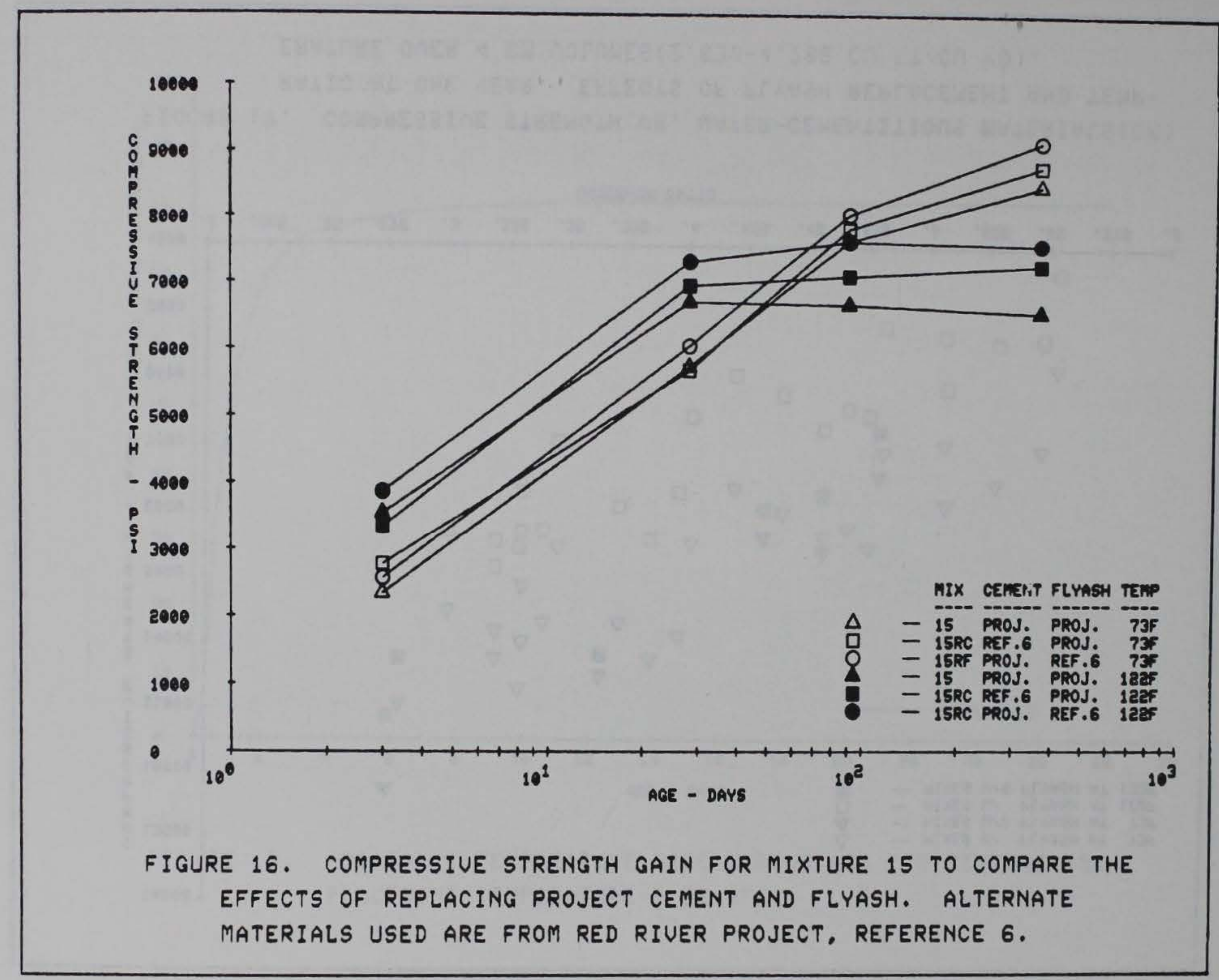




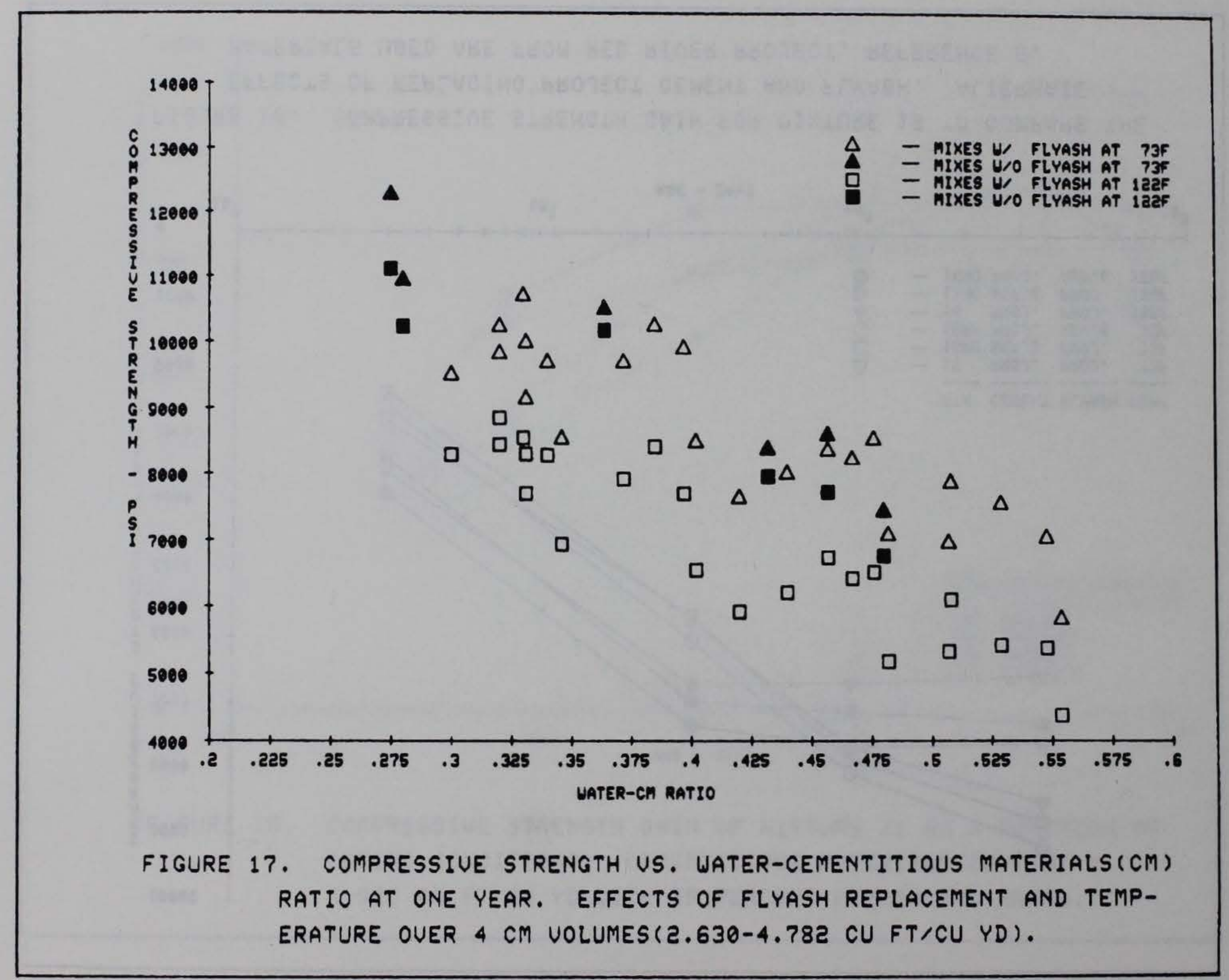




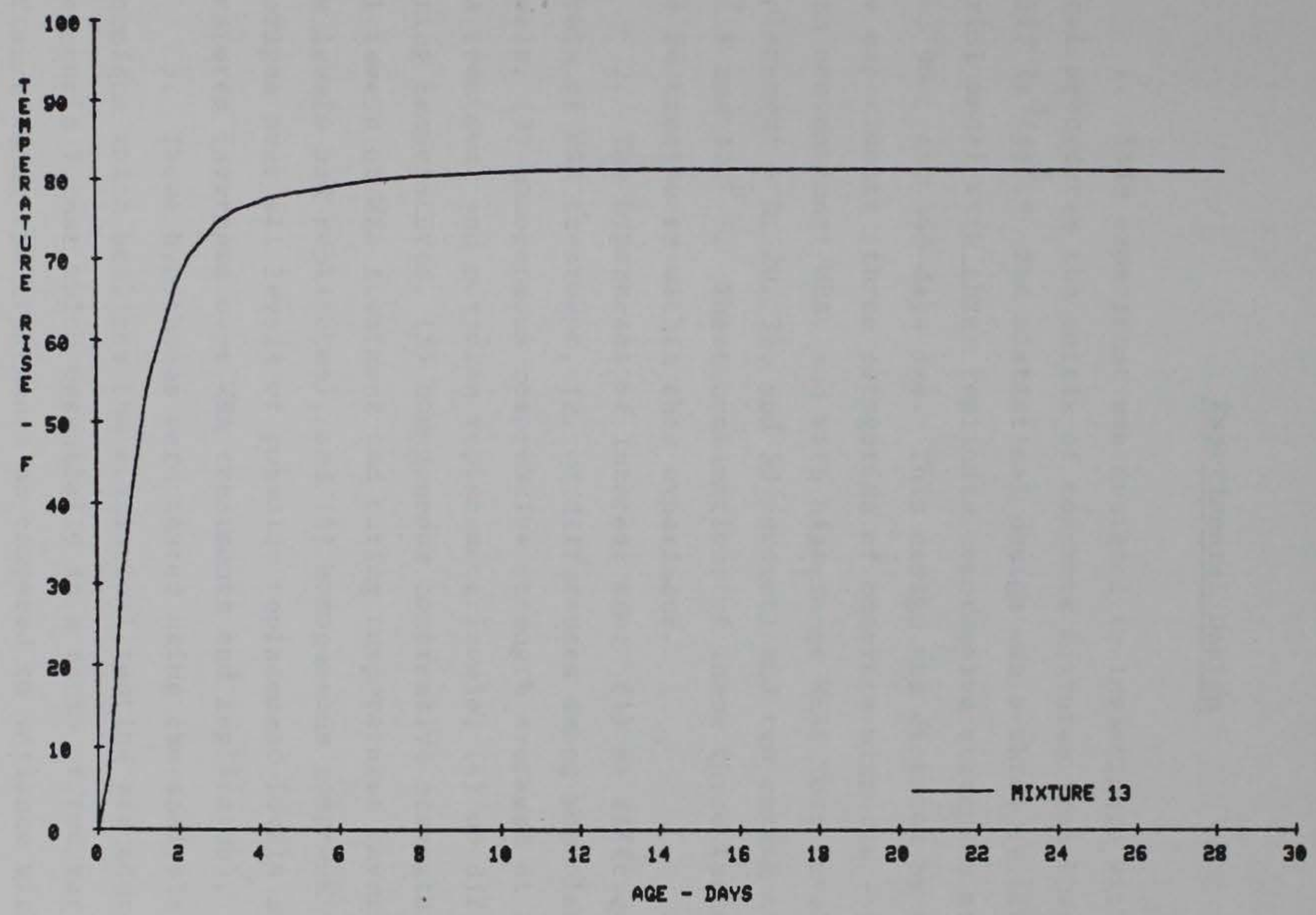

FIGURE 18. ADIABATIC TEMPERATURE RISE UERSUS AGE FOR MIXTURE 13. PLACEMENT TEMPERATURE - $58.4 F$. 
APPENDIX A: EXPERIMENT I, EVALUATIONS OF COMPRESSIVE STRENGTH GAIN OF PHASE I CONCRETE MIXTURES BY AGE WITH RESPECT TO WATER-REDUCING ADMIXTURES (WRA), CURING TEMPERATURES, AND POZZOLAN REPLACEMENT FOR A SINGLE CEMENTITIOUS MATERIALS CONTENT BY SOLID VOLUME (CM)

\section{Experimental Design}

1. This experiment was designed to investigate with valid statistical procedures the matrix of concrete mixtures from Phase I with $\mathrm{CM}=$ $3.347 \mathrm{ft}^{3} / \mathrm{yd}^{3}$.* The statistical design was a three by four by two factorial model with three replicate compressive strengths at each of 3-, 28-, 90-, and 365-days age. This design was dictated by the nature of the experiment: three categories of concrete mixtures - with no WRA, with conventional WRA, and with high-range WRA; four levels of pozzolan replacement - 0, 20, 35, and 50 percent; and two curing temperatures $73^{\circ} \mathrm{F}$ and $122^{\circ} \mathrm{F}$. These combinations of these three factors constitute the 24 treatments within this experiment.

2. The hypotheses of interest are: (1) no differences among levels of WRA treatment, (2) no differences among pozzolan replacement levels, (3) homogeneous compressive strength averages at all levels of WRA treatment and pozzolan replacement levels, (4) no differences between curing temperatures, (5) homogeneous compressive strength averages at all levels of WRA treatment and curing temperatures (averaged over pozzolan levels and replicates), and (6) homogeneous compressive strength averages over all levels of pozzolan replacement levels and curing temperatures (averaged over WRA treatments and replicates).

3. These hypotheses were tested using the analysis of variance technique which utilizes the statistical testing procedure known as the Snedecor's F-test which essentially is a ratio of two variance estimatorsvariance among the treatments as compared to variance within the treatments. A significant F-ratio is a numerical value which has been determined to be a rare event with regards to the assumptions being made.

* Equivalent to a solid volume of 7.0 94-1b bags of cementitious material. 
This is simply determined by comparison of the calculated F-ratio to a tabulated critical F-value. If the calculated F-value is larger than the tabulated F-value, the hypothesis under question is then rejected. If the hypothesis is rejected, then multiple comparisons of treatment means will be done using John Tukey's W-procedure. This entails the calculation of $W$ which is defined by the following equations:

$$
W=Q(t, d f) \sqrt{M S E / n}
$$

where

$$
\begin{aligned}
\mathrm{Q}(\mathrm{t}, \mathrm{df})= & \text { an upper percentage point of the studentized range with } \\
& \mathrm{t} \text { treatments and df degrees of freedom } \\
\mathrm{MSE}= & \text { the mean square of the error as estimated by the analy- } \\
& \text { sis of variance } \\
\mathrm{n}= & \text { the number of observations comprising the averages in } \\
& \text { question }
\end{aligned}
$$

\begin{tabular}{|c|c|c|c|}
\hline Sources of Variation & $\begin{array}{c}\text { Degrees of } \\
\text { Freedom } \\
\end{array}$ & Mean Squares & F-Ratio \\
\hline Among levels of WRA treatment (WRA) & 2 & MSWRA & MSWRA/MSE \\
\hline Among pozzolan levels (P) & 3 & MSP & MSP/MSE \\
\hline WRA by pozzolan interaction (WRAP) & 6 & MSWRAP & MSWRAP/MSE \\
\hline Among curing temperatures ( $\mathrm{T}$ ) & 1 & MST & MST/MSE \\
\hline WRA by temperature interaction (WRAT) & 2 & MSWRAT & MSWRAT/MSE \\
\hline $\begin{array}{l}\text { Pozzolan by temperature interaction } \\
\text { (PT) }\end{array}$ & 3 & MSPT & MSPT/MSE \\
\hline $\begin{array}{l}\text { WRA by pozzolan by temperature } \\
\text { interaction (WRAPT) }\end{array}$ & 6 & MSWRAPT & MSWRAPT/MSE \\
\hline Error & 48 & MSE & \\
\hline
\end{tabular}

4. These hypotheses are tested for each age component: 3 days, 28 days, 90 days, and 365 days. Hypotheses 1, 2, and 4 are called main effects, and hypotheses 3, 5, and 6 are called interaction effects. The sources of variation within the analysis of variance are: 
Where MS followed by a letter or combination of letters represents mean squares for the given source of variation. See Reference $8 *$ for a further treatment of the analysis of variance.

5. Before the analysis phase of Experiment I began, the experimental data were loaded onto the WES IBM-4331 computer system and a11 analysis of variance tables were generated by the Statistical Analysis System (SAS). Main effects which are significant were subsequently analyzed via an internal SAS mean separation procedure known as Duncan's Multiple Range Test which is similar to John Tukey's W-procedure.

\section{Statistical Analysis and Main Effects}

6. When considering these data by ages of $3,28,90$, and 365 days, the following conclusions can be drawn.

a. Concrete mixtures differentiated by WRA treatment are significantly different. That is, the mean compressive strengths for concrete mixtures with no water-reducing admixtures, conventional water-reducing admixtures, and highrange water-reducing admixtures are significantly different.

b. The mean compressive strengths for the different pozzolan replacement levels are significantly different.

c. The mean compressive strengths for the two curing temperatures are significantly different.

7. The significant order relation of these mean compressive strengths are summarized according to Duncan's Multiple Range Test in Tables Al-A3.

\section{Analysis and Interpretation of Second Order Interaction}

8. Further interpretation of the interaction terms are shown in Tables A4-A6.

9. As can readily be seen from Table A4, the concrete mixtures with the high-range WRA consistently produced material with higher compressive strengths for each of the four ages and within all levels of

* Table of references on page 30 of text. 
Table Al

Significant Order Relationships of Mean Compressive

Strengths for the Main Effect of Concrete Mixtures

\begin{tabular}{cccccc}
\hline \multirow{2}{*}{ Age } & \multicolumn{3}{c}{ Levels of WRA Treatment } \\
\cline { 2 - 6 } 3 days & No WRA & & $\frac{\text { Conventional WRA }}{2692}$ & $\frac{\text { High-Range WRA }}{369}$ \\
28 days & 4958 & $<$ & 5557 & $<$ & 3694 \\
90 days & 5716 & $<$ & 6575 & $<$ & 6701 \\
365 days & 6407 & $<$ & 7266 & $<$ & 8608
\end{tabular}

Note: Within each age period, the analysis of variance indicates that the mean compressive strengths are significantly different and that Duncan's Multiple Range Test indicates the above significant order relation. Compressive strengths are averaged over pozzolan replacement levels, curing temperatures, and replicates.

Table A2

Significant Order Relationships of Mean

Compresive Strengths for the Main Effect

of Pozzolan Replacement Levels

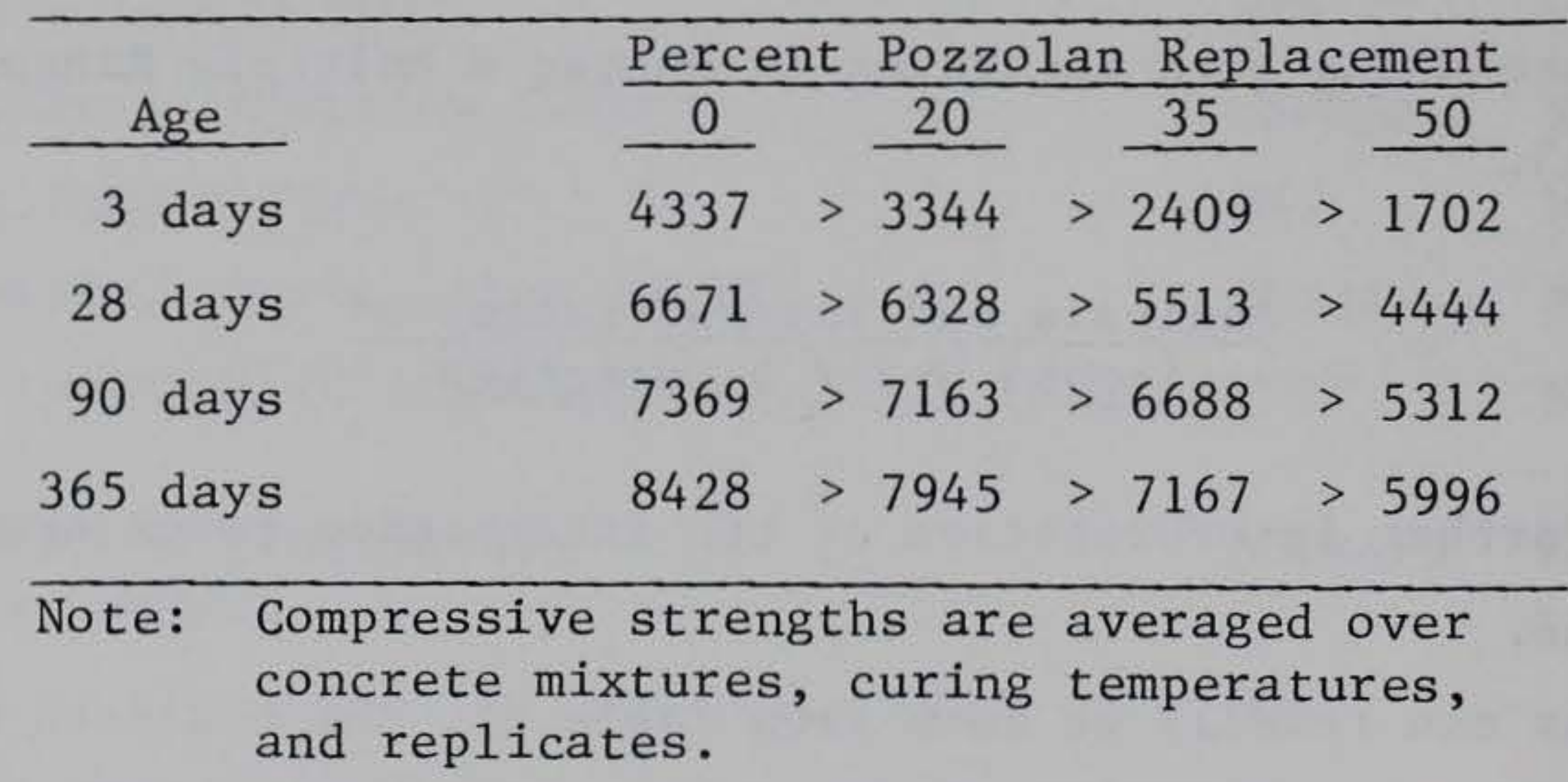


Table A3

Significant Order Relationhips

of Mean Compressive Strength for

the Main Effect of Temperature

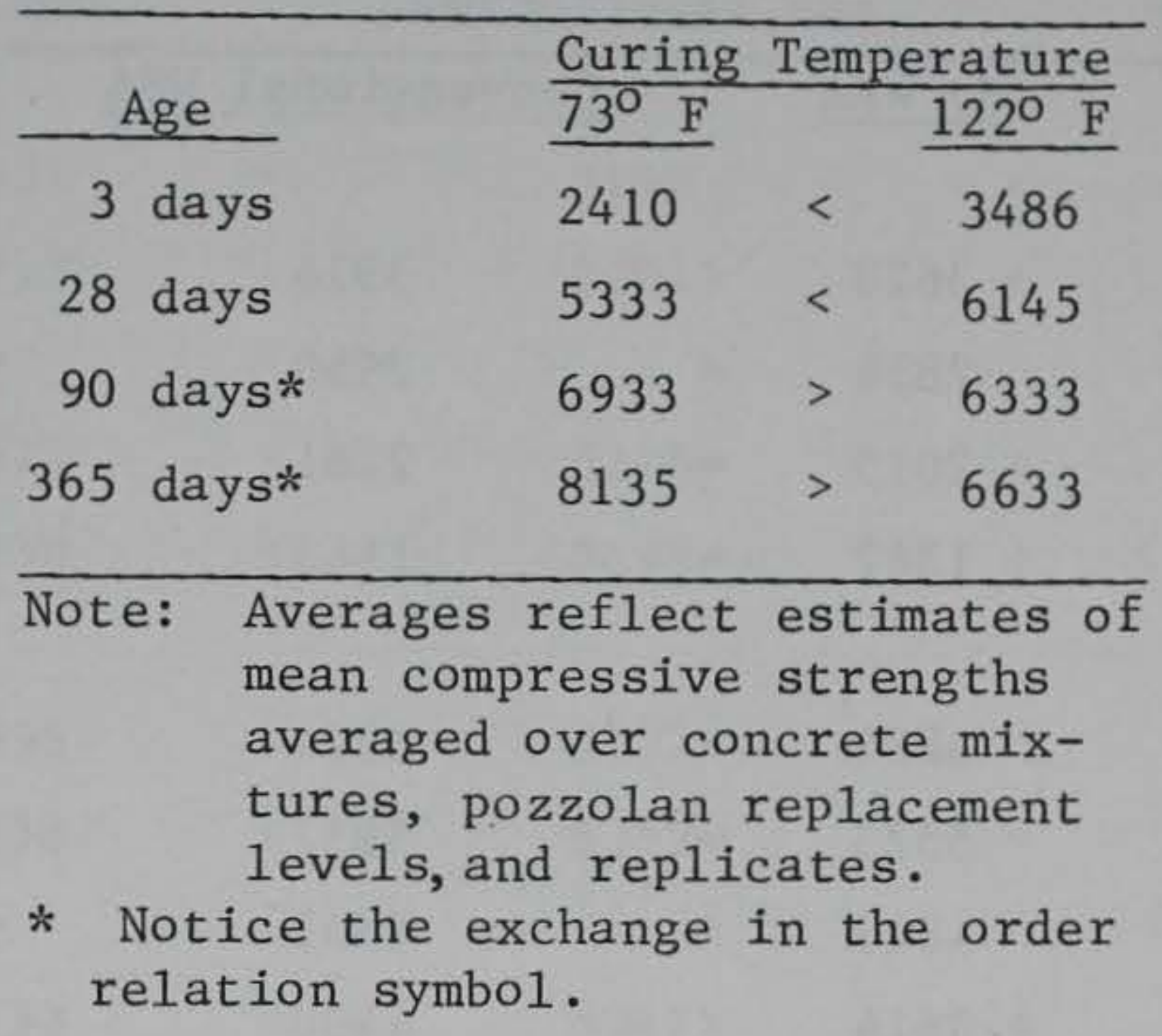

pozzolan replacement. Also, within the high-range WRA the 0 percent pozzolan replacement level produced concrete with significantly higher compressive strength than the other pozzolan replacement levels with high-range WRA. Furthermore, the high-range WRA mixtures consistently exhibited significantly higher compressive strengths than mixtures with no WRA or conventional WRA at both curing temperatures (see Table A5). The $122^{\circ} \mathrm{F}$ cured concrete exhibited significantly higher compressive strength than the $73^{\circ}$ cured concrete. However, this pattern was only true for the ages of 3 days and 28 days. After that, the $73^{\circ} \mathrm{F}$ cured concrete exhibited the significantly higher mean compressive strength. This pattern is further established with the pozzolan replacement by curing temperature interaction (Table A6). 
Table A4

Average Compressive Strength (psi) for

Pozzolan Replacement Level by WRA Treatment

(Averaged Over Temperature)

\begin{tabular}{|c|c|c|c|c|c|}
\hline Pozzolan Level & No WRA & & Conventional WRA & & High-Range WRA \\
\hline \multicolumn{6}{|l|}{ Age $=3$ days } \\
\hline 0 & 3628 & $<$ & 3976 & $<$ & 5408 \\
\hline 20 & 2838 & $=$ & 2950 & $<$ & 4243 \\
\hline 35 & 2015 & $=$ & 2281 & $<$ & 2931 \\
\hline 50 & 1347 & $=$ & 1562 & $<$ & 2197 \\
\hline \multicolumn{6}{|l|}{ Age $=28$ days } \\
\hline 0 & 5824 & $=$ & 6374 & $<$ & 7809 \\
\hline 20 & 5573 & $=$ & 5937 & $<$ & 7475 \\
\hline 35 & 4823 & $<$ & 5507 & $<$ & 6209 \\
\hline 50 & 3614 & $<$ & 4406 & $<$ & 5311 \\
\hline \multicolumn{6}{|l|}{ Age $=90$ days } \\
\hline 0 & 6314 & $<$ & 7092 & $<$ & 8700 \\
\hline 20 & 6284 & $=$ & 6745 & $<$ & 8460 \\
\hline 35 & 5891 & $<$ & 7033 & $=$ & 7140 \\
\hline 50 & 4376 & $<$ & 5428 & $<$ & 6132 \\
\hline \multicolumn{6}{|l|}{$\underline{\text { Age }=365 \text { days }}$} \\
\hline 0 & 7089 & $<$ & 7874 & $<$ & 10320 \\
\hline 20 & 6983 & $<$ & 7537 & $<$ & 9315 \\
\hline 35 & 6479 & $<$ & 7514 & $<$ & 7508 \\
\hline 50 & 5078 & $<$ & 6140 & $<$ & 6771 \\
\hline
\end{tabular}

Symbols: = not statistically different.

< statistically smaller than. 
Table A5

Average Compressive Strength (psi) for

Curing Temperature by WRA Treatment

(Averaged Over Pozzolan Replacement)

No WRA

$\underline{\text { Age }=3 \text { days }}$

$73^{\circ} \mathrm{F}$

$122^{\circ} \mathrm{F}$

2001

2913

Age $=28$ days

$$
73^{\circ} \mathrm{F}
$$

$122^{\circ} \mathrm{F}$

4579

5338

$\underline{\text { Age }=90 \text { days }}$

$$
73^{\circ} \mathrm{F}
$$

$122^{\circ} \mathrm{F}$

6095

5338

Age $=365$ days

$73^{\circ} \mathrm{F}$

7158

5656
Conventional WRA

2180

3204

5216

5899

6797

6352

8047

6485
High-Range WRA

$<\quad 3049$

$<\quad 4340$

6204

7199

7907

7309

8812

7758 
Table A6

Average Compressive Strengths (psi) for

Curing Temperature by Pozzolan Replacement

\begin{tabular}{|c|c|c|c|c|c|c|c|}
\hline Curing Temperature & $\frac{\text { Perce }}{0}$ & $n t$ & $\frac{\text { Pozzo }}{20}$ & 1ai & $\frac{\text { Rep }}{35}$ & $\mathrm{ace}$ & $\frac{\text { ement }}{50}$ \\
\hline \multicolumn{8}{|l|}{$\underline{\text { Age }}=3$ days } \\
\hline $73^{\circ} \mathrm{F}$ & 3729 & $>$ & 2780 & $>$ & 1908 & $>$ & 1224 \\
\hline $122^{\circ} \mathrm{F}$ & 4946 & $>$ & 3908 & $>$ & 2910 & $>$ & 2180 \\
\hline \multicolumn{8}{|l|}{ Age $=28$ days } \\
\hline $73^{\circ} \mathrm{F}$ & 6463 & $>$ & 5925 & $>$ & 5012 & $>$ & 3931 \\
\hline $122^{\circ} \mathrm{F}$ & 6879 & $=$ & 6732 & $>$ & 6014 & $>$ & 4956 \\
\hline \multicolumn{8}{|l|}{ Age $=90$ days } \\
\hline $73^{\circ} \mathrm{F}$ & 7464 & $=$ & 7531 & $>$ & 7168 & $>$ & 5569 \\
\hline $122^{\circ} \mathrm{F}$ & 7273 & $>$ & 6796 & $>$ & 6208 & $>$ & 5055 \\
\hline \multicolumn{8}{|l|}{ Age $=365$ days } \\
\hline $73^{\circ} \mathrm{F}$ & 8759 & $=$ & 8812 & $>$ & 8177 & $>$ & 6792 \\
\hline $122^{\circ} \mathrm{F}$ & 8096 & $>$ & 7079 & $>$ & 6157 & $>$ & 5201 \\
\hline
\end{tabular}




\section{Analysis and Interpretation of}

\section{Third-Order Interaction}

10. For the third-order interaction cell means of water-reducing admixture by curing temperature by percent pozzolan replacement shown in Table A7, the following conclusions can be drawn.

11. At age 3 days, the compressive strengths of concrete with conventional WRA cured at $73^{\circ} \mathrm{F}$ showed an increase in strength as percent pozzolan replacement decreased. This increasing compressive strength relationship with decreasing percent pozzolan replacement was also prevalent with concrete with conventional WRA cured at $122^{\circ}$, concrete with high-range WRA cured at both $73^{\circ}$ and $122^{\circ} \mathrm{F}$, and concrete with no WRA cured at both $73^{\circ}$ and $122^{\circ} \mathrm{F}$.

12. At age 28 days, the trend of increasing compressive strength with decreasing percent pozzolan replacement tended to display compromises. For concrete with conventional WRA cured at $73^{\circ} \mathrm{F}$ the increasing compressive strength trend with decreasing percent pozzolan replacement was prevalent. However, when cured at $122^{\circ} \mathrm{F}$, compressive strengths from 0-, 20-, and 35-percent pozzolan replacement were not statistically different, but all were significantly larger than the compressive strengths at 50-percent pozzolan replacement. For concrete with the high-range WRA cured at both $73^{\circ}$ and $122^{\circ} \mathrm{F}$, compressive strengths displayed an increasing trend with decreasing pozzolan replacement with 0 - and 20-percent pozzolan replacement levels displaying equivalent compressive strengths. This trend was also prevalent for concrete with no WRA cured at $73^{\circ} \mathrm{F}$. For concrete with no WRA cured at $122^{\circ} \mathrm{F}$, the trend showed equivalent compressive strengths at 0-, 20-, and 35-percent pozzolan replacement which were significantly larger than the compressive strengths at 50-percent pozzolan replacement.

13. At 90-days age, concrete with no WRA and conventional WRA cured at $73^{\circ}$ and $122^{\circ} \mathrm{F}$ displayed similar trends. In these four cases, compressive strengths at $0-, 20-$, and 35-percent pozzolan replacement levels were statistically equivalent, and all three of these levels were statistically larger than the compressive strength at the 50 -percent 


\begin{tabular}{rlll}
\hline WRA/Curing Temperature & $\frac{\text { Percent Pozzolan Replacement }}{0}$ & $\frac{0}{20}-\frac{35}{50}$ \\
days & $W^{*}=345.0$ &
\end{tabular}

Conventional

$$
\begin{array}{rlllll}
73^{\circ} & \underline{3341.7} & \underline{2426.0} & \underline{1842.0} & \underline{1111.7} \\
122^{\circ} & \underline{4610.0} & \underline{3474.3} & \underline{2720.3} & \underline{2012.7}
\end{array}
$$

High-Range

$\begin{array}{rrrrr}73^{\circ} & \underline{4715.0} & \underline{3546.7} & \underline{2338.7} & \underline{1597.0} \\ 122^{\circ} & \underline{6100.3} & \underline{4939.3} & \underline{3522.7} & \underline{2796.3}\end{array}$

No

$$
\begin{aligned}
& 73^{\circ} \\
& 122^{\circ} \\
& \underline{3130.0} \quad \underline{2366.7} \quad \underline{1543.3} \quad \underline{963.3}
\end{aligned}
$$

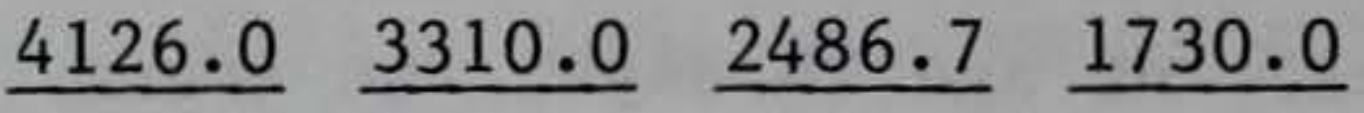

$$
\begin{aligned}
& 28 \text { days } w=618.5
\end{aligned}
$$

Conventiona1

$$
\begin{array}{rrrrr}
73^{\circ} & \underline{6366.0} & \underline{5678.7} & \underline{5042.3} & \underline{3775.0} \\
122^{\circ} & \underline{6392.3} & 6194.7 & 5971.0 & \underline{5036.3} \\
\hline
\end{array}
$$

High-Range

$$
\begin{array}{r}
73^{\circ} \\
122^{\circ}
\end{array}
$$

$\begin{array}{llll}7353.0 \quad 6787.0 & 5729.0 & 4945.7\end{array}$

$\underline{8266.7 \quad 8163.3} \quad \underline{6889.7} \quad \underline{5676.0}$

None

$73^{\circ}$
$122^{\circ}$

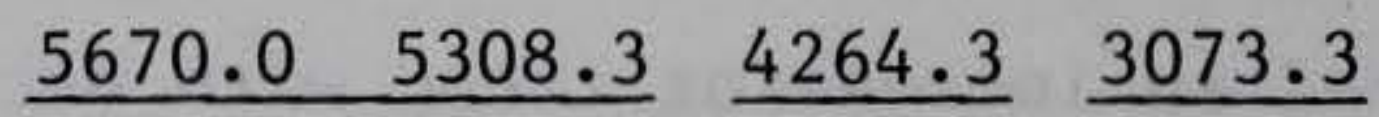

$\underline{5977.0 \quad 5838.0 \quad 5381.0 \quad 4155.0}$

90 days $w=614.2$

Conventional

$123^{\circ}$

$\begin{array}{llll}7141.0 \quad 7043.0 \quad 7482.7 & & 5522.7\end{array}$

$\begin{array}{lllll}7044.0 & 6447.3 & 6583.7 & 5334.0\end{array}$

High-Range

$$
\begin{array}{r}
73^{\circ} \\
122^{\circ}
\end{array}
$$

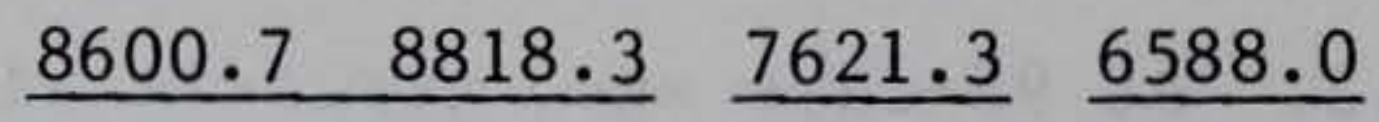

$\underline{8799.0} \quad \underline{8102.7} \quad \underline{659.3} \quad \underline{5675.7}$

None

$$
\begin{array}{r}
73^{\circ} \\
122^{\circ}
\end{array}
$$

$\underline{6651.7 \quad 6731.0 \quad 6401.0} \quad \underline{4597.3}$

$\underline{5977.0 \quad 5838.0 \quad 5381.0 \quad 4155.0}$ 
Table A7 (Concluded)

$\begin{aligned} \text { WRA/Curing Temperature } & \frac{\text { Percent Pozzolan Replacement }}{0} \frac{20}{35}-\frac{35}{365} \text { days } w=908.6\end{aligned}$

Conventiona1

\begin{tabular}{rlrll}
$73^{\circ}$ & $\underline{8,371.7}$ & $8,348.0$ & 8519.0 & $\underline{6951.0}$ \\
$122^{\circ}$ & $\underline{7,375.3}$ & $6,726.7$ & 6508.7 & $\underline{5329.7}$ \\
\hline
\end{tabular}

High-Range

\begin{tabular}{rlrrr}
$73^{\circ}$ & $10,482.3$ & $10,223.0$ & $\underline{8471.7}$ & 7617.0 \\
$122^{\circ}$ & $\underline{10,157.7}$ & $\underline{8,407.0}$ & $\underline{6543.7}$ & 5925.3 \\
\hline
\end{tabular}

None

\begin{tabular}{rrrrr}
$73^{\circ}$ & $\underline{7,422.3}$ & $7,864.3$ & 7540.3 & 5807.0 \\
$122^{\circ}$ & $\underline{6,756.3}$ & $6,102.0$ & 5417.7 & $\underline{4348.0}$ \\
\hline
\end{tabular}

\footnotetext{
Critical difference value,

$w=Q_{.05}(4,48) \sqrt{(\text { Mean Square Error)/3 }}$.

Notation: In the table means underscored by the same line are not significantly different.
}

pozzolan replacement level. With high-range WRA concrete the compressive strength trend was dependent on curing temperature. At $73^{\circ} \mathrm{F}$, compressive strengths at the 0 - and 20-percent pozzolan replacement levels were not statistically different; however, the compressive strengths at these pozzolan replacement levels were higher than the compressive strengths at both the 35- and 50-percent pozzolan replacement levels which were also significantly different. For concrete cured at $122^{\circ} \mathrm{F}$, the trend was strictly increasing compressive strength as percent pozzolan replacement decreased.

14. At 365-days age, concrete with conventional WRA cured at both $73^{\circ}$ and $122^{\circ} \mathrm{F}$ retained its 90 -day age trend. Furthermore, the 90-day age trend for the no WRA cured at $73^{\circ} \mathrm{F}$ was evidenced. The remaining three cases developed entirely new trends. For the concrete with highrange WRA cured at $73^{\circ} \mathrm{F}$, the compressive strength for the 0 - and 20percent pozzolan replacement levels were statistically not different, 
however, they were statistically higher than the compressive strengths observed at the 35- and 50-percent pozzolan replacement levels which were statistically not different. For concrete with high-range WRA cured at $122^{\circ} \mathrm{F}$, the 35 - and 50-percent pozzolan replacement levels showed equivalent compressive strengths; however, the compressive strengths then significantly increased as percent pozzolan decreased. For the concrete with no WRA cured at $122^{\circ} \mathrm{F}$, the pattern was essentially an increasing compressive strength relationship with decreasing percent pozzolan replacement with an exception at the 20-percent pozzolan replacement level. This level displayed material which was not different from either the 0 - or 35-percent pozzolan levels which were different.

\section{Age Trend Analysis}

15. Ancillary to this analysis, a plot of average compressive strengths versus age was constructed (Figure A1) so that information pertaining to strength and age could be informally obtained. From this plot, it appeared that compressive strength was related logarithmically with age. To substantiate this, correlation coefficients were computed for each of the 24 combinations of mixture and curing temperature. Table A8 displays the correlation coefficients. As is readily seen, the smallest coefficient is 0.8285 and the largest is 0.9956 . These coefficients, which measure the linearity of two variables, are definitely indicating that a logarithmic model fits extremely well. The mathematical model is

$$
\text { Compressive Strength }=\mathrm{A}+\mathrm{B} \cdot \mathrm{LN}(\text { age })
$$

where

$$
\begin{aligned}
& \mathrm{A}=\text { intercept when } \operatorname{LN}(\text { age })=0 \\
& \mathrm{~B}=\text { slope }
\end{aligned}
$$

$\mathrm{LN}(\cdot)=$ natural logarithm 


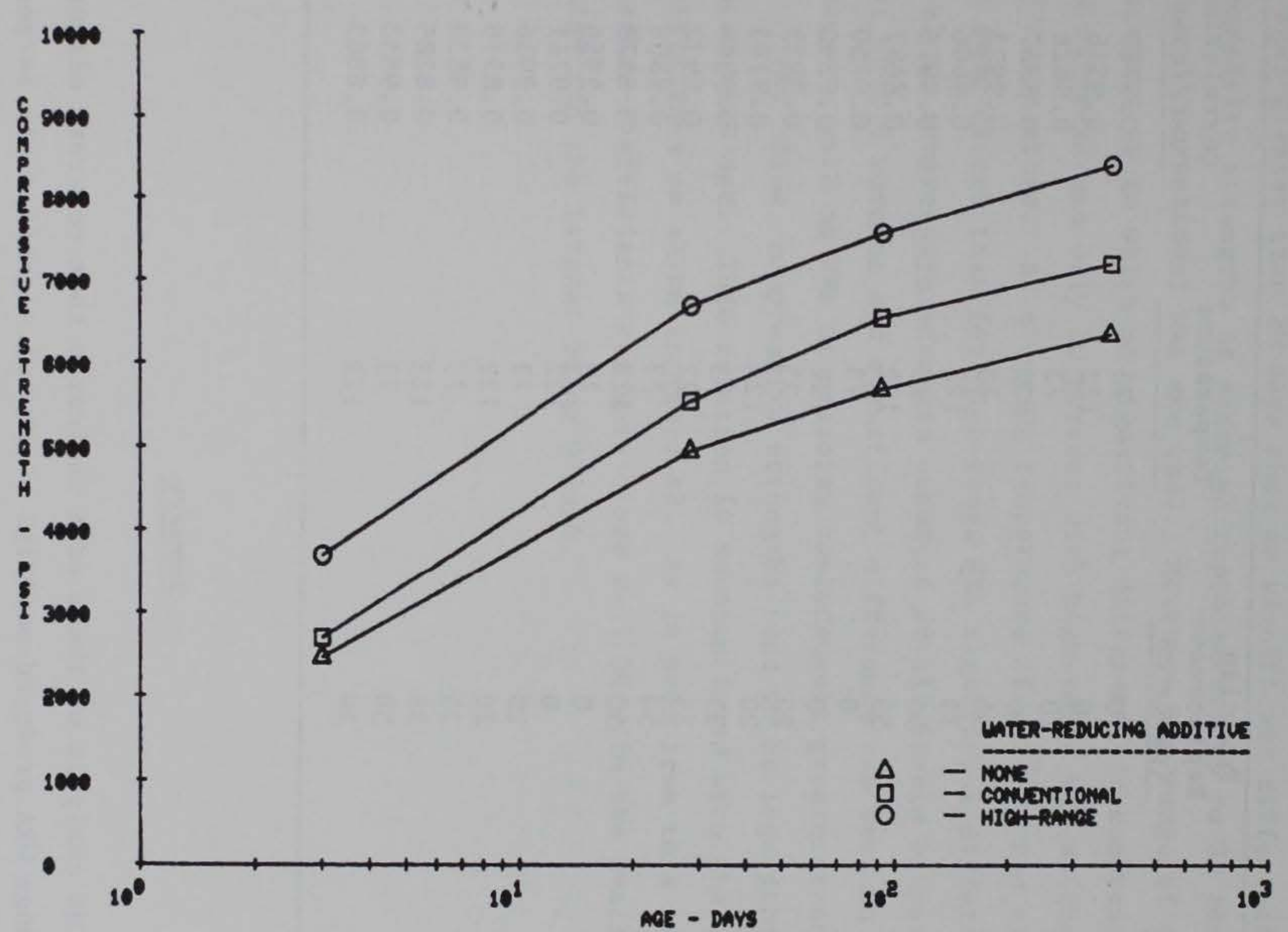

FIGURE A1. COMPRESSIUE STRENGTH GAIN OF CONCRETE MIXTURES AS A FUNCTION OF AGE AT THREE LEUELS OF WATER REDUCTION. PLOT SUGGESTS LOGARITHMIC RELATIONSHIP OF STRENGTH AND AGE. 
Table A8

Table of Correlation Coefficients

for Strength Vs Ln(days)

\begin{tabular}{lcccc}
\hline Type of WRA & $\begin{array}{c}\text { Pozzolan } \\
\text { Replacement } \\
\text { (percent) }\end{array}$ & $\begin{array}{c}\text { Temperature } \\
\text { F }\end{array}$ & $\begin{array}{c}\text { Correlation } \\
\text { Nonefficient }\end{array}$ \\
\cline { 2 - 3 } None & 0 & 73 & 0.9715 \\
None & 0 & 122 & 0.9546 \\
None & 20 & 73 & 0.9826 \\
None & 20 & 122 & 0.8867 \\
None & 35 & 73 & 0.9922 \\
None & 35 & 122 & 0.8606 \\
None & 50 & 73 & 0.9916 \\
Conventional & 50 & 122 & 0.8687 \\
Conventional & 0 & 73 & 0.9750 \\
Conventional & 0 & 122 & 0.8890 \\
Conventional & 20 & 73 & 0.9933 \\
Conventional & 20 & 122 & 0.9193 \\
Conventional & 35 & 73 & 0.9869 \\
Conventional & 35 & 122 & 0.98008 \\
Conventional & 50 & 73 & 0.8578 \\
High-Range & 50 & 122 & 0.9956 \\
High-Range & 0 & 73 & 0.9711 \\
High-Range & 0 & 122 & 0.9936 \\
High-Range & 20 & 73 & 0.8779 \\
High-Range & 20 & 122 & 0.8839 \\
High-Range & 35 & 73 & 0.9853 \\
High-Range & 35 & 73 & 0.8863 \\
High-Range & 50 & 122 & \\
\hline & 50 & & \\
\hline
\end{tabular}

\section{Summary}

16. The analysis of these data indicates that concrete mixtures with high-range WRA produced material which had significantly larger compressive strengths at all ages which were evaluated. Furthermore, within all WRA treatments the introduction of pozzolan replacement tended to reduce the compressive strength. As far as curing temperature is concerned, concrete cured at $122^{\circ} \mathrm{F}$ initially was stronger. However, 
by 90 -days age, this concrete possessed significantly lower strength than the concrete cured at $73^{\circ} \mathrm{F}$.

17. The analysis also indicated that for $73^{\circ} \mathrm{F}$ curing temperature at ages greater than 28 days that no significant difference was seen in compressive strengths at pozzolan replacements up to 35 percent when no WRA and conventional WRA are used. However, the range of pozzolan replacement up to which no significant difference in compressive strength was observed was only 20 percent with high-range WRA at the $73^{\circ} \mathrm{F}$ curing temperature. At a curing temperature of $122^{\circ} \mathrm{F}$, the situation was the same except that for high-range WRA significant difference (reduction) in compressive strength occurred at all levels of pozzolan replacement over 0 percent and significant difference was seen in compressive strengths with no WRA at pozzolan replacements greater than 20 percent.

18. Also, compressive strengths tend to be logarithmically associated with age. This relation is substantiated with the correlation coefficients as shown in Table A8. As is seen from this table, all correlation coefficients are very close to 1.00 with the smallest being 0.8289 and the largest being 0.9956 . 
APPENDIX B: EXPERIMENT II, EVALUATIONS OF COMPRESSIVE STRENGTH GAINS OF PHASE I CONCRETE MIXTURES BY AGE WITH RESPECT TO VARYING SOLID VOLUMES OF CEMENTITIOUS MATERIALS, CURING METHOD, CURING TEMPERATURE, AND POZZOLAN REPLACEMENT

\section{Experimental Design}

1. The scope of this experiment was to evaluate four independent variables or factors which potentially affect compressive strength. The four variables or factors were curing method (sealed or immersed), curing temperature $\left(73^{\circ} \mathrm{F}\right.$ or $\left.122^{\circ} \mathrm{F}\right)$, solid volumes of cementitious material per cubic yard ( 3.347 or $\left.4.782 \mathrm{ft}^{3} / \mathrm{yd}^{3} *\right)$, and percent pozzolan replacement ( 0 or 35 percent). The data used in this experiment were from mixtures No. 13, 15, 20, and 21. The compressive strengths from these mixtures at curing ages of 3 days, 7 days, 28 days, 90 days, and 365 days were analyzed using a $2^{4}$ factorial model, that is a four factor factorial with two levels per factor. To insure statistical reliability, each of the 16 different treatment combinations was repeated 3 times.

2. The analysis of variance along with the significant effects for this experiment will be discussed by age. At each age, the analysis of variance will be composed of factor combinations in Table B1 which will affect compressive strength.

\section{Age $=3$ Days: Analysis and Interpretation}

3. After 3 days of curing, the analysis of variance indicated that the following effects were significant: curing temperature $(\mathrm{F}=$ 195.98, $\mathrm{P}=0.0001$ ), curing method by temperature interaction effect $(\mathrm{F}=7.27, \mathrm{P}=0.0111)$, amount of cement per cubic yard $(\mathrm{F}=368.97, \mathrm{P}=$ $0.0001)$, and percent pozzolan replacement $(F=1061.6, P=0.0001)$. The F value within each set of parentheses represents a calculated F-ratio, that is the ratio of the particular treatment mean squares to the experimental error. The P-value represents the actual significance level of

* Cementitious materials contents by solid volume equivalent to seven and ten 94-1b bags, respectively. 
Table B1

Analysis of Variance

\section{Source of Variation}

Curing Method

Curing Temperature

Method by Temperature Interaction

Amount of Cement/Cubic Yard

Method of Amount Interaction

Temperature by Amount Interaction

Method by Temperature by Amount Interaction

Percent Pozzolan Replacement

Method by Pozzolan

Temperature by Pozzolan

Method by Temperature by Pozzolan

Amount by Pozzolan

Method by Amount by Pozzolan

Temperature by Amount by Pozzolan

Method by Temperature by Amount by Pozzolan

Experimental Error
Degrees of Freedom

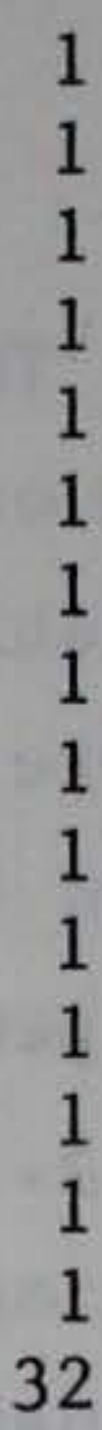

the test, that is the probability of finding an F-value which is larger than the calculated F-ratio. $\mathrm{P}<.05$ is interpreted as significant.

4. Ancillary to the analysis of variance and using Duncan's Multiple Range Test, it is found that at 3 -days age curing at $122^{\circ} \mathrm{F}$ yielded a compressive strength of 5596 psi, whereas curing at $73^{\circ}$ yielded a significantly lower compressive strength of 4417 psi. Also, concrete containing a $\mathrm{CM}=4.782 \mathrm{ft}^{3} / \mathrm{yd}^{3}$ exhibited a significantly larger compressive strength than concrete containing a $\mathrm{CM}=3.347 \mathrm{ft}^{3} / \mathrm{yd}^{3}$ (5816 psi to $4197 \mathrm{psi})$. Likewise, concrete which had a 0 percent pozzolan replacement exhibited significantly higher compressive strengths than concrete with 35 percent pozzolan replacement (6379 psi to 3634 ). When considering the curing method by temperature interaction in Table B2, it is readily seen that the $122^{\circ} \mathrm{F}$ curing temperature exhibited numerically higher compressive strengths than the $73^{\circ} \mathrm{F}$ curing temperature. Furthermore, the increase in compressive strengths of specimens cured sealed at $73^{\circ} \mathrm{F}$ to sealed at $122^{\circ} \mathrm{F}$ is significantly larger than the increase exhibited by the immersed curing method. 
Table B2

Average Compressive Strength (psi) at 3 Days for

Curing Method by Curing Temperature $(n=12)$

\begin{tabular}{llcc} 
Curing Method & \multicolumn{2}{c}{ Curing Temperature } \\
\cline { 2 - 3 } Sealed & $\frac{73^{\circ} \mathrm{F}}{4309}$ & $\frac{122^{\circ} \mathrm{F}}{5716}$ & Difference \\
Immersed & 4524 & 5477 & $-1407 *$ \\
& Absolute Difference & $-953 *$ \\
\hline
\end{tabular}

* Indicates significance at .05 level of significance. Critical value for difference is -243 psi.

** Indicates significance at .05 level of significance. Critical value for absolute difference is 344 psi.

\section{Age $=7$ Days: Analysis and Interpretation}

5. After 7 days, the analysis of variance indicated that the following effects were significant: curing temperature $(\mathrm{F}=118.20, \mathrm{P}=$ $0.0001)$, amount of cement per cubic yard $(F=153.51, P=0.0001)$, percent pozzolan replacement $(F=289.05, P=0.0001)$, the curing temperature by percent pozzolan replacement interaction $(\mathrm{F}=23.68, \mathrm{P}=0.0001)$, and third-order interaction team of curing method by amount of cement by percent pozzolan replacement $(F=4.42, P=0.0435)$. With the significan main effects, Duncan's Multiple Range Test indicated that curing at $122^{\circ} \mathrm{F}$ yielded a significantly higher mean compressive strength ( 7171 psi) than curing at $73^{\circ} \mathrm{F}$ (5761 psi); concrete with a $\mathrm{CM}=4.782 \mathrm{ft}^{3} / \mathrm{yd}^{3}$ exhibited a significantly higher mean compressive strength value (7269 psi) than concrete with a $\mathrm{CM}=3.347 \mathrm{ft}^{3} / \mathrm{yd}^{3}$ (5663 psi); and that concrete with 0 percent pozzolan replacement exhibited significantly higher compressive strength (7568 psi) than concrete with 35 percent pozzolan replacement (5364 psi).

6. Furthermore, when considering the two significant interaction terms, the following can be concluded: From Table B3, it is seen that the difference in compressive strength between 0 - and 35-percent pozzolan replacement for concrete cured at $73^{\circ} \mathrm{F}$ is significantly higher than the 
Table B3

Average Compressive Strength (psi) at 7 Days for

Curing Temperature by Percent Pozzolan Replacement $(n=12)$

Curing Temperature

$73^{\circ} \mathrm{F}$

$122^{\circ} \mathrm{F}$

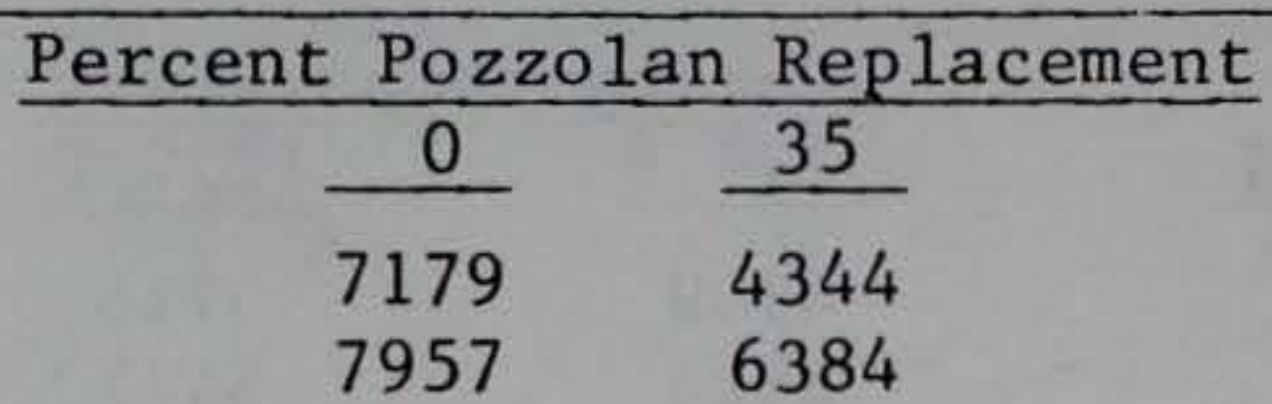

Absolute Difference
Difference

$2935 *$

$1573 *$

$1362 * *$

* Indicates significance at .05 level of significance. Critical value for difference is 374 psi.

** Indicates significance at .05 level of significance. Critical value for difference is 528 psi.

observed difference in compressive strength for concrete cured at $122^{\circ} \mathrm{F}$ (absolute difference of 1362 is larger than critical absolute difference of 528 psi). Also, it is seen (Table B4) that this difference only applies to a $C M=4.782 \mathrm{ft}^{3} / \mathrm{yd}^{3}$ where the sealed method of curing displayed the largest reduced compressive strength gain between 0- and 35percent pozzolan replacement levels.

Table B4

Average Compressive Strength (psi) at 7 Days for

Cementitious Material Content by Curing Method and Pozzolan Replacement $(\mathrm{n}=6)$

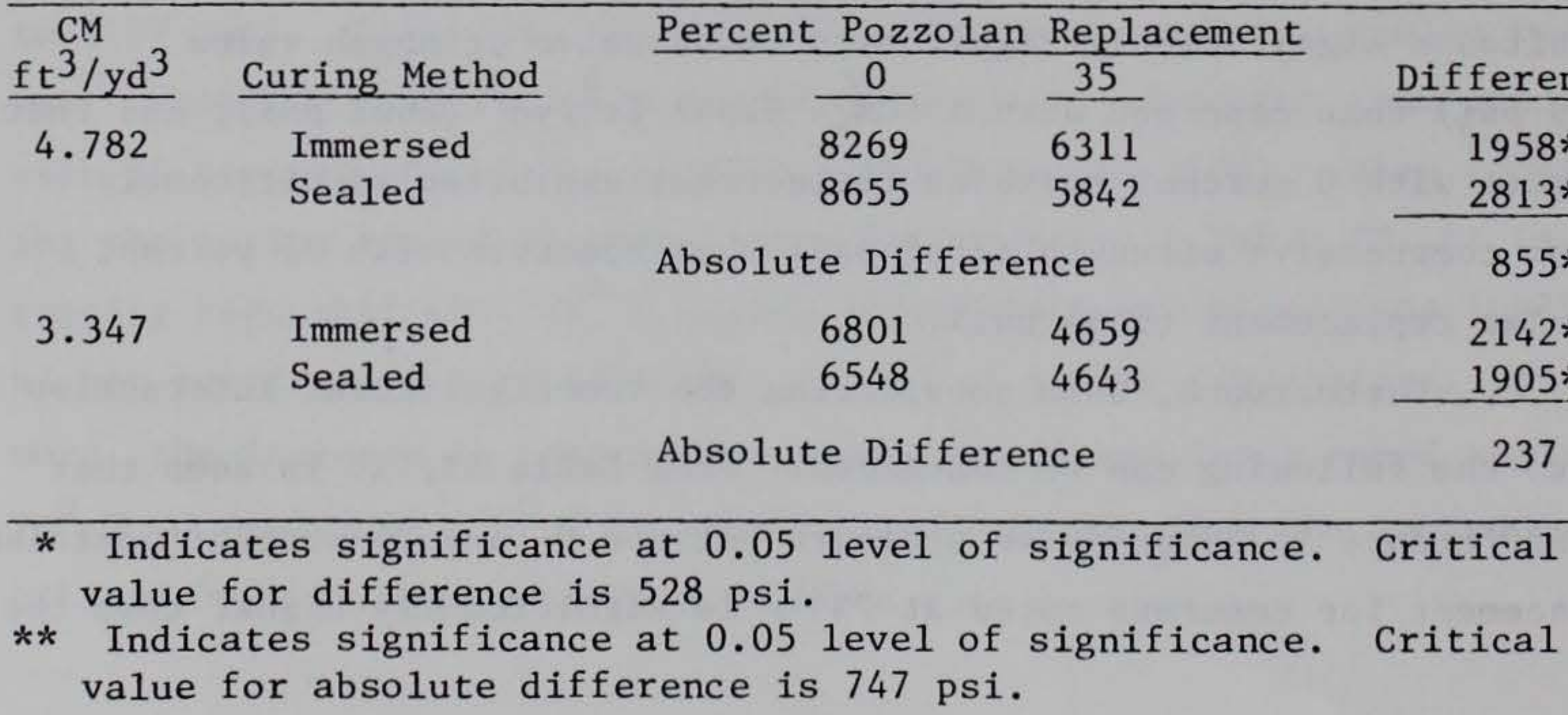




\section{Age $=28$ Days: Analysis and Interpretation}

7. After 28 days, the analysis of variance procedure exhibited the following significant differences: curing method $(\mathrm{F}=36.28, \mathrm{P}=$ $0.0001)$, curing temperature $(F=52.94, P=0.0001)$, amount of cement $(\mathrm{F}=206.07, \mathrm{P}=0.0001)$, percent pozzolan replacement $(\mathrm{F}=280.29, \mathrm{P}=$ $0.0001)$, and amount of cement by percent pozzolan replacement $(F=10.69$, $\mathrm{P}=0.0026)$. Ancillary to the analysis of variance procedure, Duncan's Multiple Range Test indicates that immersed curing exhibited significantly higher compressive strength than did the sealed curing method (8474 psi as compared to $7765 \mathrm{psi}$, respectively); curing at $122^{\circ} \mathrm{F}$ exhibited significantly higher compressive strength than curing at $73^{\circ} \mathrm{F}$ (8548 psi as compared to 7691 psi, respectively); mixtures composed of a $\mathrm{CM}=$ $4.782 \mathrm{ft}^{3} / \mathrm{yd}^{3}$ exhibited significantly higher compressive strength than mixtures composed of a $\mathrm{CM}=3.347 \mathrm{ft}^{3} / \mathrm{yd}^{3}$ (8965 psi as compared to 7275 psi, respectively); and concrete material with 0 percent pozzolan replacement exhibited significantly higher compressive material than concrete material with 35 percent pozzolan replacement (9105 psi as compared to $7134 \mathrm{psi}$, respectively). Furthermore, when considering cementitious materials content by percent pozzolan replacement, it is readily seen that concrete with a $C M=4.782 \mathrm{ft}^{3} / \mathrm{yd}^{3}$ material exhibited higher compressive strength as percent pozzolan replacement decreased (Table B5); whereas concrete with a $C M=3.347 \mathrm{ft}^{3} / \mathrm{yd}^{3}$ exhibited a similar trend. The increase in compressive strength was approximately 60 percent of that observed with concrete with a $C M=4.782 \mathrm{ft}^{3} / \mathrm{yd}^{3}$.

8. Not only is there a significant increase in compressive strength as percent pozzolan replacement decreases, but also the rate of increase for concrete cured at $122^{\circ} \mathrm{F}$ was significantly larger than the rate of increase for concrete cured at $73^{\circ} \mathrm{F}$ (Table B6).

9. As with curing temperature and percent pozzolan replacement, an increase in percent pozzolan replacement dictates significantly lower compressive strength (Table B7) for each level of cementitious material content. Furthermore, concrete with a $C M=4.782 \mathrm{ft}^{3} / \mathrm{yd}^{3}$ exhibited significantly larger reduced compressive strength gain than concrete 
Table B5

Average Compressive Strength (psi) at 28 Days for

Cementitious Material Content by Pozzolan Replacement $(n=12)$

\begin{tabular}{cccc}
\hline CM & Percent Pozzolan Replacement & \\
\cline { 2 - 2 } $\mathrm{ft}^{3} / \mathrm{yd}^{3}$ & $\frac{0}{10,143}$ & $\frac{35}{7787}$ & Difference \\
\hline 4.782 & 8,068 & 6481 & $2356^{*}$ \\
3.347 & Absolute Difference & $1587^{*}$ \\
& & & 769 \\
\hline
\end{tabular}

\footnotetext{
* Indicates significance at 0.05 level of significance. Critical value for difference is 339 psi.

** Indicates significance at 0.05 level of significance. Critical value for absolute difference is $480 \mathrm{psi}$.
}

Table B6

Average Compressive Strength (psi) at 28 Days for

Curing Temperature by Pozzolan Replacement $(\mathrm{n}=12)$

\begin{tabular}{cccc}
\hline \multirow{2}{*}{ Curing Temperature } & \multicolumn{2}{c}{ Percent Pozzolan Replacement } & Difference \\
\cline { 2 - 4 } & $\frac{0}{73^{\circ} \mathrm{F}}$ & $\frac{35}{8416}$ & \\
$122^{\circ} \mathrm{F}$ & 9,776 & 8416 & $1360^{*}$ \\
& 10,367 & 7874 & $2493^{*}$ \\
\hline & Absolute Difference & $1173^{* *}$
\end{tabular}

* Indicates significance at 0.05 level of significance. Critical value for difference is 339 psi.

** Indicates significance at 0.05 level of significance. Critical value for absolute difference is $480 \mathrm{psi}$. 
Table B7

Average Compressive Strength (psi) at 28 Days for

Cementitious Material Content by Pozzolan Replacement $(n=12)$

$\mathrm{ft} \mathrm{t}^{3} / \mathrm{yd}^{3}$

4.782

3.347

$\frac{\text { Percent Pozzolan }}{\text { Replacement }}$

Absolute Difference
Difference

2398*

$1455^{*}$

$943 * *$

* Indicates significance at 0.05 level of significance. Critical value for difference is 339 psi.

** Indicates significance at 0.05 level of significance. Critical value for absolute critical difference is 480 psi.

with a $\mathrm{CM}=3.347 \mathrm{ft}^{3} / \mathrm{yd}^{3}$. Likewise, the change in compressive strength between 0- and 35-percent pozzolan replacement was significantly larger for concrete with a $\mathrm{CM}=4.782 \mathrm{ft}^{3} / \mathrm{yd}^{3}$ than concrete with a $\mathrm{CM}=$ $3.347 \mathrm{ft}^{3} / \mathrm{yd}^{3}$.

\section{$\underline{\text { Age }=90 \text { Days: Analysis and Interpretation }}$}

10. After 90 days, the analysis of variance exhibited the following significant effects: curing method $(F=54.23, P=0.0001)$, CM content $(F=188.88, P=0.0001)$, curing temperature by CM content interaction $(F=8.76, P=0.005)$, percent pozzolan replacement $(F=276.81$, $\mathrm{P}=0.0001)$, curing temperature by percent pozzolan replacement interaction $(F=23.91, P=0.0001)$, and $C M$ content by percent pozzolan replacement interaction $(F=16.58, P=0.0003)$. When considering the effects individually, Duncan's Multiple Range Test indicates that immersed cured concrete exhibits significantly higher compressive strength (9535 psi) than concrete cured under seal (8672 psi); concrete composed of a $\mathrm{CM}=$ $4.782 \mathrm{ft}^{3} / \mathrm{yd}^{3}$ exhibited significantly higher compressive strength material (9904 psi) than concrete composed of a $\mathrm{CM}=3.347 \mathrm{ft}^{3} / \mathrm{yd}^{3}$ (8312 $\left.\mathrm{psi}\right)$; and that concrete with 0 percent pozzolan replacement exhibited significantly higher compressive strength $(10,072$ psi) than concrete with 35 percent pozzolan replacement (8145 psi). 
11. Furthermore, when considering the three significant interaction terms, the following can be concluded. From Table B8, it is seen that concrete with a $\mathrm{CM}=4.782 \mathrm{ft}^{3} / \mathrm{yd}^{3}$ cured at $122^{\circ} \mathrm{F}$ exhibited a significantly higher compressive strength gain than the same concrete cured at $73^{\circ} \mathrm{F}$. This trend was not observed for concrete with a $\mathrm{CM}=$ $3.347 \mathrm{ft}^{3} / \mathrm{yd}^{3}$.

\section{Table B8}

Average Compressive Strength (psi) at 90 Days for Cementitious Material Content by Curing Temperature $(n=12)$

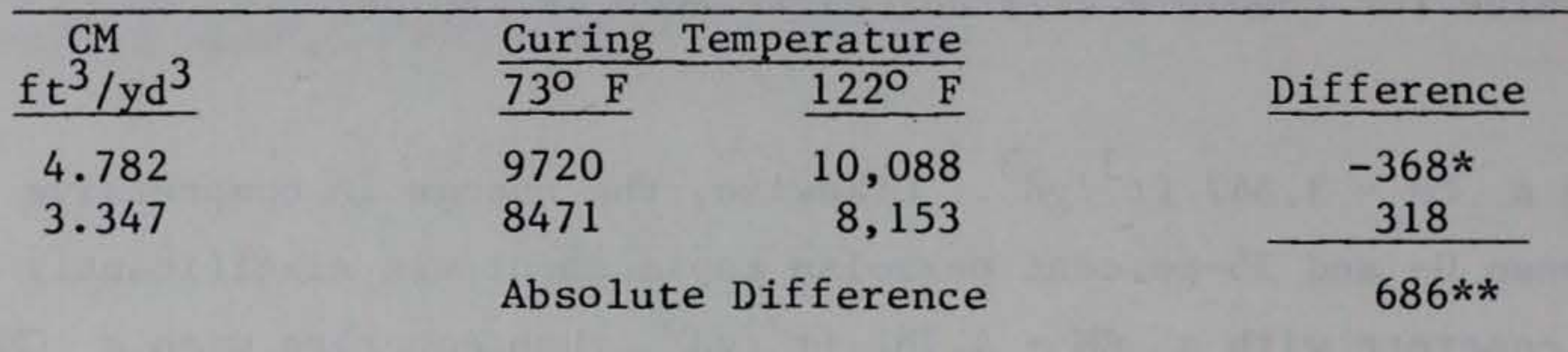

* Indicates significance at 0.05 level of significance. Critical value for difference is $+334 \mathrm{psi}$.

** Indicates significance at 0.05 level of significance. Critical value for absolute difference is 472 psi.

\section{Age $=365$ Days: Analysis and Interpretation}

12. After 365 days, the analysis of variance procedure exhibited the following significant effects: curing method $(F=22.47, P=0.0001)$; curing temperature $(F=51.36, P=0.0001) ; C M$ content $(F=60.40, P=$ $0.0001)$; percent pozzolan replacement $(\mathrm{F}=172.48, \mathrm{P}=0.0001)$; curing method by percent pozzolan replacement $(F=9.91, P=0.0036)$; and curing temperature by percent pozzolan replacement $(F=21.60, P=0.0001)$. When considering the significant effects individually, Duncan's Multiple Range Test indicates that immersed cured concrete exhibited significantly larger compressive strength $(10,430 \mathrm{psi})$ than concrete cured under seal $\left(9,639\right.$ psi); curing at $73^{\circ} \mathrm{F}$ exhibited material with significantly higher compressive strength $(10,632)$ than concrete cured at $122^{\circ} \mathrm{F}(9,436$ psi); concrete composed of a $\mathrm{CM}=.4 .782 \mathrm{ft}^{3} / \mathrm{yd}^{3}$ exhibited significantly 
higher compressive strength $(10,682 \mathrm{psi})$ than concrete composed of a $\mathrm{CM}=3.347 \mathrm{ft}^{3} / \mathrm{yd}^{3}(9,386 \mathrm{psi})$; and concrete with 0 percent pozzolan replacement exhibited significantly larger compressive strength material $(11,129$ psi) than material with 35 percent pozzolan replacement $(8,939$ psi).

13. Furthermore, when considering the two significant interaction terms, the following can be concluded. As can be seen from Table B9, not only does increased percent pozzolan replacement decrease compressive strength, but also concrete cured under sealed conditions displayed a significantly higher increase than material cured by immersion.

Table B9

Average Compressive Strength (psi) at 365 Days for

Curing Method by Pozzolan Replacement $(n=12)$

\begin{tabular}{lccc}
\hline & \multicolumn{2}{c}{ Percent Pozzolan Replacement } & Difference \\
\cline { 2 - 4 } Curing Method & 0 & $\frac{35}{9567}$ & $\frac{1695 *}{11,262}$ \\
Immersed & 10,997 & 8280 & $2717 *$ \\
Sealed & Absolute Difference & $1022 * *$
\end{tabular}

* Indicates significance at 0.05 level of significance. Critical value of difference is 481 psi.

** Indicates significance at 0.05 level of significance. Critical value of difference is 680 psi.

14. From Table B10, it is readily seen that increased percent pozzolan replacement decreases compressive strengths. Also, concrete cured at $122^{\circ} \mathrm{F}$ displayed a significantly lower strength gain as percent pozzolan increased than material cured at $73^{\circ} \mathrm{F}$.

\section{Summary}

15. Throughout the investigation to ages of 1 year concrete composed of a $\mathrm{CM}=4.782 \mathrm{ft}^{3} / \mathrm{yd}^{3}$ exhibited significantly higher compressive strengths than concrete composed of a $C M=3.347 \mathrm{ft}^{3} / \mathrm{yd}^{3}$. Also, beginning at 7 days and lasting through 365 days, concrete cured by 
Table B10

Average Compressive Strength (psi) at 365 Days for

Curing Temperature by Pozzolan Replacement ( $\mathrm{n}=12)$

\begin{tabular}{cccc}
\hline Curing Temperature & \multicolumn{2}{c}{ Percent Pozzolan Replacement } & Difference \\
\cline { 2 - 4 } $73^{\circ} \mathrm{F}$ & $\frac{0}{11,340}$ & $\frac{35}{9924}$ & $\frac{1416^{*}}{122^{\circ} \mathrm{F}}$ \\
& 10,919 & 7953 & $2966^{*}$ \\
\hline & Absolute Difference & $1550^{* *}$
\end{tabular}

\footnotetext{
* Indicates significance at 0.05 level of significance. Critical value for difference is 481 psi.

** Indicates significance at 0.051 evel of significance. Critical value for absolute difference is 680 psi.
}

immersion exhibited significantly higher compressive streng th than concrete cured under sealed conditions. Furthermore, concrete cured at $122^{\circ} \mathrm{F}$ exhibited significantly higher compressive strength than concrete cured at $73^{\circ} \mathrm{F}$ for the age periods of $3,7,28$, and 90 days; however, by 365 days, the concrete cured at $73^{\circ} \mathrm{F}$ exhibited the significantly higher compressive strength. Also, consistently through ages to 1 year, concrete with 0 percent pozzolan replacement exhibited significantly higher compressive strength than concrete with 35 percent pozzolan replacement.

16. In summary, regardless of the cementitious materials content, if larger compressive strengths are desired at the outset, then concrete should be cured at $122^{\circ} \mathrm{F}$ and immersed with 0 percent pozzolan replacement. However, if larger compressive strengths are desired at the latter ages, concrete should be cured at $73^{\circ} \mathrm{F}$ and immersed with 0 percent pozzolan replacement. 
APPENDIX C: EXPERIMENT III, MATHEMATICAL MODELING OF COMPRESSIVE STRENGTH GAINS OF PHASE I CONCRETE MIXTURES WITH RESPECT TO WATER/CEMENTITIOUS MATERIALS RATIO (W/C), SOLID VOLUMES OF CEMENTITIOUS MATERIALS (CM) CONTENT, AND AGE

\section{$\underline{\text { Introduction }}$}

1. An objective of this experiment was to model compressive strength gains with age. An initial synthesis (Appendix A) of these data indicated that compressive strength gains could be characterized by the linear model

$$
f_{c}^{\prime}=a+b \ln (\text { age })
$$

where age is measured in days, $1 \mathrm{n}$ is the natural logarithm, a is the initial 1-day compressive strength value, and $b$ is the growth rate of compressive strength through time.

2. In order to obtain estimates of the unknown modeling parameters $\mathrm{a}$ and $\mathrm{b}$, the method of least squares was utilized. The least squares method utilized observed compressive strength values $\left(f_{c}^{\prime}\right)$ at known abscissa points (ages) and minimized the residual sum of squares. The estimates of the parameters $a$ and $b$ which minimize the residual sum of squares are:

$$
\begin{aligned}
& b=\frac{\sum_{i=1}^{n}\left(x_{i}-\bar{x}\right)\left(y_{i}-\bar{y}\right)}{\sum_{i=1}^{n}\left(x_{i}-\bar{x}\right)^{2}} \\
& a=\bar{y}-b \bar{x}
\end{aligned}
$$

where $\left\{\left(x_{i}, y_{i}\right): i=1, n\right\}$ is a set of ordered pairs, $\bar{x}$ is the average of the abscissa points (age), and $\bar{y}$ is the average of the dependent variable y $\left(f_{c}^{\prime}\right)$. 
3. To investigate the compressive strength relationship through time, the following mixtures were independently used by curing method and temperature: mixtures No. $1,2,3,4,5,6,7,8,9,10,13,14,15$, $16,17,18,23 \mathrm{~A}, 19,20,21,22,26$, and 27 . These mixtures represented a wide range of cementitious materials content, pozzolan replacement, curing temperatures, and curing methods as well as a range of waterreducing admixtures.

4. Table $\mathrm{Cl}$ displays the estimates of the two regression parameters $a$ and $b$, and also two important statistical estimates, i.e., the coefficient of determination, $\mathrm{R}^{2}$, which measures the percentage of the total variance which is explained by the estimated regression model

$$
\mathrm{R}^{2}=\frac{\sum\left(\hat{\mathrm{y}}_{i}-\overline{\mathrm{y}}_{\mathrm{i}}\right)^{2}}{\sum\left(\mathrm{y}_{i}-\bar{y}\right)^{2}}
$$

where $\hat{y}_{i}$ is the predicted value of $y_{i}$ when $x$ is equal to $x_{i}$; and the estimate of the sample standard deviation is

$$
s=\sqrt{\frac{\sum\left(y_{i}-\hat{y}_{i}\right)^{2}}{n-2}}
$$

where $\mathrm{n}$ is the number of observations.

5. As can be seen from Table $\mathrm{Cl}$, the $\mathrm{R}^{2}$ values ranged from 53.23 percent to 98.86 percent. Of the individual mixtures $32 R^{2} \geq$ 90 percent, $6 \mathrm{R}^{2} \geq 80$ percent but $<90$ percent, $19 \mathrm{R}^{2}$ values $\geq 70$ percent but $<80$ percent, and $3 \mathrm{R}^{2}$ values $\geq 50$ percent but $<70$ percent. Since mathematically $R^{2}$ is the square of the linear correlation coefficient, this implies that the correlation coefficients range from 0.73 to 0.99 . As can be readily seen, this model fits the observed compressive strength data extremely well during the 2-year investigation.

6. Also, it can be seen from Tables $\mathrm{C} 2$ and $\mathrm{C} 3$ that increasing the percent pozzolan replacement tends to decrease the initial 1-day compressive strengths ( $y$ intercept value a in equation $\mathrm{C} 1$ ); whereas, increasing the curing temperature tends to increase the initial compressive 
Table Cl

Compressive Strength Versus Age Modeling

$$
\underline{f_{c}^{\prime}=a+b \log _{c} \text { (age) }}
$$

\begin{tabular}{|c|c|c|c|c|c|c|}
\hline Mixture & $\begin{array}{l}\text { Curing } \\
\text { Method }\end{array}$ & $\begin{array}{c}\text { Curing } \\
\text { Temperature }\end{array}$ & $\hat{a}^{*}$ & $\hat{b} * *$ & $\mathrm{R}^{2}+$ & stt \\
\hline \multirow[t]{2}{*}{1} & Sealed & $73^{\circ}$ & 2513 & 857.52 & 94.06 & 433 \\
\hline & & $122^{\circ}$ & 3756 & 548.24 & 92.61 & 299 \\
\hline \multirow[t]{2}{*}{2} & & $73^{\circ}$ & 1433 & 1085.51 & 95.46 & 490 \\
\hline & & $122^{\circ}$ & 3128 & 599.08 & 77.39 & 624 \\
\hline \multirow[t]{2}{*}{3} & & $73^{\circ}$ & $320 \ddagger$ & 1216.65 & 97.69 & 388 \\
\hline & & $122^{\circ}$ & 2381 & 616.96 & 74.06 & 704 \\
\hline \multirow[t]{2}{*}{4} & & $73^{\circ}$ & $-245 \ddagger$ & 1028.22 & 98.39 & 272 \\
\hline & & $122^{\circ}$ & 1577 & 551.97 & 75.20 & 611 \\
\hline \multirow[t]{2}{*}{5} & & $73^{\circ}$ & 2488 & 1024.42 & 95.55 & 463 \\
\hline & & $122^{\circ}$ & 4163 & 591.32 & 78.66 & 594 \\
\hline \multirow[t]{2}{*}{6} & & $73^{\circ}$ & 1484 & 1159.19 & 98.00 & 347 \\
\hline & & $122^{\circ}$ & 3176 & 683.59 & 84.51 & 564 \\
\hline \multirow[t]{2}{*}{7} & & $73^{\circ}$ & 597 & 1346.76 & 97.43 & 460 \\
\hline & & $122^{\circ}$ & 3122 & 625.41 & 74.02 & 779 \\
\hline \multirow[t]{2}{*}{8} & & $73^{\circ}$ & $-154 \ddagger$ & 1202.48 & 96.51 & 479 \\
\hline & & $122^{\circ}$ & 1801 & 701.73 & 74.79 & 785 \\
\hline \multirow[t]{2}{*}{9} & & $73^{\circ}$ & 1955 & 1393.36 & 94.33 & 658 \\
\hline & & $122^{\circ}$ & 4322 & 727.93 & 74.79 & 814 \\
\hline \multirow[t]{2}{*}{10} & & $73^{\circ}$ & 1721 & 1571.04 & 98.33 & 412 \\
\hline & & $122^{\circ}$ & 4744 & 743.07 & 77.64 & 769 \\
\hline \multirow[t]{2}{*}{13} & & $73^{\circ}$ & 3823 & 1053.12 & 95.99 & 453 \\
\hline & & $122^{\circ}$ & 5459 & 764.09 & 81.60 & 763 \\
\hline \multirow[t]{2}{*}{14} & & $73^{\circ}$ & 2560 & 1236.76 & 94.32 & 636 \\
\hline & & $122^{\circ}$ & 4739 & 718.62 & 77.07 & 755 \\
\hline \multirow[t]{2}{*}{15} & & $73^{\circ}$ & 1412 & 1193.31 & 95.57 & 541 \\
\hline & & $122^{\circ}$ & 4307 & 420.27 & 53.23 & 829 \\
\hline \multirow[t]{2}{*}{16} & & $73^{\circ}$ & 743 & 1166.21 & 95.74 & 515 \\
\hline & & $122^{\circ}$ & 2605 & 650.93 & 78.55 & 656 \\
\hline
\end{tabular}

(Continued) 
Table Cl (Continued)

\begin{tabular}{|c|c|c|c|c|c|c|}
\hline Mixture & $\begin{array}{l}\text { Curing } \\
\text { Method }\end{array}$ & $\begin{array}{c}\text { Curing } \\
\text { Temperature }\end{array}$ & $\hat{a}^{*}$ & $\hat{b}^{* *}$ & $\mathrm{R}^{2}+$ & $\underline{s t t}$ \\
\hline \multirow[t]{2}{*}{17} & Sealed & $73^{\circ}$ & 4831 & 1078.24 & 94.82 & 485 \\
\hline & & $122^{\circ}$ & 6245 & 826.04 & 91.21 & 494 \\
\hline \multirow[t]{2}{*}{18} & & $73^{\circ}$ & 2944 & 1060.41 & 94.76 & 525 \\
\hline & & $122^{\circ}$ & 5571 & 403.91 & 59.89 & 695 \\
\hline \multirow[t]{2}{*}{19} & & $73^{\circ}$ & 1791 & 1159.74 & 93.05 & 664 \\
\hline & & $122^{\circ}$ & 4025 & 610.81 & 71.21 & 749 \\
\hline \multirow[t]{2}{*}{20} & & $73^{\circ}$ & 5647 & 1076.17 & 93.02 & 546 \\
\hline & & $122^{\circ}$ & 7708 & 659.83 & 76.35 & 680 \\
\hline \multirow[t]{2}{*}{21} & & $73^{\circ}$ & 2242 & 1321.53 & 96.38 & 474 \\
\hline & & $122^{\circ}$ & 5300 & 592.06 & 66.05 & 786 \\
\hline \multirow[t]{2}{*}{22} & & $73^{\circ}$ & 1242 & 1486.35 & 98.73 & 325 \\
\hline & & $122^{\circ}$ & 4310 & 856.26 & 88.97 & 581 \\
\hline \multirow[t]{2}{*}{23} & & $73^{\circ}$ & 2670 & 1352.50 & 96.66 & 484 \\
\hline & & $122^{\circ}$ & 5059 & 673.15 & 74.03 & 768 \\
\hline \multirow[t]{2}{*}{25} & & $73^{\circ}$ & $-160 \ddagger$ & 1226.62 & 99.03 & 234 \\
\hline & & $122^{\circ}$ & 1910 & 698.33 & 78.16 & 711 \\
\hline \multirow[t]{2}{*}{26} & & $73^{\circ}$ & 2195 & 1076.67 & 95.39 & 456 \\
\hline & & $122^{\circ}$ & 3769 & 716.61 & 82.11 & 645 \\
\hline \multirow[t]{2}{*}{27} & & $73^{\circ}$ & $219 \pm$ & 1178.42 & 98.86 & 243 \\
\hline & & $122^{\circ}$ & 2200 & 592.17 & 77.07 & 622 \\
\hline \multirow[t]{2}{*}{7} & Immersed & $73^{\circ}$ & 706 & 1328.94 & 97.23 & 472 \\
\hline & & $122^{\circ}$ & 2856 & 804.72 & 77.71 & 907 \\
\hline \multirow[t]{2}{*}{13} & & $73^{\circ}$ & 4114 & 1102.75 & 97.14 & 398 \\
\hline & & $122^{\circ}$ & 5262 & 960.64 & 96.97 & 357 \\
\hline \multirow[t]{2}{*}{15} & & $73^{\circ}$ & 1158 & 1425.52 & 93.99 & 758 \\
\hline & & $122^{\circ}$ & 3847 & 693.83 & 73.34 & 880 \\
\hline \multirow[t]{2}{*}{18} & & $73^{\circ}$ & 3188 & 1265.30 & 93.27 & 715 \\
\hline & & $122^{\circ}$ & 5385 & 679.47 & 73.53 & 836 \\
\hline \multirow[t]{2}{*}{20} & & $73^{\circ}$ & 6220 & 1036.94 & 86.28 & 766 \\
\hline & & $122^{\circ}$ & 6902 & 924.31 & 86.22 & 685 \\
\hline
\end{tabular}


Table Cl (Concluded)

\begin{tabular}{|c|c|c|c|c|c|c|}
\hline Mixture & $\begin{array}{l}\text { Curing } \\
\text { Method }\end{array}$ & $\begin{array}{c}\text { Curing } \\
\text { Temperature }\end{array}$ & $\hat{a} *$ & $\mathrm{~b} * *$ & $\mathrm{R}^{2}+$ & stt \\
\hline \multirow[t]{2}{*}{20} & Immersed & $73^{\circ}$ & 6220 & 1036.94 & 86.28 & 766 \\
\hline & & $122^{\circ}$ & 6902 & 924.31 & 86.22 & 685 \\
\hline \multirow[t]{2}{*}{21} & & $73^{\circ}$ & 2223 & 1567.97 & 94.91 & 672 \\
\hline & & $122^{\circ}$ & 4994 & 862.76 & 72.24 & 991 \\
\hline
\end{tabular}

* Estimate of compressive strength at 1 day.

** Estimate of compressive strength growth rate.

+ Coefficient of determination. The percentage of the total variance explained by the regression equation.

$+\dagger$ The standard deviation.

$\ddagger$ Not significantly different from zero. 
Table C2

Models of Compressive Strength

$$
\mathrm{f}_{\mathrm{c}}^{\prime}=\mathrm{a}+\mathrm{bx}_{1}{ }^{*}
$$

Curing Method: Sealed

\begin{tabular}{|c|c|c|c|c|c|}
\hline WRA/Temp & $0 \%$ Pozzolan & $20 \%$ Pozzolan & $35 \%$ Pozzolan & $50 \%$ Pozzolan & $\begin{array}{r}\mathrm{CM} * * \\
\mathrm{ft}^{3} / \mathrm{yd}^{3} \\
\end{array}$ \\
\hline $\begin{array}{r}\text { None } \\
73^{\circ} \mathrm{F} \\
122^{\circ} \mathrm{F}\end{array}$ & $\begin{array}{l}2513+857.52 x_{1} \\
3756+548.24 x_{1}\end{array}$ & $\begin{array}{l}1433+1085.51 x_{1} \\
3128+599.08 x_{1}\end{array}$ & $\begin{array}{l}320 *+1216.65 x_{1} \\
2381+616.96 x_{1}\end{array}$ & $\begin{array}{l}-245 *+1028.22 x_{1} \\
1577+551.97 x_{1}\end{array}$ & 3.347 \\
\hline $\begin{array}{l}\text { Conventional } \\
73^{\circ} \mathrm{F} \\
122^{\circ} \mathrm{F}\end{array}$ & $\begin{array}{l}2488+1024.42 x_{1} \\
4163+591.32 x_{1}\end{array}$ & $\begin{array}{l}1484+1159.19 x_{1} \\
3176+683.59 x_{1}\end{array}$ & $\begin{array}{l}597+1346.76 x_{1} \\
3122+625.41 x_{1}\end{array}$ & $\begin{array}{l}-154 *+1202.48 x_{1} \\
1801+701.73 x_{1}\end{array}$ & 3.347 \\
\hline $\begin{array}{l}\text { High-Range } \\
73^{\circ} \mathrm{F} \\
122^{\circ} \mathrm{F}\end{array}$ & $\begin{array}{l}3823+1053.12 x_{1} \\
5459+764.09 x_{1}\end{array}$ & $\begin{array}{l}2560+1236.76 x_{1} \\
4739+718.62 x_{1}\end{array}$ & $\begin{array}{l}1412+1193.31 x_{1} \\
4307+420.27 x_{1}\end{array}$ & $\begin{array}{l}743+1166.21 x_{1} \\
2605+650.93 x_{1}\end{array}$ & 3.347 \\
\hline $\begin{array}{l}\text { Conventional } \\
73^{\circ} \mathrm{F} \\
122^{\circ} \mathrm{F}\end{array}$ & & & $\begin{array}{l}1955+1393.36 x_{1} \\
4322+727.93 x_{1}\end{array}$ & & 4.065 \\
\hline $\begin{array}{l}\text { High-Range } \\
73^{\circ} \mathrm{F}\end{array}$ & $\begin{array}{l}4831+1078.24 x_{1} \\
6245+826.04 x_{1}\end{array}$ & (Cont & $\begin{array}{l}2944+1060.41 x_{1} \\
2670+1352.50 x_{1} \\
5571+403.91 x_{1} \\
5059+673.15 x_{1} \\
\text { ued) }\end{array}$ & $1791+1159.74 x_{1}$ & 4.065 \\
\hline
\end{tabular}


Table C2 (Concluded)

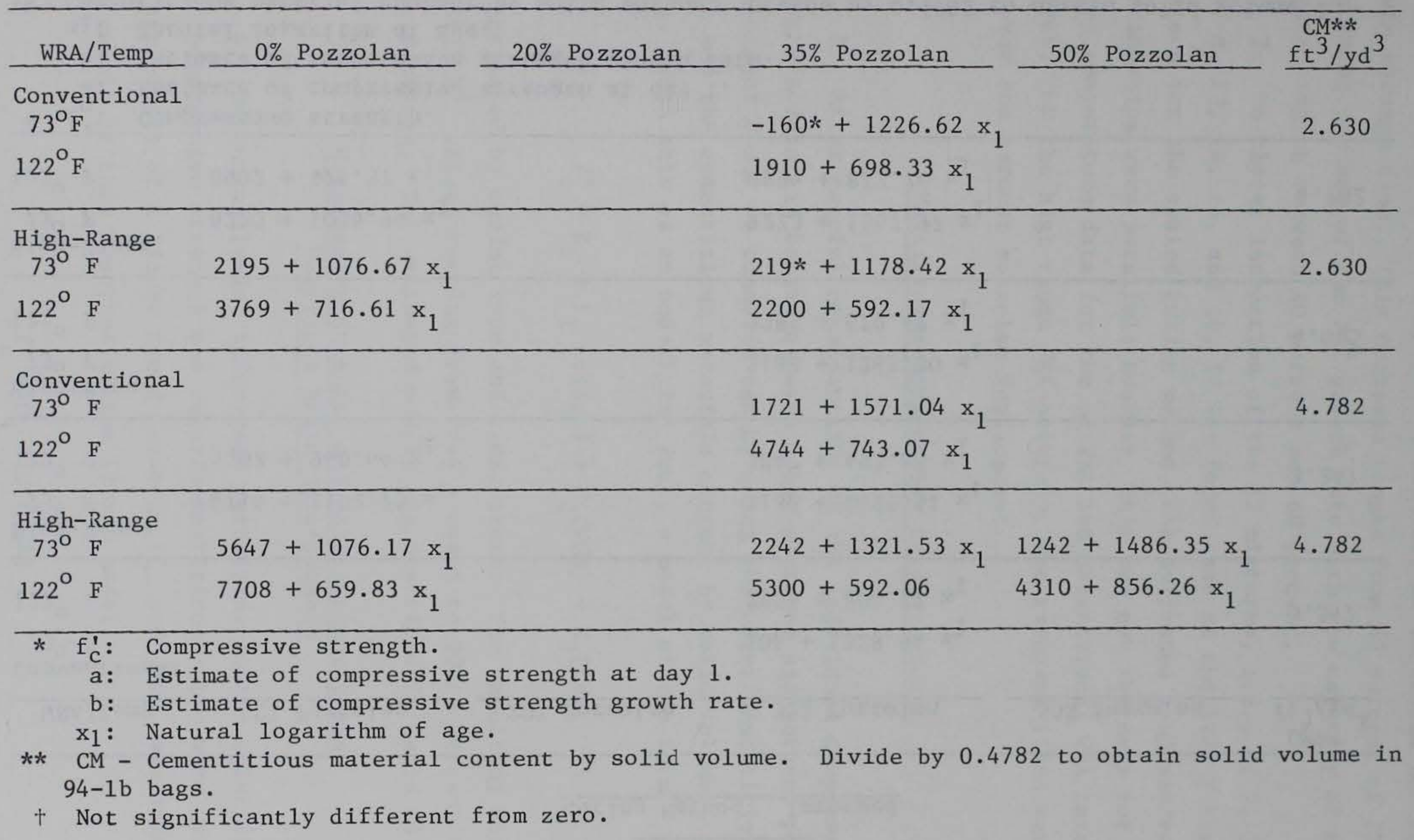


Table C3

Models of Compressive Strength

$$
\mathrm{f}_{\mathrm{c}}^{\prime}=\mathrm{a}+\mathrm{b} \mathrm{x}_{1} \text { * }
$$

Curing Method: Immersed

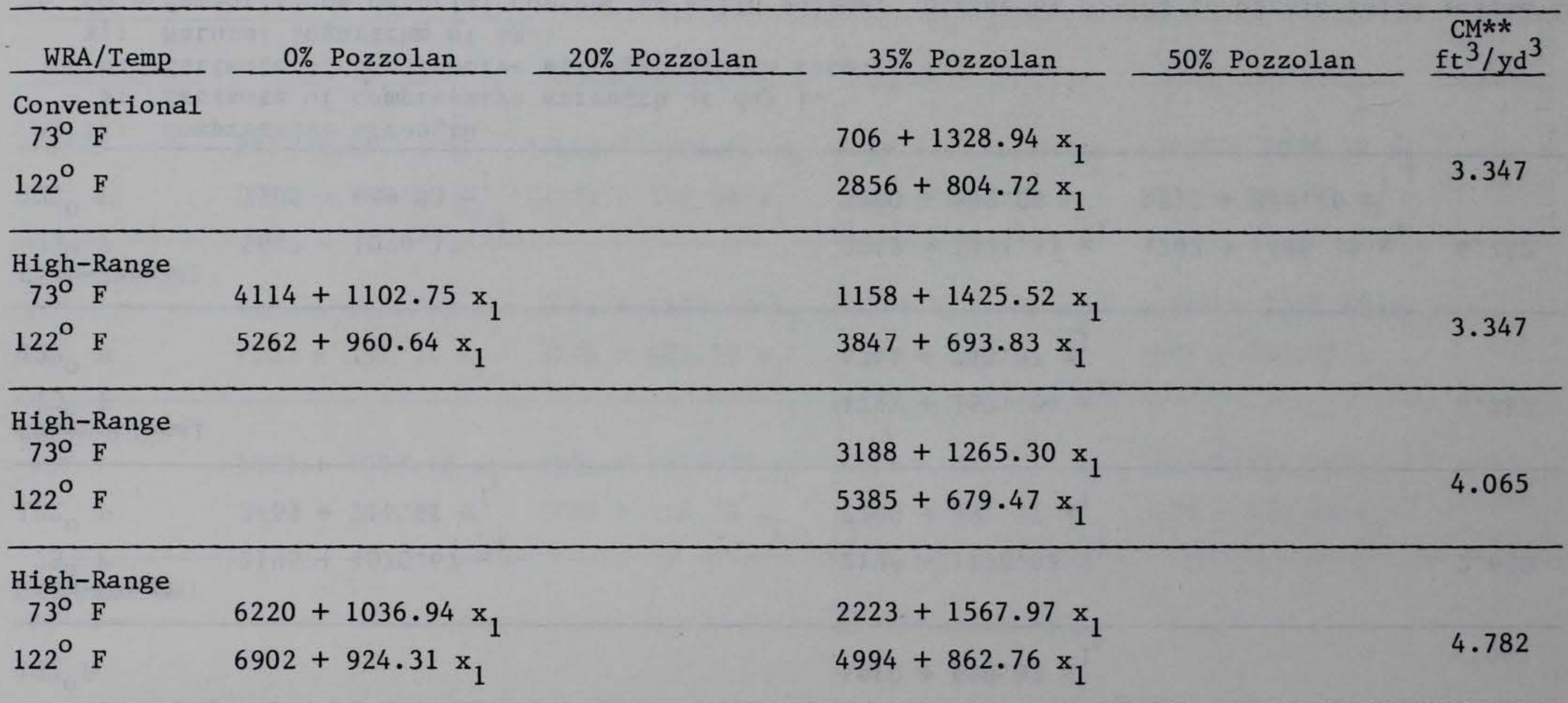

* $f_{c}^{\prime}:$ Compressive strength.

a: Estimate of compressive strength at day 1 .

b: Estimate of compressive strength growth rate.

$\mathrm{x}_{1}$ : Natural logarithm of age.

** Cementitious material content by solid volume. Divide by 0.4782 to obtain solid volume in 94-1b bags. 
strengths at the early age periods; however, it decreases the rate of growth through time. This decrease ranges from 89 percent of $73^{\circ}$ growth rate to 38 percent of the $73^{\circ}$ growth rate with the majority of the decreases ranging between 40 percent and 60 percent.

7. On closer inspection of the 12 mixtures, i.e., 1, 2, 3, 4, 5, $6,7,8,13,14,15$, and 16 , it was found that at the $122^{\circ}$ F curing temperature for the sealed curing method, the estimated compressive strength relationships were parallel; however, this was not the case for the $73^{\circ} \mathrm{F}$ curing temperature data for the no WRA and conventional WRA categories. However, for the high-range WRA category, the response lines were parallel over the percent pozzolan replacement.

\section{Multilinear Compressive Strength Model}

8. After careful consideration of the individual compressive strength models, it became apparent that mixtures and percent pozzolan replacement could be consolidated by using the water/cementitious ratio (WCR) and the cementitious materials content by solid volume (CM) parameters. With this as an underlying goal, a model of the form

$$
f_{c}^{\prime}=K_{o}+K_{1} \ln (\text { age })+K_{2}(W C R)+K_{3}(C M)
$$

was estimated by curing type and temperature. The resulting models yielded $R^{2}$ values ranging from 77.4 percent to 90.19 percent of the total variance. The estimated models are described in Table C4.

\section{Compressive Strength and Water/Cementitious}

\section{Materials Ratio Relationship}

9. During analysis, inferences pertaining to the relationship between compressive strength and water/cementitious ratio were hypothesized. The hypothesis of a linear trend between $f_{c}^{\prime}$ and WCR was inferred. As a result of this hypothesis, the linear model

$$
f_{c}^{\prime}=C_{o}+C_{1}(W C R)
$$


Table $\mathrm{C} 4$

Consolidated Compressive Strength Models

by Curing Method and Temperature

\begin{tabular}{lcccc}
\hline $\begin{array}{c}\text { Curing } \\
\text { Method }\end{array}$ & $\begin{array}{c}\text { Curing } \\
\text { Temperature }\end{array}$ & $\frac{R^{2}}{2}$ & & $\mathrm{f}_{\mathrm{c}}^{\prime}=\mathrm{K}_{\mathrm{o}}+\mathrm{K}_{1} \mathrm{x}_{1}+\mathrm{K}_{2} \mathrm{x}_{2}+\mathrm{K}_{3} \mathrm{x}_{3}$ \\
Immersed & $73^{\circ} \mathrm{F}$ & 90.19 & $\mathrm{f}_{\mathrm{c}}^{\prime}=12,276+1,281 \mathrm{x}_{1}-22,125 \mathrm{x}_{2}-352 \mathrm{x}_{3}$ \\
Immersed & $122^{\circ} \mathrm{F}$ & $77.52 \mathrm{f}_{\mathrm{c}}^{\prime}=16,013+811 \mathrm{x}_{1}-24,398 \mathrm{x}_{2}-596 \mathrm{x}_{3}$ \\
Sealed & $73^{\circ} \mathrm{F}$ & $90.00 \mathrm{f}_{\mathrm{c}}^{\prime}=9,853+1,162 \mathrm{x}_{1}-16,692 \mathrm{x}_{2}-286 \mathrm{x}_{3}$ \\
Sealed & $122^{\circ} \mathrm{F}$ & $77.40 \mathrm{f}_{\mathrm{c}}^{\prime}=12,848+630 \mathrm{x}_{1}-18,682 \mathrm{x}_{2}-303 \mathrm{x}_{3}$
\end{tabular}

$$
\text { Note: } \begin{aligned}
\mathrm{x}_{1} & =\ln (\text { age) } \\
\mathrm{x}_{2} & =\mathrm{WC} \\
\mathrm{x}_{3} & =\mathrm{CM}
\end{aligned}
$$

was evaluated at each age and temperature. The results of this modeling effort are displayed in Table C5.

\section{Table C5}

\begin{tabular}{|c|c|c|c|}
\hline Age & Temperature & $\mathrm{R}^{2}$ & Model* \\
\hline \multirow[t]{2}{*}{3 days } & $73^{\circ} \mathrm{F}$ & 63.42 & $f_{c}^{\prime}=8,777-14,113 x_{1}$ \\
\hline & $122^{\circ} \mathrm{F}$ & 73.77 & $f_{c}^{\prime}=10,753-16,118 x_{1}$ \\
\hline \multirow[t]{2}{*}{7 days } & $73^{\circ} \mathrm{F}$ & 62.92 & $\mathrm{f}_{c}^{\prime}=12,027-18,384 \mathrm{x}_{1}$ \\
\hline & $122^{\circ} \mathrm{F}$ & 82.77 & $f_{c}^{\prime}=13,229-18,189 x_{1}$ \\
\hline \multirow[t]{2}{*}{28 days } & $73^{\circ} \mathrm{F}$ & 77.57 & $f_{c}^{\prime}=13,409-17,669 x_{1}$ \\
\hline & $122^{\circ} \mathrm{F}$ & 81.04 & $f_{c}^{\prime}=13,942-16,891 x_{1}$ \\
\hline \multirow[t]{2}{*}{90 days } & $73^{\circ} \mathrm{F}$ & 78.33 & $\mathrm{f}_{c}^{\prime}=14,331-16,091 \mathrm{x}_{1}$ \\
\hline & $122^{\circ} \mathrm{F}$ & 75.93 & $\mathrm{f}_{c}^{\prime}=14,902-18,386 \mathrm{x}_{1}$ \\
\hline \multirow[t]{2}{*}{365 days } & $73^{\circ} \mathrm{F}$ & 74.54 & $\mathrm{f}_{\mathrm{c}}^{\prime}=15,742-16,492 \mathrm{x}_{1}$ \\
\hline & $122^{\circ} \mathrm{F}$ & 71.05 & $\mathrm{f}_{c}^{\prime}=15,194-18,680 \mathrm{x}_{1}$ \\
\hline \multirow[t]{2}{*}{730 days } & $73^{\circ} \mathrm{F}$ & 56.26 & $\mathrm{f}_{c}^{\prime}=14,706-13,430 \mathrm{x}_{1}$ \\
\hline & $122^{\circ} \mathrm{F}$ & 25,68 & $\mathrm{f}_{\mathrm{c}}^{\prime}=15,313-17,257 \mathrm{x}_{1}$ \\
\hline
\end{tabular}

\section{Linear Degradation Functions}

$$
\mathrm{f}_{\mathrm{c}}^{\prime}=\mathrm{C}_{\mathrm{o}}+\mathrm{C}_{1}(\mathrm{WCR})
$$

* $\mathrm{x}_{1}$ : Water/cementitious materials ratio (WRC). 
10. From this table, it is seen that the linear trend for the age periods up to 365 days will explain from 62.92 percent to 82.77 percent of the total variance; however, during the 730-day testing period, the $\mathrm{R}^{2}$ values sharply decreased. Therefore, the linear degradation function seems to fit well up to 1 year; however, after 1 year the assumption of a linear degradation function does not appear to be valid.

\section{Summary}

11. The modeling activities in this experiment have indicated that compressive strength gains are linearly related with 1 n(age), and that this relationship could be used to predict compressive strength values with confidence within the 2-year age period of Phase I tests. Furthermore, this relationship indicates that concrete with the same cementitious material contents will yield parallel response curves over increased concentrations of percent pozzolan replacement.

12. In order to transcend individual material types and differences in percent pozzolan replacement, a multiple linear model of the form

$$
f_{c}^{\prime}=K_{o}+K_{1} \ln (\text { days })+K_{2}(W C R)+K_{3}(C M)
$$

was developed for each individual curing type (immersed or sealed) and curing temperature $\left(73^{\circ} \mathrm{F}\right.$ and $\left.122^{\circ} \mathrm{F}\right)$. The results of this modeling activity exhibited multiple linear models which adequately describe the compressive strengths within these four categories.

13. Also, the relationship between water/cementitious materials ratio (WCR) and compressive strength $\left(f_{c}^{\prime}\right)$ was investigated and it was found that this relationship could be adequately described by the linear degradation function

$$
f_{C}^{\prime}=C_{o}+C_{1}(W C R)
$$

